\author{
Mon ograph \\ urn:1sid:zoobank.org:pub:C4C4D130-1EA7-48AA-A664-391DBC59C484
}

\title{
The Indo-Pacific Amalda (Neogastropoda, Olivoidea, Ancillariidae) revisited with molecular data, with special emphasis on New Caledonia
}

\author{
Yuri I. KANTOR ${ }^{1, *}$, Magalie CASTELIN ${ }^{2}$, Alexander FEDOSOV ${ }^{3} \&$ Philippe BOUCHET $^{4}$ \\ ${ }^{1,3}$ A.N. Severtsov Institute of Ecology and Evolution, Russian Academy of Sciences, \\ Leninski Prospect 33, 119071 Moscow. \\ ${ }^{2,4}$ Institut de Systématique, Évolution, Biodiversité, ISYEB, UMR7205 (CNRS, EPHE, MNHN, \\ UPMC), Muséum national d'histoire naturelle, Sorbonne Universités, 43 Rue Cuvier, \\ 75231 Paris Cedex 05, France. \\ ${ }^{*}$ Corresponding author: kantor.yuri1956@gmail.com \\ ${ }^{2}$ Email: magalie.castelin@mnhn.fr \\ ${ }^{3}$ Email: fedosovalexander@gmail.com \\ ${ }^{4}$ Email: philippe.bouchet@mnhn.fr \\ ${ }^{1}$ urn:1sid:zoobank.org:author:48F89A50-4CAC-4143-9D8B-73BA82735EC9
${ }^{2}$ urn:1sid:zoobank.org:author:9464EC90-738D-4795-AAD2-9C6D0FA2F29D
${ }^{3}$ urn:1sid:zoobank.org:author:40BCE11C-D138-4525-A7BB-97F594041BCE
${ }^{4}$ urn:1sid:zoobank.org:author:FC9098A4-8374-4A9A-AD34-475E3AAF963A
}

\begin{abstract}
In the ancillariid genus Amalda, the shell is character rich and 96 described species are currently treated as valid. Based on shell morphology, several subspecies have been recognized within Amalda hilgendorfi, with a combined range extending at depths of 150-750 m from Japan to the South-West Pacific. A molecular analysis of 78 specimens from throughout this range shows both a weak geographical structuring and evidence of gene flow at the regional scale. We conclude that recognition of subspecies (richeri Kilburn \& Bouchet, 1988, herlaari van Pel, 1989, and vezzaroi Cossignani, 2015) within A. hilgendorfi is not justified. By contrast, hilgendorfi-like specimens from the Mozambique Channel and New Caledonia are molecularly segregated, and so are here described as new, as Amalda miriky sp. nov. and A. cacao sp. nov., respectively. The New Caledonia Amalda montrouzieri complex is shown to include at least three molecularly separable species, including A. allaryi and A. alabaster sp. nov. Molecular data also confirm the validity of the New Caledonia endemics Amalda aureomarginata, A. fuscolingua, A. bellonarum, and A. coriolis. The existence of narrow range endemics suggests that the species limits of Amalda with broad distributions, extending, e.g., from Japan to Taiwan (A. hinomotoensis) or even Indonesia, the Strait of Malacca, Vietnam and the China Sea (A. mamillata) should be taken with caution.
\end{abstract}

Keywords. Amalda hilgendorfi species complex, deep-water Amalda, Cox1, integrative taxonomy.

Kantor Y.I., Castelin M., Fedosov A. \& Bouchet P. 2020. The Indo-Pacific Amalda (Neogastropoda, Olivoidea, Ancillariidae) revisited with molecular data, with special emphasis on New Caledonia. European Journal of Taxonomy 706: 1-59. https://doi.org/10.5852/ejt.2020.706 


\section{Introduction}

The genus Amalda H. Adams \& A. Adams, 1853 is broadly distributed in the tropical waters of the World Ocean from the intertidal to several hundred meters. Presently, the genus includes 96 Recent species, classified in seven nominal subgenera (Kantor et al. 2017), some of them at times treated as full genera. The genus has been reviewed on conchological grounds in a series of papers by Gratecap $(2012,2014$, 2016a, 2016b). The type species Amalda tankervillii (Swainson, 1825) inhabits the tropical western Atlantic and two more species occur in the tropical and subtropical Atlantic (Rosenberg 2009); the remaining ones are Indo-Pacific, with a particularly rich fauna in Australia (32 species: Gratecap 2016a) and the Indo-West Pacific (19 species: Gratecap 2016b). However, until the recent paper by Gemmel et al. (2020), Amalda has remained practically overlooked from the molecular point of view, with sequences of only 5 species deposited in GenBank, essentially originating from the molecular phylogeny of the superfamily Olivoidea by Kantor et al. (2017). Gemmel et al. (2020) presented a molecular phylogeny based on the entire mitogenome and long nuclear rRNA gene cassette data, targeting primarily New Zealand species of Amalda. These included species attributed to the subgenera Baryspira P. Fischer, 1883 (including the type species A. australis (G.B. Sowerby I, 1830) and Gracilispira Olsson, 1956 (including the type species $A$. novaezelandiae (G.B. Sowerby II, 1859); as well as six Indo-Pacific species, mostly based on the MNHN collections that also form the basis of the present paper.

The New Caledonian Amalda were treated by Kilburn \& Bouchet (1988) who described four new species and one new subspecies in addition to the previously known Amalda montrouzieri (Souverbie, 1860); three additional species were described by Bozzetti (2007) and Cossignani (2013). With the exception of $A$. montrouzieri and A. hilgendorfi, all are endemic to New Caledonia. Since the paper by Kilburn \& Bouchet, a considerable amount of material has been collected by the expeditions organized by MNHN with IRD and other partners in different parts of the tropical Indo-Pacific, including New Caledonia. The major goal of the present work is to revise the New Caledonian fauna of Amalda based on molecular data. For comparative purposes, material from other regions of Indo-Pacific was also sequenced.

\section{Material and methods}

\section{Material}

Specimens, including material suitable for sequencing was collected during the Indo-West Pacific Tropical Dee-Sea Benthos expeditions: MIRIKY, INHACA 2011 in Madagascar and Mozambique; TERRASSES, EXBODI, NORFOLK 2, KANACONO (https://doi.org/10.17600/16003900), EBISCO, KANADEEP 1 (https://doi.org/10.17600/17003800), and CONCALIS in New Caledonia; NanHai 2014 and ZhongSha 2015 in the South China Sea; PANGLAO 2005 in the Philippines; SALOMON 2 (https://doi.org/10.17600/4100090), SALOMONBOA 3 (https://doi.org/10.17600/7100070) in the Solomon Islands; BIOPAPUA, PAPUA NIUGINI, MADEEP, KAVIENG in Papua New Guinea. For comparative purposes, material represented by empty shells and specimens not suitable for sequencing was also examined. The list of this material is provided in the 'Material Examined' section of each species. Additional material from other sources, mostly collected by fishermen or divers, including WESTERN AUSTRALIA 2011 was also examined and, where possible, sequenced.

Until 2012, live specimens for molecular analysis were anaesthetized with an isotonic solution of $\mathrm{MgCl}_{2}$ and fixed in $96 \%$ ethanol. Specimens collected during later expeditions were processed with a microwave oven (Galindo et al. 2014): the living molluscs in small volumes of sea water were exposed to microwaves for 10-60 s, depending on specimen size. Bodies were immediately removed from shells and dropped in $96 \%$ ethanol. Specimens are registered in the MNHN collection and sequences are deposited in BOLD (Barcode of Life Datasystem) and GenBank (Table 1).

The sequences of Coxl fragments of five species of New Zealand Amalda representing the subgenera Baryspira and Gracilispira were kindly made available to us by M. Gemmel (Massey University, Palmerston North, New Zealand) and are included in our analysis for comparative purposes. 
KANTOR Yu.I. et al., The Indo-Pacific Amalda (Neogastropoda, Olivoidea, Ancillariidae)

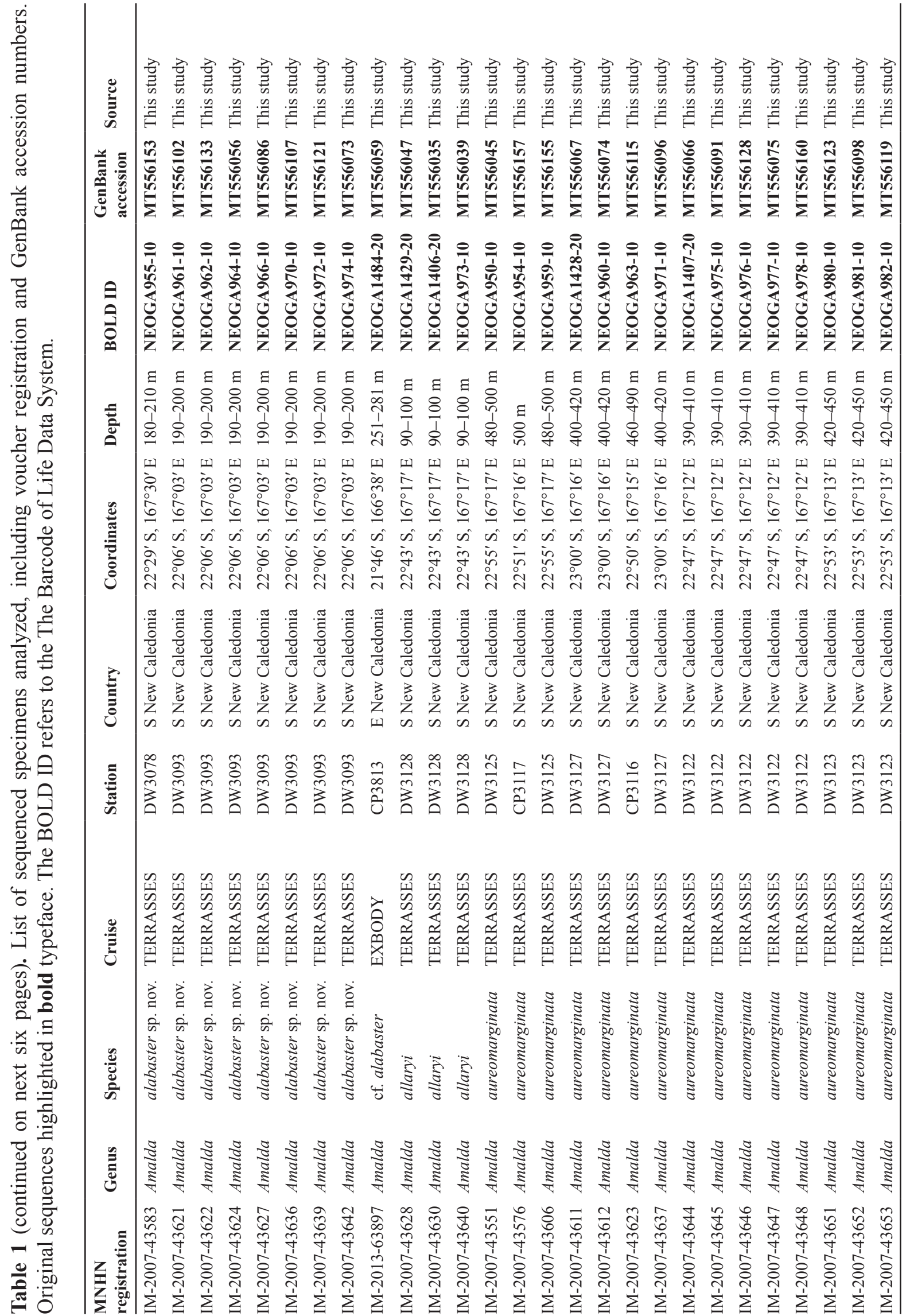




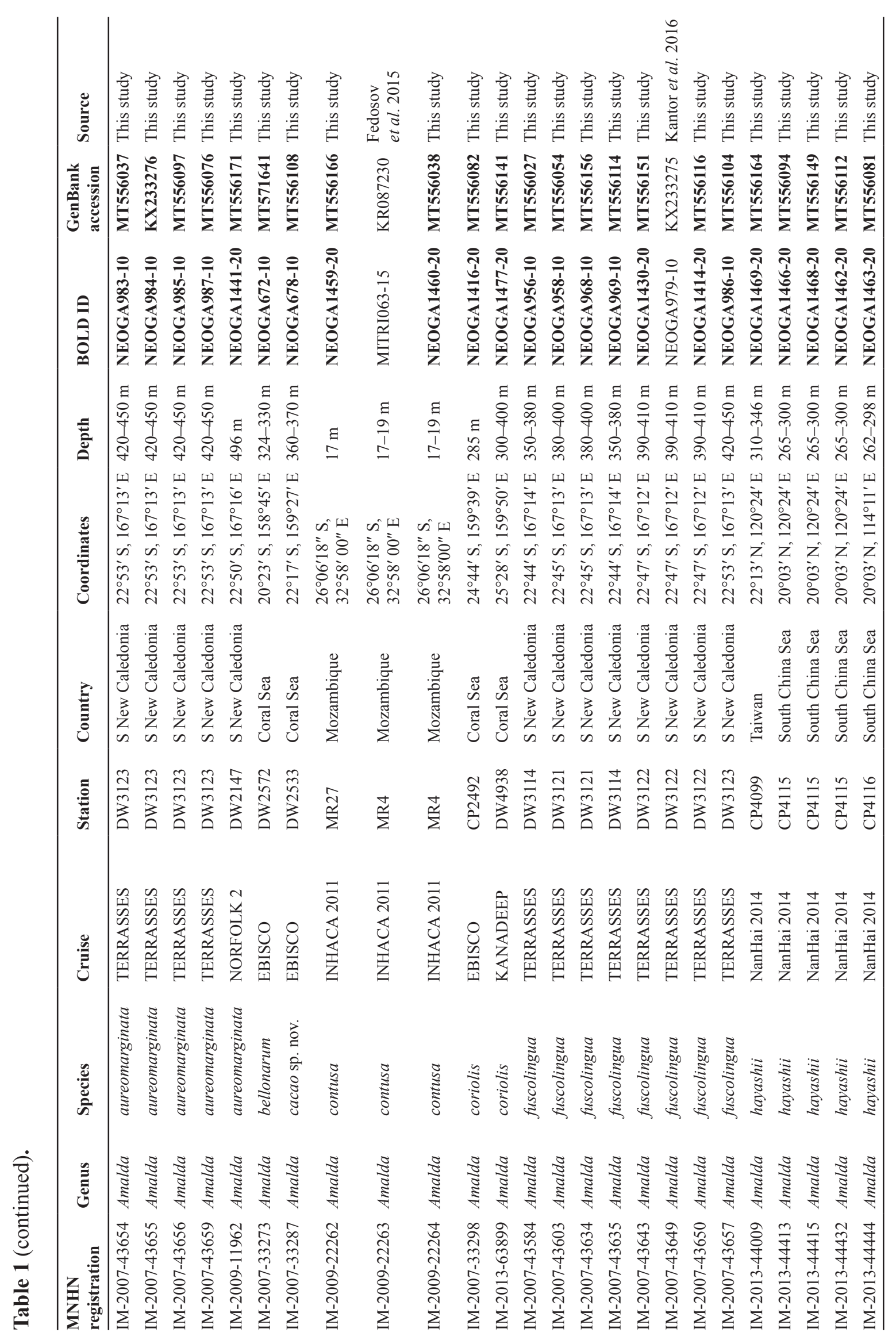


KANTOR Yu.I. et al., The Indo-Pacific Amalda (Neogastropoda, Olivoidea, Ancillariidae)

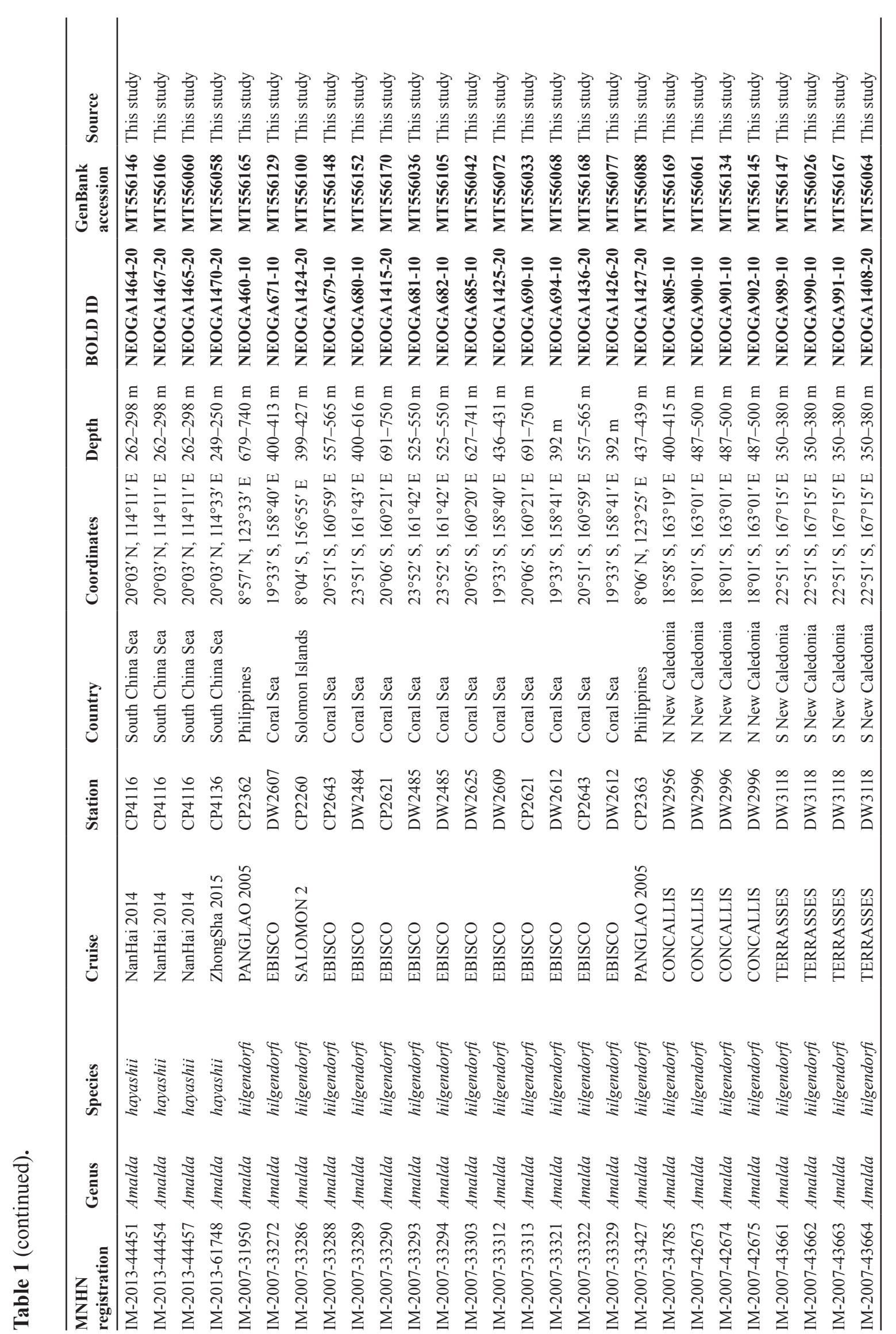




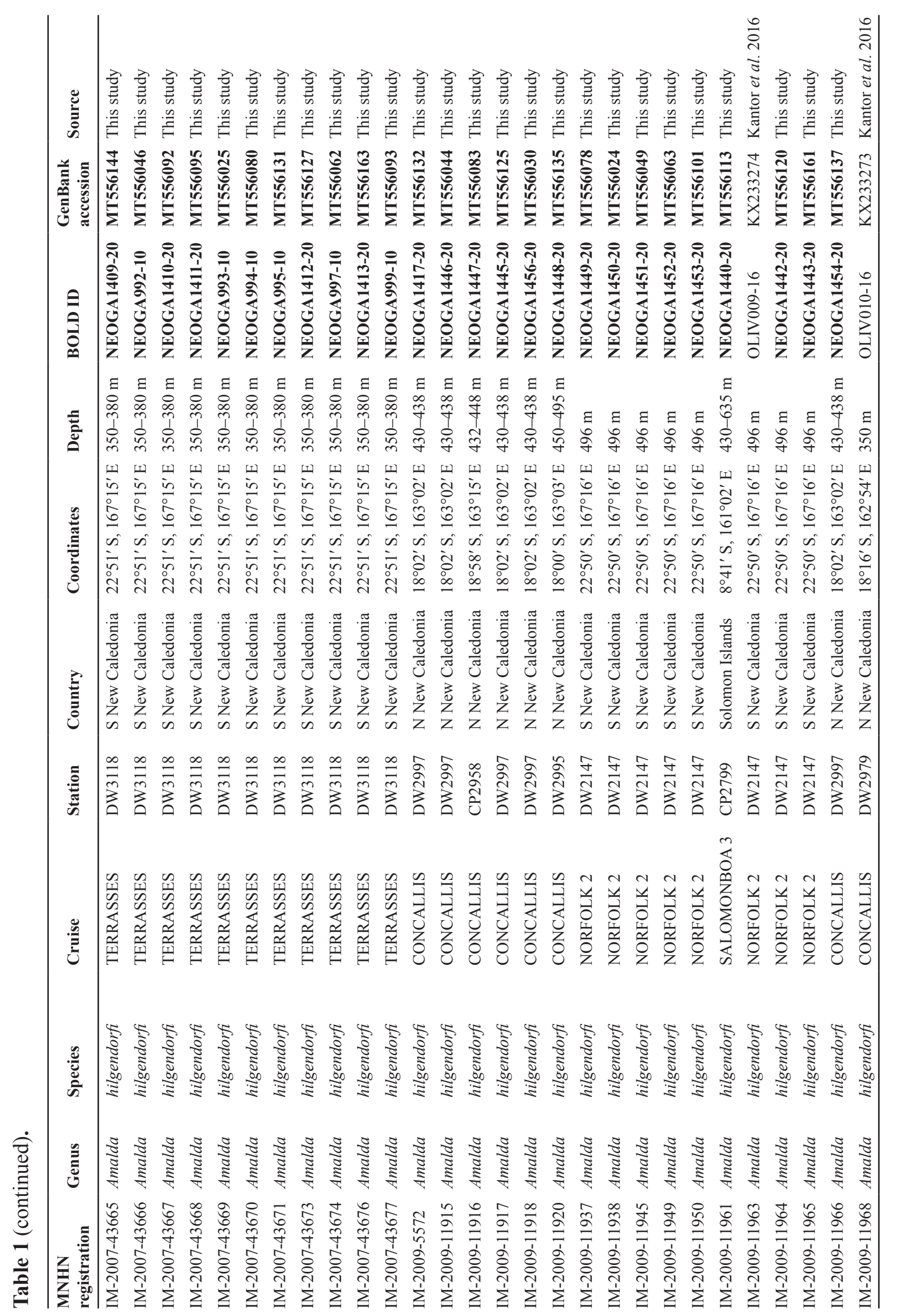


KANTOR Yu.I. et al., The Indo-Pacific Amalda (Neogastropoda, Olivoidea, Ancillariidae)

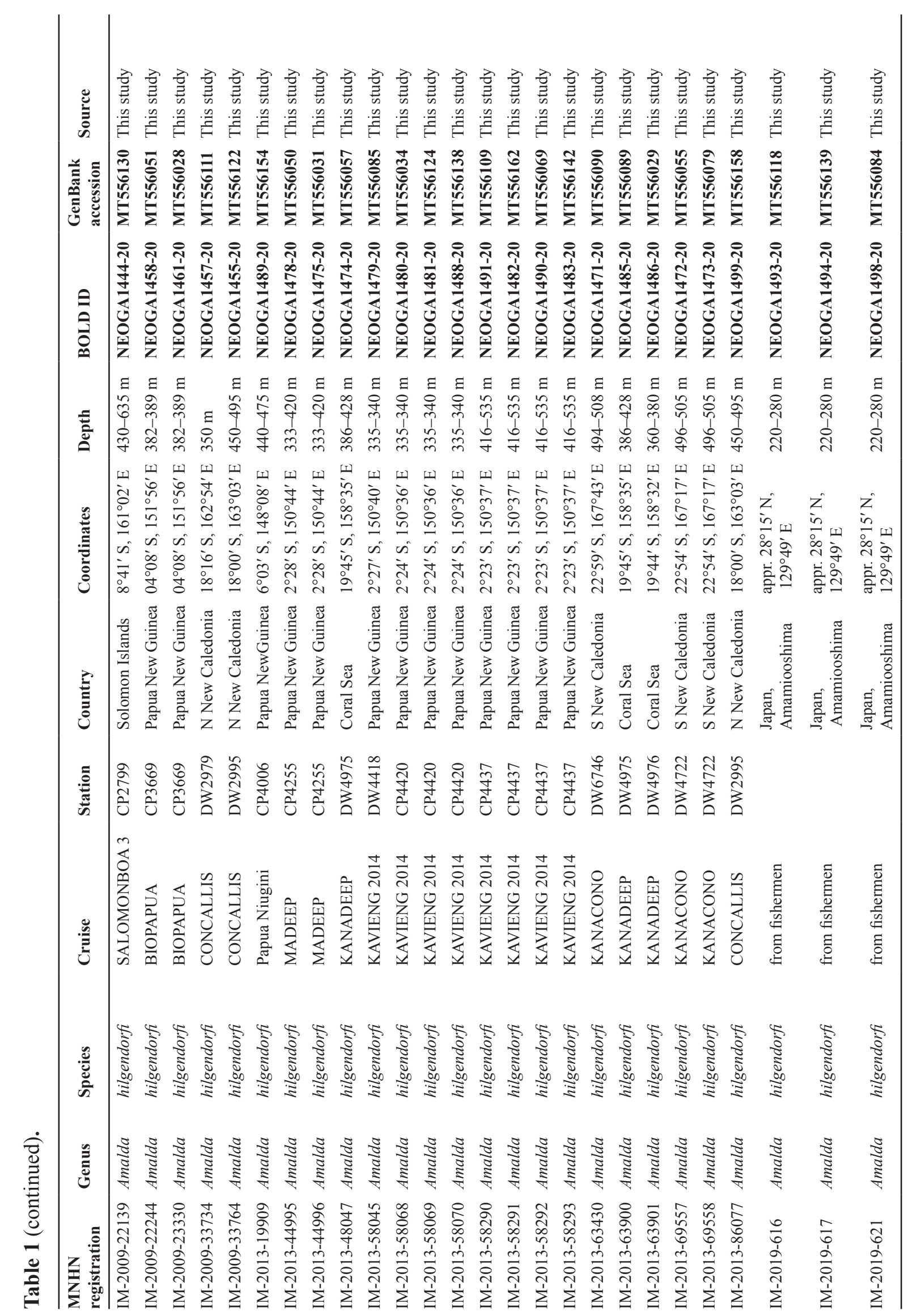




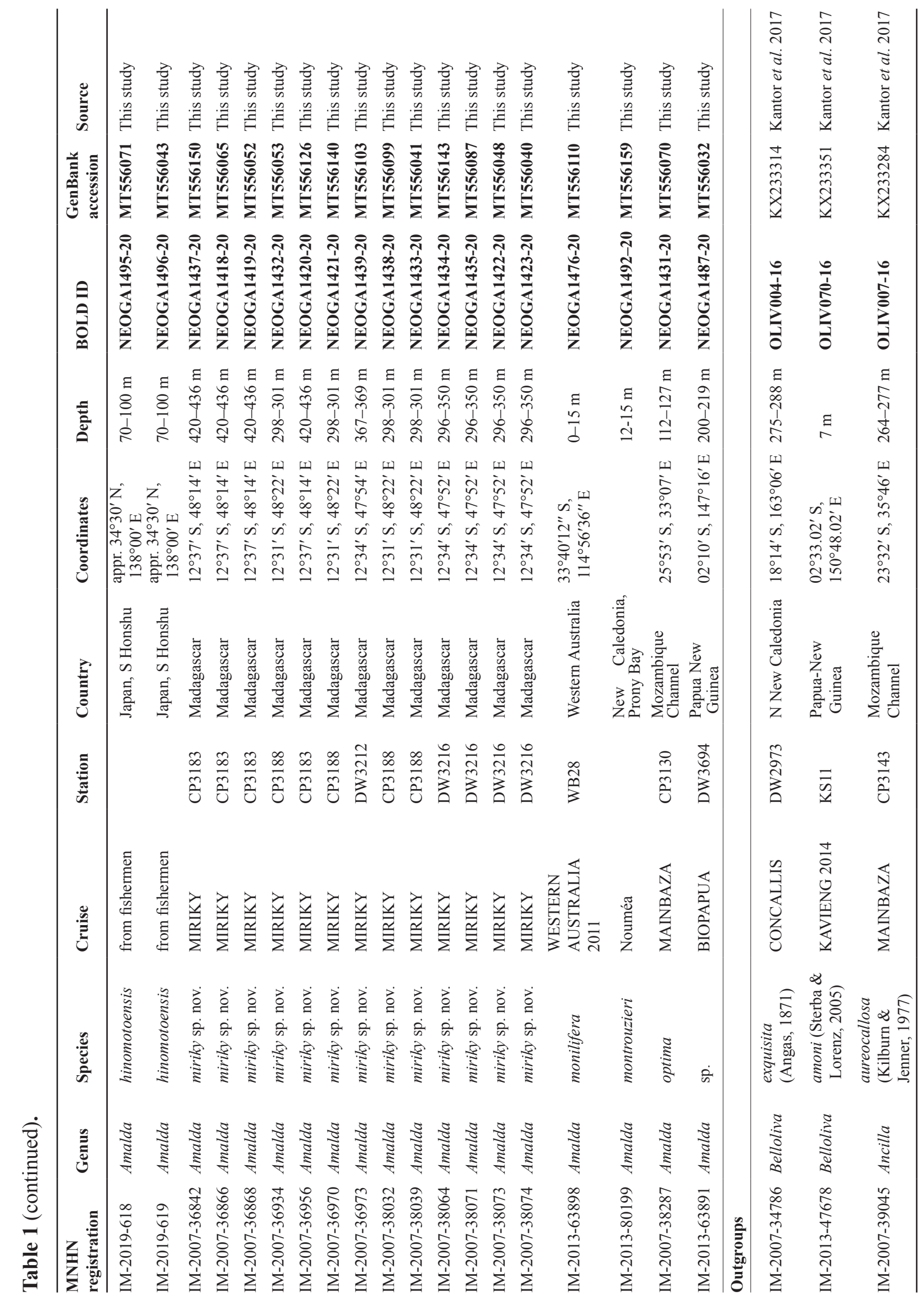




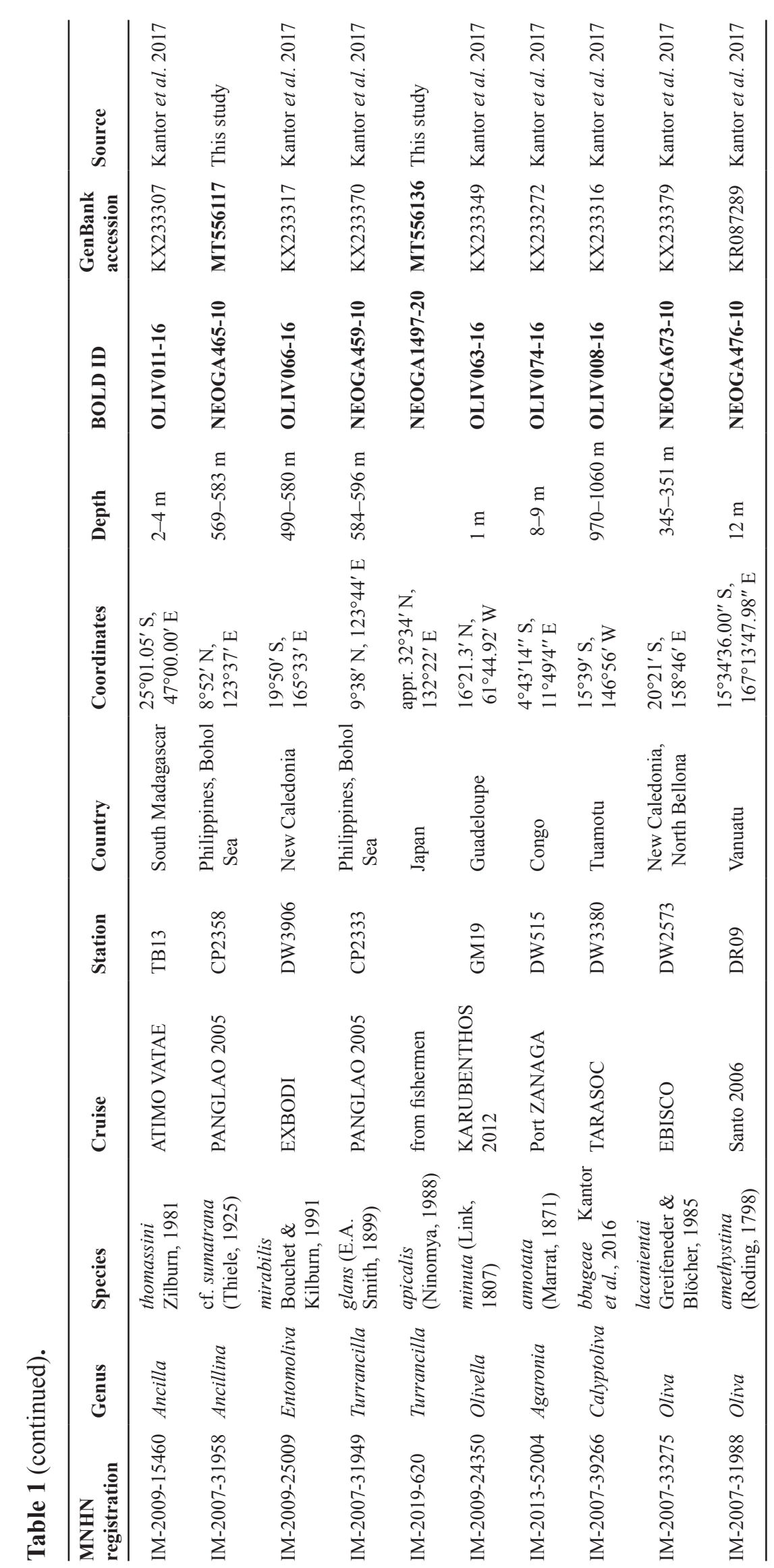




\section{Sequencing and phylogenetic reconstruction}

The total genomic DNA was extracted from muscle tissue with the semi-automated ABI PRISMTM 6100 Nucleic Acid Prep Station following the manufacturer's instructions. A fragment of $650 \mathrm{bp}$ of the Cox1 mitochondrial gene was amplified using universal primers LCOI1490 and HCO2198 (Folmer et al. 1994). DNA amplification was performed in 25-mL PCR reactions, containing approximately $3 \mathrm{ng}$ of template DNA, $2.5 \mathrm{~mm}$ magnesium chloride $\left(\mathrm{MgCl}_{2}\right), 0.26 \mathrm{~mm}$ of each nucleotide, $0.3 \mathrm{mM}$ of each primer, 5\% dimethylsulphoxide (DMSO) and 1.5 units of QBIOTAQ polymerase (MP Biomedicals). Amplification products were generated by an initial denaturation step of 4 min at $94^{\circ} \mathrm{C}$ followed by 30 cycles of denaturation at $94^{\circ} \mathrm{C}$ for $30 \mathrm{~s}$, annealing at $48^{\circ} \mathrm{C}$ for $40 \mathrm{~s}$ and extension at $72^{\circ} \mathrm{C}$ for $1 \mathrm{~min}$. PCR products were sequenced in both directions to ensure the accuracy of base calls.

Sequences were aligned using the FFT-NS-I strategy in MAFFT ver. 7 (Katoh \& Toh 2010; Katoh et al. 2019; http://mafft.cbrc.jp/alignment/server/). We used BioEdit ver. 7.0.5.3 (Hall 1999) to check for poorly aligned sites and MEGA ver. 5.05 (Tamura et al. 2011) to translate protein-coding sequences to screen for premature stop codons. Phylogenetic reconstructions were estimated using Bayesian Inference (BI) and Maximum Likelihood (ML). All nucleotide sites were conserved and three partitions corresponding to first, second and third codon positions were analyzed independently. A generalized time reversible model with a gamma law ( $\mathrm{G}$, four categories) and a proportion of invariants (I) was selected for both BI and ML analyses as it is the most inclusive model of nucleotide evolution. BI analyses were performed in two parallel runs in MrBayes (Huelsenbeck et al. 2001) and consisted of six Markov chains and 10000000 generations with default number of chain swaps and sampling frequency of one tree in each 500 generations. A chain temperature of 0.02 was used in all analyses. The convergence of each analysis was checked using Tracer ver. 1.4.1 (Rambaut et al. 2014); the two runs were considered converged if all effective sample size (ESS) values exceeded 200. Consensus trees were calculated after discarding the first 25\% trees as burn-in. Best-scoring ML trees were estimated using RAxML (Stamatakis 2014). One hundred independent searches, each starting from distinct random trees, were conducted. The robustness of nodes was assessed using rapid bootstrapping with 1000 bootstrap replicates. All analyses were implemented in the Cipres Science Gateway (https://www.phylo.org/) portal ver. 3.3. (Miller et al. 2010), using MrBayes ver. 3.2.6 on XSEDE and RAXML-HPC2 on XSEDE (ver. 8.1.11). Species delimitation analyses were conducted using the Automatic Barcode Gap Discovery (ABGD) method of Puillandre et al. (2012) that uses detection of the 'barcode gap' in the distribution of genetic pairwise distances. The ABGD method was implemented based on all available Coxl sequences and using the online version of the program (https://bioinfo.mnhn.fr/abi/public/abgd/abgdweb.html) with default parameters.

Nodes with Bootstraps values (B) lower than $70 \%$ and Posterior Probabilities (PP) lower than 0.90 are considered non-supported; B-values between 70 to 90 and PP-values between 0.90 to 0.95 will be regarded as moderately supported and $\mathrm{B}>90$ and $\mathrm{PP}>0.95$ shall be treated as highly supported.

To visualize the relationships between haplotypes and their geographic distribution of the widely distributed A. hilgendorfi (von Martens, 1897), a Median-Joining Network (MJN) was constructed using the program NETWORK ver. 5.0.1.0 (Bandelt et al. 1999) with equal weights for variable sites $($ epsilon $=0)$ and connection cost calculation method. To delete superfluous median vectors and links that are not contained in the shortest tree, a post-processing maximum parsimony calculation was run.

Unless stated otherwise, all illustrated specimens with MNHN registration numbers were sequenced.

\section{Morphological studies}

The terminology of shell characters follows Kantor et al. (2017). The primary spire callus covers most of the spire, including at least part of the protoconch, leaving in most cases only the first protoconch whorl exposed. Therefore, for comparative purposes, we measured only the diameter of the first whorl, following the method described by Bouchet $\&$ Kantor (2004). The radula was examined when available. It was cleaned in dilute bleach, mounted on glass cover slips and air dried; the cover slips were glued to aluminum stubs, then coated with gold and studied on scanning electron microscope TeScan TS5130MM in the Institute of Ecology and Evolution of the Russian Academy of Sciences (IEE RAS). 


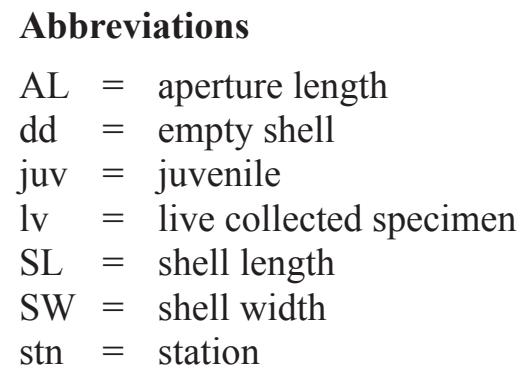

\section{Repositories}

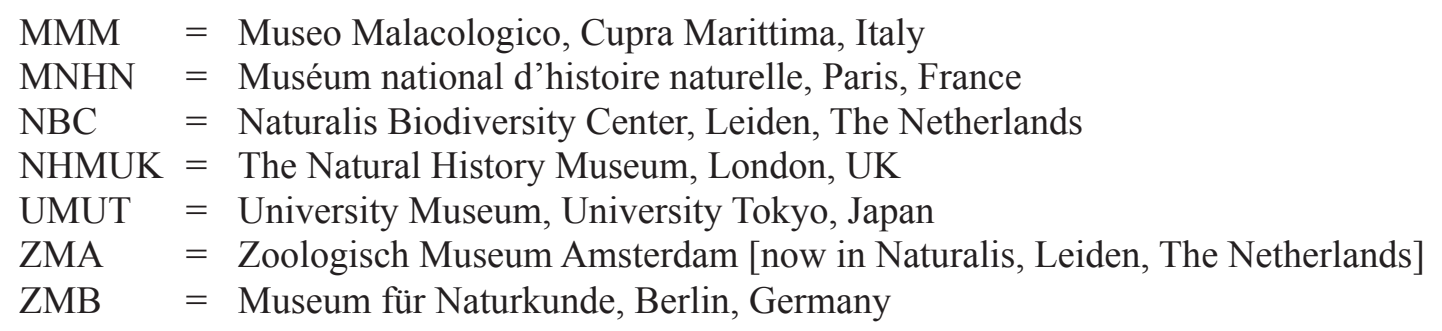

\section{Results}

\section{Molecular analysis and species delimitation}

The trees obtained with ML and BI analyses have similar topologies, with a few differences in the robustness of some nodes (Fig. 1). The genus Amalda is not supported, either in the ML tree or in the BI tree (Posterior Probability, $\mathrm{PP}=0.83$ ).

The ABGD method estimated seven a priori thresholds. Extreme threshold values led to partitions where each of the 64 Coxl haplotypes of Amalda (not taking into account outgroups) was considered as a different Primary Species Hypothesis (PSH), or conversely where almost all haplotypes were considered as a single PSH. Five intermediate a priori thresholds led to five partitions with 38, 38, 33, 31 and 22 PSHs detected within Amalda. Vouchers of the four inferred PSHs (A. australis + A. depressa (G.B.Sowerby II, 1839), A. novaezelandiae, A. mucronata (G.B.Sowerby I, 1830), A. benthicola (Dell, 1956)) in the partition scheme with 22 PSHs were not available for study. Amalda australis and A. depressa were not recognized as separate species in any of the obtained partition schemes, except the one comprising 64 PSHs. An examination of the shell morphology supported only 17 out of the remaining 18 PSHs. Indeed, two closely related PSHs, hereafter referred to as A. miriky sp. nov., showed no difference in shell morphology. Populations within this species are expected to be spatially structured because of the high level of habitat fragmentation and the reduced dispersal ability of the larvae as inferred from protoconch morphology. Consequently, we can expect that ABGD may split the dataset at the population level rather than at the species level. The 17 PSHs supported by both the shell morphology and the genetic clustering were hereafter treated as Secondary Species Hypotheses (SSH).

Based on these $17 \mathrm{SSHs}$, an examination of the published data and a comparison with the type specimens allowed to apply species names to 12 of them (Fig. 1). Among the remaining five SSHs, two are represented by multiple sequenced specimens and are described herein as new species, A. miriky sp. nov. and $A$. alabaster sp. nov. Three more are represented by a single sequenced specimen. Specimen MNHN IM-2007-33287 is very distinct morphologically and several additional, not sequenced specimens are present in our material. A comparison with other known species of Amalda leaves no doubt that these correspond to a new species, which is described here as $A$. cacao sp. nov. Sister to it is a single, seemingly subadult, specimen MNHN IM-2013-63891 from Papua New Guinea, and no comparable additional specimens are present in the available material. Although it definitely represents a separate species, we abstain from its description for the moment (see below for discussion). Finally, 


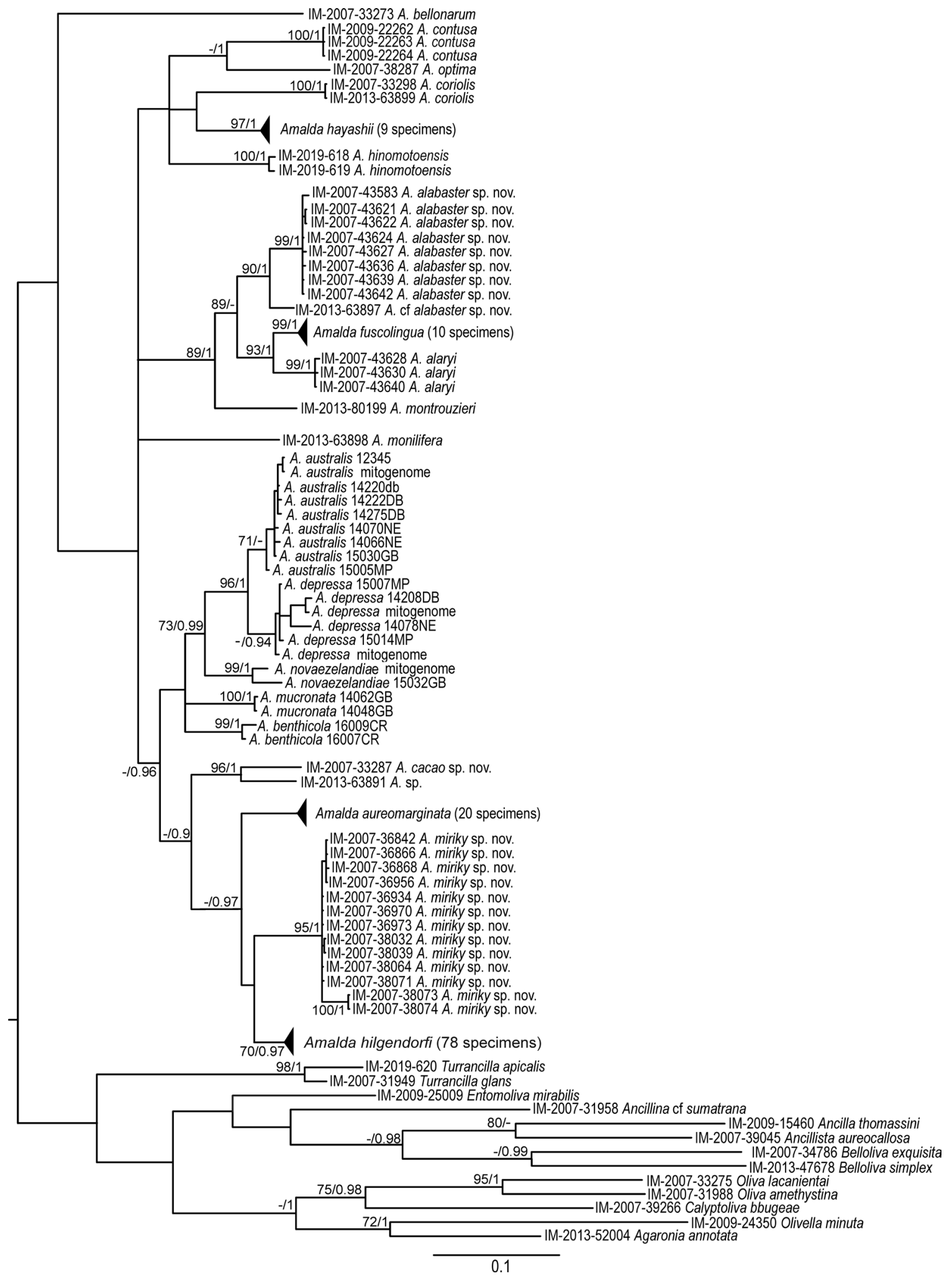

Fig. 1. Bayesian tree (MrBayes) for the Coxl gene. Bootstrap supports $(\geq 70)$ and posterior probabilities $(>0.90)$ values are shown for each supported node. The unit for the scale is "substitutions/site". The clades of Amalda hayashii Ninomiya, 1988, A. fuscolingua Kilburn \& Bouchet, 1988 and A. aureomarginata Kilburn \& Bouchet, 1988 containing multiple specimens with minimal genetic distances are collapsed. The clade of A. hilgendorfi (von Martens, 1897) is collapsed and shown on Fig. 2. 
the specimen MNHN IM-2013-63897 is sister to A. alabaster sp. nov., with a high support both in ML and BI trees. Morphologically, it is similar to A. alabaster sp. nov. Since no additional material suitable for sequencing is available at the moment we also do not provide a formal description (see below).

The largest clade, very heterogeneous both molecularly and morphologically, is represented in our material by 78 sequenced specimens from different regions of the West Pacific. It is highly supported in the $\mathrm{BI}$ tree $(\mathrm{PP}=0.97)$, and moderately supported in the $\mathrm{ML}$ tree $(\mathrm{B}=70)$. Among these specimens, three were collected in Japan. They are similar to the type of Ancilla hilgendorfi and we applied this name to that clade.

The haplotypes network obtained from Coxl sequences showed high genetic disparity, with a total of thirty haplotypes separated by high number of mutation steps (Fig. 3). The haplotypes network on the other hand displays a pronounced geographic structure (with 29 of 30 haplotypes represented in only one major region). A striking pattern here is the presence of two highly divergent assemblages of haplotypes at same sampling sites around Île des Pins (showed in yellow on Fig. 3), and huge disparity of haplotypes in specimens from Papua New Guinea (Bismarck Sea) (recovered in five unrelated clusters, purple on Fig. 3). One distinctive and large group (highlighted by a green rectangle on Fig. 3) included individuals exclusively sampled from New Caledonia EEZ, except for one specimen from Papua New Guinea.

While the terminal groups (SSH) are well supported, at least in the Bayesian analysis, the deeper nodes are mostly not resolved, a situation typical with a single genetic marker. Two groupings are however statistically supported: a clade uniting A. alabaster sp. nov., A. fuscolingua, A. allaryi and A. montrouzieri, and (only in BA) a second one including all remaining New Caledonian (except $A$. bellonarum) and New Zealand species.

\title{
Systematic descriptions
}

\author{
Gastropoda Cuvier, 1795 \\ Subclass Caenogastropoda Cox, 1960 \\ Order Neogastropoda Wenz, 1938 \\ Family Ancillariidae Swainson, 1840
}

Genus Amalda H. Adams \& A. Adams, 1853

\section{Type species}

Ancillaria tankervillii Swainson, 1825, by subsequent designation by Cossmann (1899).

\section{Remarks}

Amalda tankervillii occurs in Venezuela in shallow water (6 to $70 \mathrm{~m}$ ) and is conchologically quite different from the other species included in the genus (Fig. 4M). Neither its anatomy nor the molecular data have been examined. Based on shell characters, Voskuil (1991) compared Ancillaria tankervillii with species of Eburna Lamarck, 1801 and concluded that Amalda s. str. should be considered a subgenus of Eburna, while the Indo-Pacific species of Amalda probably belong to a separate genus Baryspira P. Fischer, 1883. Although A. tankervillii is indeed somewhat different from Indo-Pacific species in being thin, broadly oval, with a large inflated last whorl and a very low spire, in the absence of molecular and anatomical data the opinion of Voskuil (1991) remains speculative. Herein, we follow the generally accepted taxonomic concept of Amalda and do not attempt to revise its generic/subgeneric structure, which will require a much broader molecular taxon sampling than is currently available, as well, as sequencing additional genetic markers. 
Amalda hilgendorfi (von Martens, 1897)

Figs 2-4, 5-6, 7A-G, 8I-J

Ancillaria hilgendorfi von Martens, 1897: 167, pl. 16 figs 26-27.

Amalda hilgendorfi richeri Kilburn \& Bouchet, 1988: 285-287, figs 18-22 [not figs 23-24=Amalda cacao sp. nov.].

Amalda vernedei herlaari van Pel, 1989: 14, figs 1-3.

Amalda hilgendorfi vezzaroi Cossignani, 2015: 24-25, text figures.

Baryspira hilgendorf - Kira 1962: 208, pl. 71 fig. 1. — Kuroda et al. 1971: 300 [Japanese text], 196 [English text], pl. 54. fig. 1.

Amalda aureomarginata Northern New Caledonia form - Kilburn \& Bouchet 1988: 284, Fig. 13.

Amalda aureomarginata Chesterfield form - Kilburn \& Bouchet 1988: 284, figs 14-17.

?Amalda (Alcospira) hilgendorfi - Ninomiya 1990: pl. 2 fig. 5.

Amalda hilgendorfi - Okutani 2000: 523, pl. 260 fig. 2 (erroneously labelled A. hayashii on the plate) [not pl. 260 fig. $3=$ A. hayashii]. — Gratecap 2016b: 4, 12, figs 3-4. — Tsuchida 2017: 995, pl. 288 fig. 3.

Amalda vernedei herlaari - Poppe 2008: pl. 546, figs 7-9.

Amalda hilgendorfi richeri - Gratecap 2014 (part): 14, 19, figs 19-23 [not figs 24-25=Amalda cacao sp. nov.]

\section{Type material}

JAPAN • Holotype of Ancillaria hilgendorfi; ZMB 31632.

NEW CALEDONIA • Holotype of Amalda hilgendorfi richeri; North of New Caledonia, Grand Passage; $18^{\circ} 57^{\prime} \mathrm{S}, 163^{\circ} 14^{\prime} \mathrm{E} ; 480 \mathrm{~m}$ deep; MNHN IM-2000-1378.

ARAFURA SEA • Holotype of Amalda vernedei herlaari; Arafura Sea; 150 fathoms [270 m]; formerly ZMA Moll. no. 3.88.040, now NBC.

PHILIPPINES • Holotype of Amalda hilgendorfi vezzaroi; Philippines, Aliguay island; MMM.

\section{Description}

SHELL. Variable, narrowly to broadly fusiform with high, acuminate spire; thin to thick microshagreened primary callus impressed at suture, forming distinct to very distinct, obtuse keel above suture. Protoconch exposed, medium large $(\mathrm{n}=2$, first whorl diameter $0.75-0.92 \mathrm{~mm})$, border with teleoconch indistinct. Secondary callus very thin to distinct, tongue-shaped, broadening in middle part and rounded adapically, extending on last three whorls, seemingly less shagreened than primary callus. Plication plate with 2-7 weak ridges, sometimes nearly obsolete. Olivoid groove from narrow and distinct to broad and shallow or nearly obsolete, labral tooth distinct, obtuse. Upper anterior band usually thickened, sometimes heavily. Colour variable, from pale yellowish to brown, olivoid band always lighter than body whorl cloak, anterior band the darkest anterior zone of shell, plication plate usually nearly white, primary callus bordered by lighter narrow band (or line). Height to $81 \mathrm{~mm}$, exceptionally up to $98 \mathrm{~mm}$.

Radula ( $\mathrm{n}=16$ of different morphs). Lateral teeth very similar in all species of Amalda, unicuspid, hook-shaped (Fig. 7A). Central tooth normally tricuspid with central cusp shortest. Some variation in central tooth shape (Fig. 7B-G); central cusp from extremely short, nearly obsolete, to subdivided in two cusplets, or with additional denticles on side. Cusps of the central tooth either with smooth edges, or serrated (Fig. 7G). Morphological variation not related to geographical distribution. 

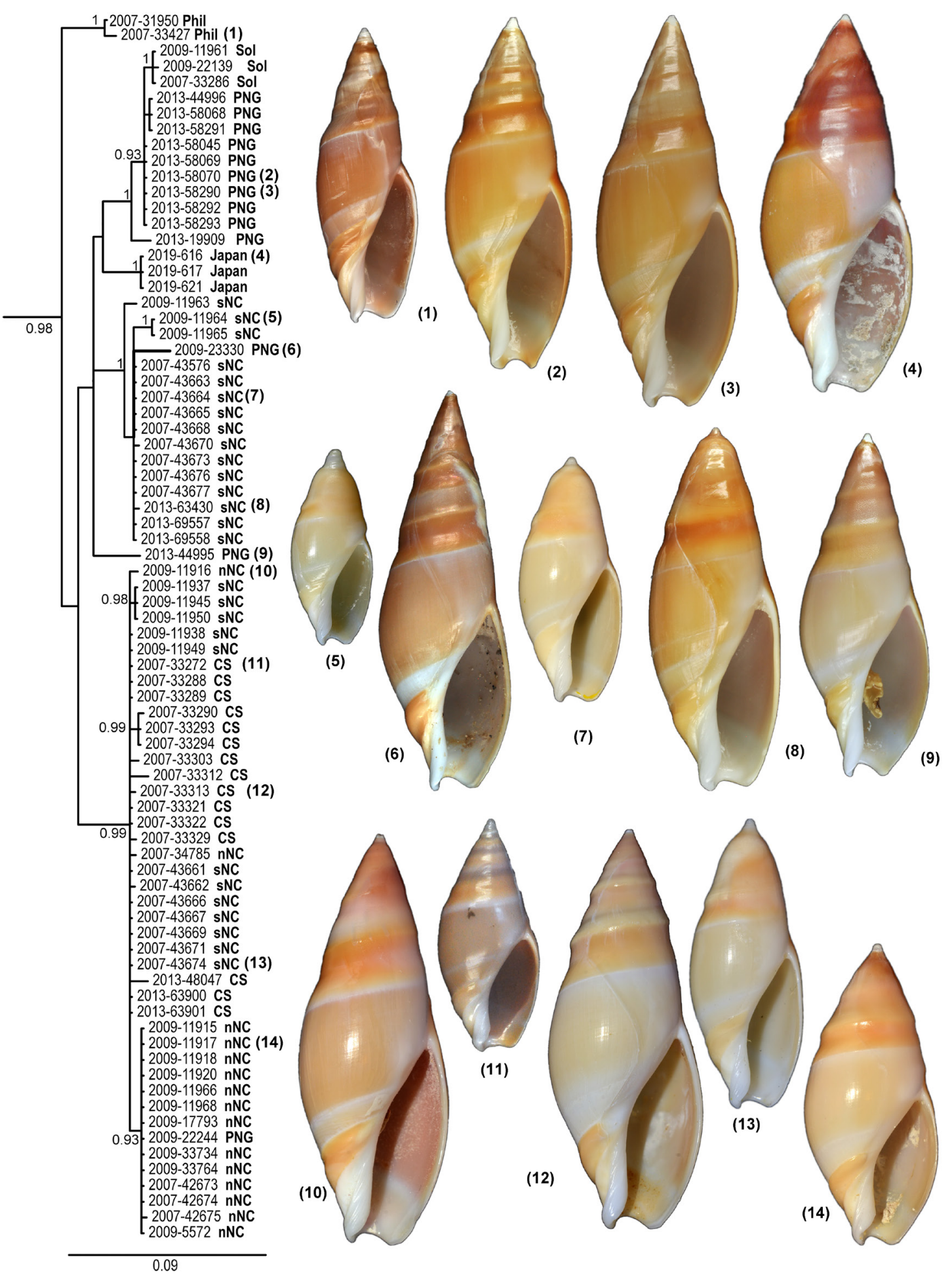

Fig. 2. Molecular phylogeny of Amalda hilgendorfi (von Martens, 1897) produced by a Bayesian analysis of the Coxl gene dataset. Outgroups and other species of Amalda have been removed from the tree. Only posterior probabilities $\geq 90 \%$ are shown. The unit for the scale is "substitutions/site". The geographical distribution and morphological morphs are coded for each specimen: Phil=Philippines; Sol=Solomon Islands; $\mathrm{PNG}=$ Papua New Guinea; $\mathrm{sNC}=$ South New Caledonia; $\mathrm{nNC}=$ North New Caledonia; $\mathrm{CS}=$ Coral Sea. Numbers in parentheses at the tips of the tree link the MNHN IM voucher number to the corresponding photo on the right. 


\section{Remarks}

Molecular analysis demonstrated high heterogeneity of this species with several subclades, mostly geographically determined (Fig. 2), with groupings from Japan, the Philippines, Papua New Guinea and the Solomon Islands, north of New Caledonia and the Coral Sea, and south of New Caledonia and Norfolk Ridge. This structure is, however, not clear-cut; for example, individuals with identical haplotypes are found in northern New Caledonia (MNHN IM-2009-33734) and Papua New Guinea (MNHN IM-2009-22244) (Haplotype \#18, Fig. 3). At the same time, the specimens collected in the south of New Caledonia are grouped in two different subclades, one of which also includes one specimen from Papua New Guinea, while the second one includes specimens from southern and northern New Caledonia and the Coral Sea, as well as one specimen from Papua New Guinea.

This suggests that despite a non-planktotrophic larval development, larval dispersal in A. hilgendorfi over time can take place across large geographic distances. The presence in New Caledonia of two highly divergent genetic groups (marked by green oval and green rectangle on Fig. 3), both with affinities with haplotypes from Papua New Guinea, suggests that larval exchange between these distant regions might have been quite frequent.

The species is variable in shell shape and colouration. Several morphs could be distinguished, mostly geographically determined and not necessarily distinct molecularly. This has resulted in the description of three subspecies. Moreover, morphologically very similar sympatric specimens may belong to different subclades. For a better characterization of the variability, we describe these morphs separately.

\section{General distribution}

Amalda hilgendorfi is broadly distributed in the West Pacific, recorded from Japan, the Philippines, Papua New Guinea and the Solomon Islands, eastern Australia, the Coral Sea, and New Caledonia.

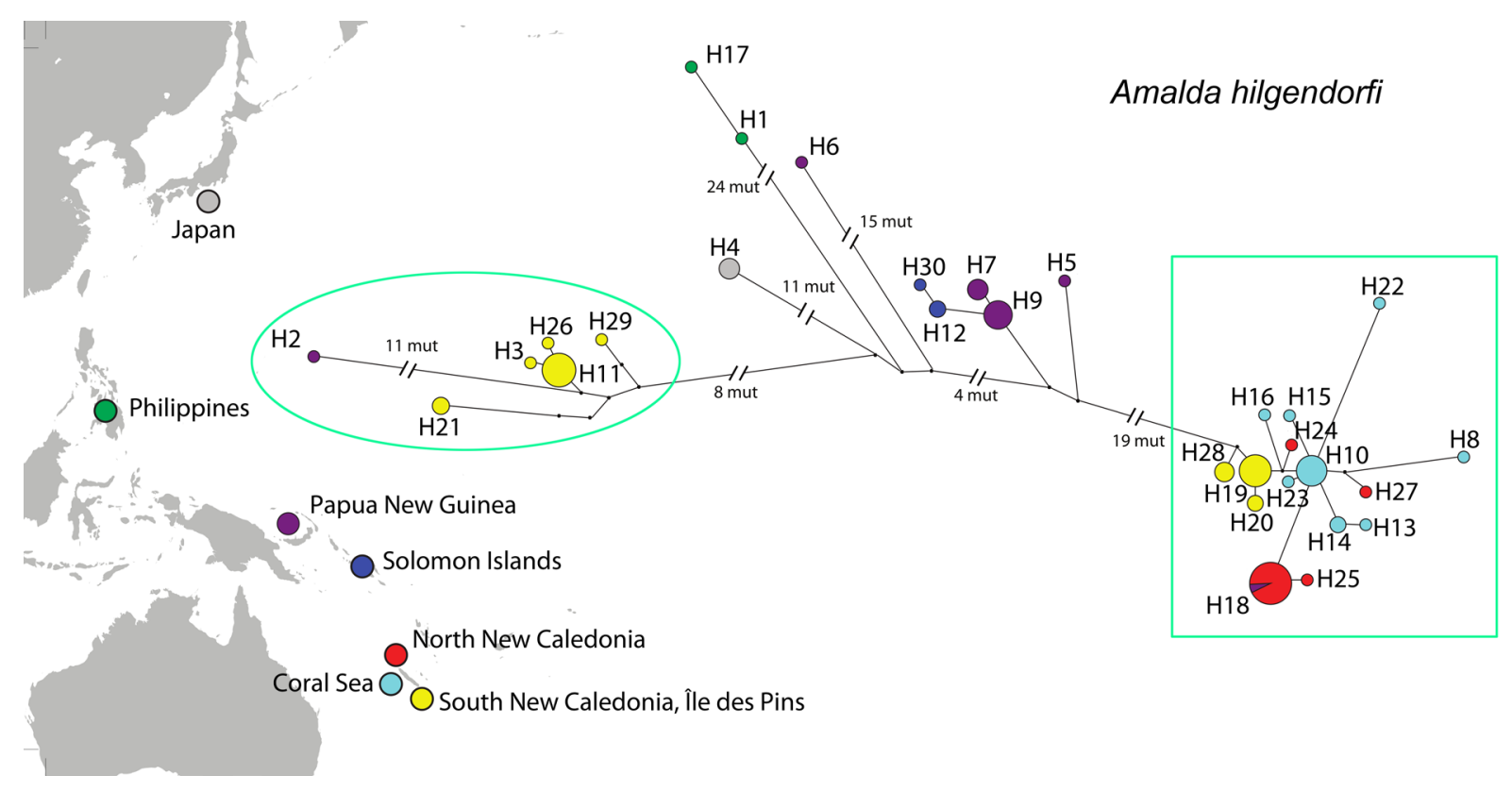

Fig. 3. Median-joining haplotype network based on Coxl sequences of Amalda hilgendorfi (von Martens, 1897). Circles are colour coded by general location reported on the map and sized according to each haplotype's relative abundance. Lengths of the lines connecting haplotype circles are proportional to the number of nucleotide differences among haplotypes. Green rectangle and oval encircle assemblages of haplotypes from New Caledonia (each including a specimen from Papua New Guinea). 


\section{Nominotypical (Japan) morph}

Figs 2 (as Japan), 4A-D

\section{Material examined}

Three sequenced specimens (Table 1).

\section{Remarks}

Morph with a single identified haplotype (Fig. 3).

Shell broad-fusiform (SL up to $53 \mathrm{~mm}$, holotype $50 \mathrm{~mm}$ ) dark-coloured, with chestnut-brown primary callus and well-defined light purplish secondary callus (Fig. 4A-D). Body cloak orange-brown. Olivoid band light yellowish. Upper anterior band strongly convex, of same colour as body whorl cloak, lower anterior band much lighter, yellowish. Plication plate white, with 3-4 indistinct to nearly obsolete plicae. First protoconch whorl diameter 0.8-0.92 mm (mean 0.88, $\mathrm{n}=3$ ). Depth range 150-350 m (Tsuchida 2017), sequenced specimens from $230-280 \mathrm{~m}$.

\section{Philippines morph}

Figs 2 (as Phil), 4E-G

\section{Material examined}

Two sequenced specimens (Table 1).

\section{Remarks}

Both sequenced specimens cluster together (Fig. 2), two haplotypes identified (Fig. 3).

Shell slender (largest specimen with SL $40.3 \mathrm{~mm}$ ), coloured in different shades of brown, with lighter olivoid band and slightly convex upper anterior band having nearly median obtuse ridge (Fig. 4). In shell shape and colouration this form matches the subspecies A. hilgendorfi vezzaroi Cossignani, 2015, described from Aliguay Island, Philippines. This same morph is illustrated by Poppe (2008) as Amalda vernedei herlaari van Pel, 1989 (part: pl. 546 fig. 7) from Balut Island in 100-150 m; this illustrated shell attains $67 \mathrm{~mm}$, which is significantly larger than ours. Depth range of sequenced specimens $437-740 \mathrm{~m}$.

\section{Papua New Guinea and Solomon Islands morph}

Figs 2 (as PNG and Sol), 4H-L

\section{Material examined}

\section{Sequenced material}

16 sequenced specimens (Table 1).

\section{Not sequenced material}

SOLOMON SEA • 1 lv; SE Engeneer group Island; $10^{\circ} 45^{\prime} \mathrm{S}, 1^{\circ} 1^{\circ} 06^{\prime} \mathrm{E}$; 470-526 m deep; MADEEP; stn DW4300; MNHN IM-2013-45679 • 1 lv; SE of d'Entrecasteaux Islands; 9 ${ }^{\circ} 48^{\prime}$ S, $151^{\circ} 33^{\prime}$ E; 278 420 m deep; MADEEP; stn DW4314; MNHN IM-2013-45800.

PAPUA NEW GUINEA • 1 lv; N Cape King William; 6 ${ }^{\circ} 3^{\prime}$ S, 147 $146^{\circ}$ E; 450-480 m deep; PAPUA NIUGINI; stn DW3992; MNHN IM-2013-19808 • 1 lv; 600' S, 147³8' E; $785 \mathrm{~m}$ deep; PAPUA NIUGINI; stn DW3992; MNHN IM-2013-19856. 


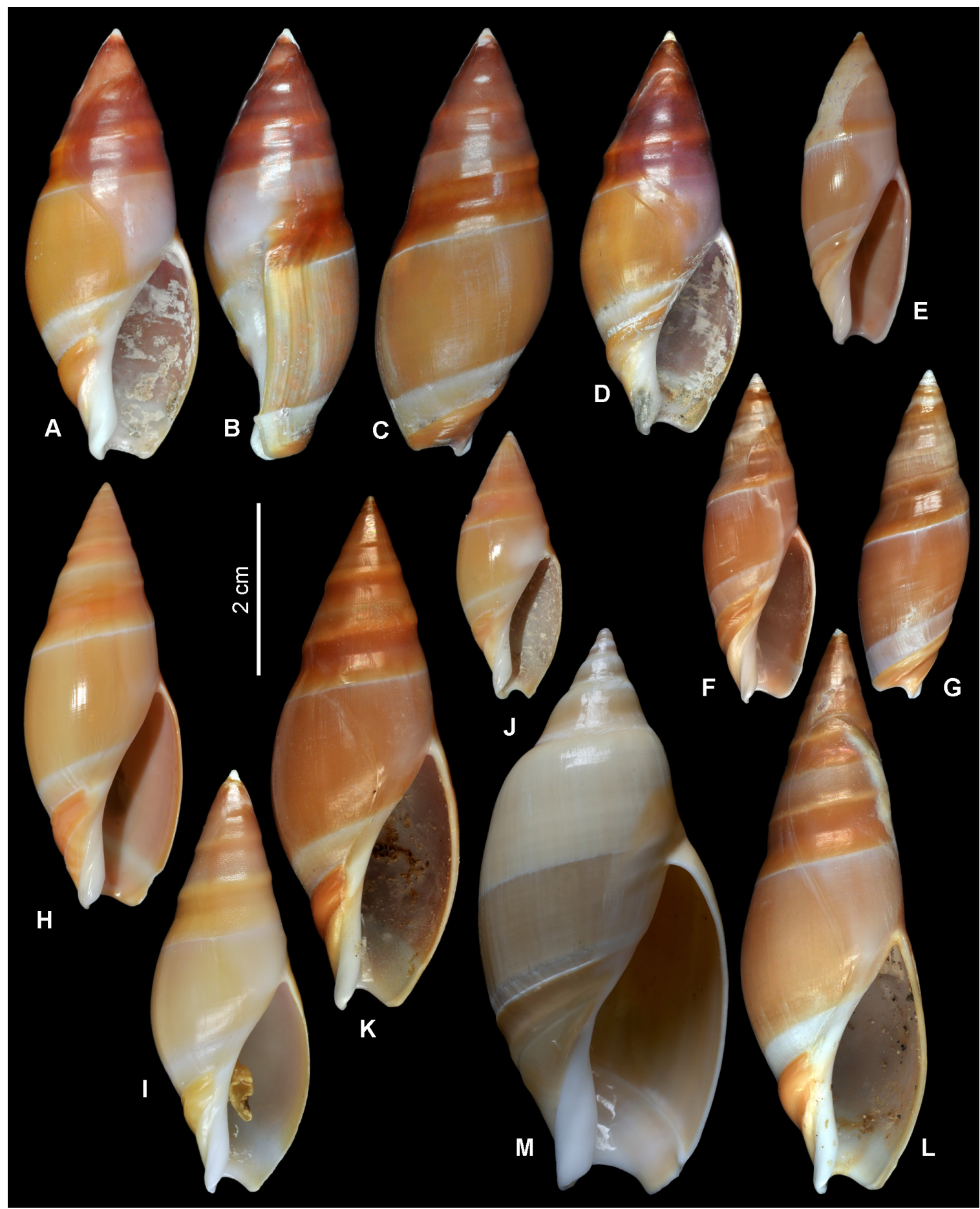

Fig. 4. Amalda hilgendorfi (von Martens, 1897). A-D. Typical morph, Japan. A-C. MNHN IM-2019616, SL $53.1 \mathrm{~mm}$. D. MNHN IM-2019-621, SL 50.0 mm. E-G. Philippine morph. E. MNHN IM-200731950, SL 38.7 mm. F-G. MNHN IM-2007-33427, SL 40.3 mm. H-L. Solomon Islands and Papua New Guinea (PNG) morph. H. Solomons, MNHN IM-2007-33286, SL 52.6 mm. I. PNG, MNHN IM-201344995, SL 51.3 mm. J. Solomons, MNHN IM-2009-11961, SL 32.9 mm. K. PNG, MNHN IM-200922244, SL $63.1 \mathrm{~mm}$. L. PNG, MNHN IM-2009-23330, SL $69.3 \mathrm{~mm}$. M. Amalda tankervillii (Swainson, 1825), Venezuela, Isla de Margarita, 30-35 m, collection of Ron Voskuil, RV 0175, SL $80 \mathrm{~mm}$. Photo by Ron Voskuil et al. (2011) (http://olivirv.myspecies.info/en/taxon-pages/ancillaria-tankervillii). Shells (except $\mathrm{M}$, reduced) at the same scale. 


\section{Remarks}

The population from the Solomon Islands and Papua New Guinea is molecularly heterogeneous; although most of them forming a highly supported clade (Fig. 2), some specimens are scattered along the tree. One specimen (MNHN IM-2009-23330, Fig. 4L) groups with the morph from south of New Caledonia; while another (MNHN IM-2009-22244, Fig. 4K) groups with the specimens from north of New Caledonia sharing the same haplotype (Fig. 3). In total, seven haplotypes were identified (two from the Solomon Islands and five from Papua New Guinea).

Shell large (SL up to $81.2 \mathrm{~mm}$ (MNHN IM-2013-45800), although most specimens are below $55 \mathrm{~mm}$ ), resembling the population from north of New Caledonia, although generally of darker orange-brown colour and lacking the purplish colouration of the callus that is often present in the northern New Caledonia morph. Upper teleoconch whorls sometimes with obtuse calloused carina. Upper anterior band either evenly strongly convex or with poorly defined submedian carina, lower anterior band always yellow-brown, although sometimes very light. Columellar ridges differently pronounced, 3-7 in number.

This form was described as Amalda vernedei herlaari van Pel, 1989 (Arafura Sea, no exact locality), and later considered a subspecies of $A$. hilgendorf (Cossignani 2015). The shell can attain $98 \mathrm{~mm}$ (holotype of Amalda vernedei herlaari). Depth range 335-785 m.

\section{New Caledonia morphs}

Figs 2 (as CS, nNC, sNC), 5, 6, 7F-G

\section{Remarks}

The specimens from New Caledonia form two distinct and supported molecular subclades (Fig. 2). One of them includes only specimens from south of New Caledonia (mostly around Île des Pins), while the second one combines specimens from southern and northern New Caledonia as well as from the Coral Sea. Each subclade includes one specimen from Papua New Guinea (see above). Morphologically, the specimens from south of New Caledonia around Île des Pins are very similar, although they belong to different subclades. Conversely, specimens from the Coral Sea and north of New Caledonia are morphologically very variable, despite belonging to the same subclade.

\section{Coral Sea morph}

Figs 2 (as CS), 5A-F, 7G

\section{Material examined}

\section{Sequenced material}

15 sequenced specimens (Table 1).

\section{Not sequenced material}

CORAL SEA • Material listed by Kilburn \& Bouchet (1988) • 1 lv; $19^{\circ} 34^{\prime}$ S, $158^{\circ} 40^{\prime}$ E; 400-413 m deep; EBISCO; stn DW2607; MNHN IM-2007-33278 • 1 lv; 20 $51^{\prime}$ S, $161^{\circ} 00^{\prime} \mathrm{E}$; 557-565 m deep; EBISCO; stn CP2643; MNHN IM-2007-33292 • 1 lv; 1945’ S, 158 40' E; 386-428 m deep; KANADEEP 1; stn DW4975; MNHN IM-2013-63902.

\section{Remarks}

Shell large (SL up to $66 \mathrm{~mm}$ ), usually light coloured, rarely nearly white except light yellowish primary callus and anterior band. Very distinct callused carina occupying mid-whorl position appearing on fourth or fifth teleoconch whorl (Fig. 5A-B, D). Secondary callus indistinct. Young specimens oval (Fig. 5E-F), large ones fusiform. Upper part of plication plate light yellowish. Upper anterior band strongly convex, in large specimens with obtuse and very broad (about $2 / 3$ of anterior band) ridge. At least one specimen 


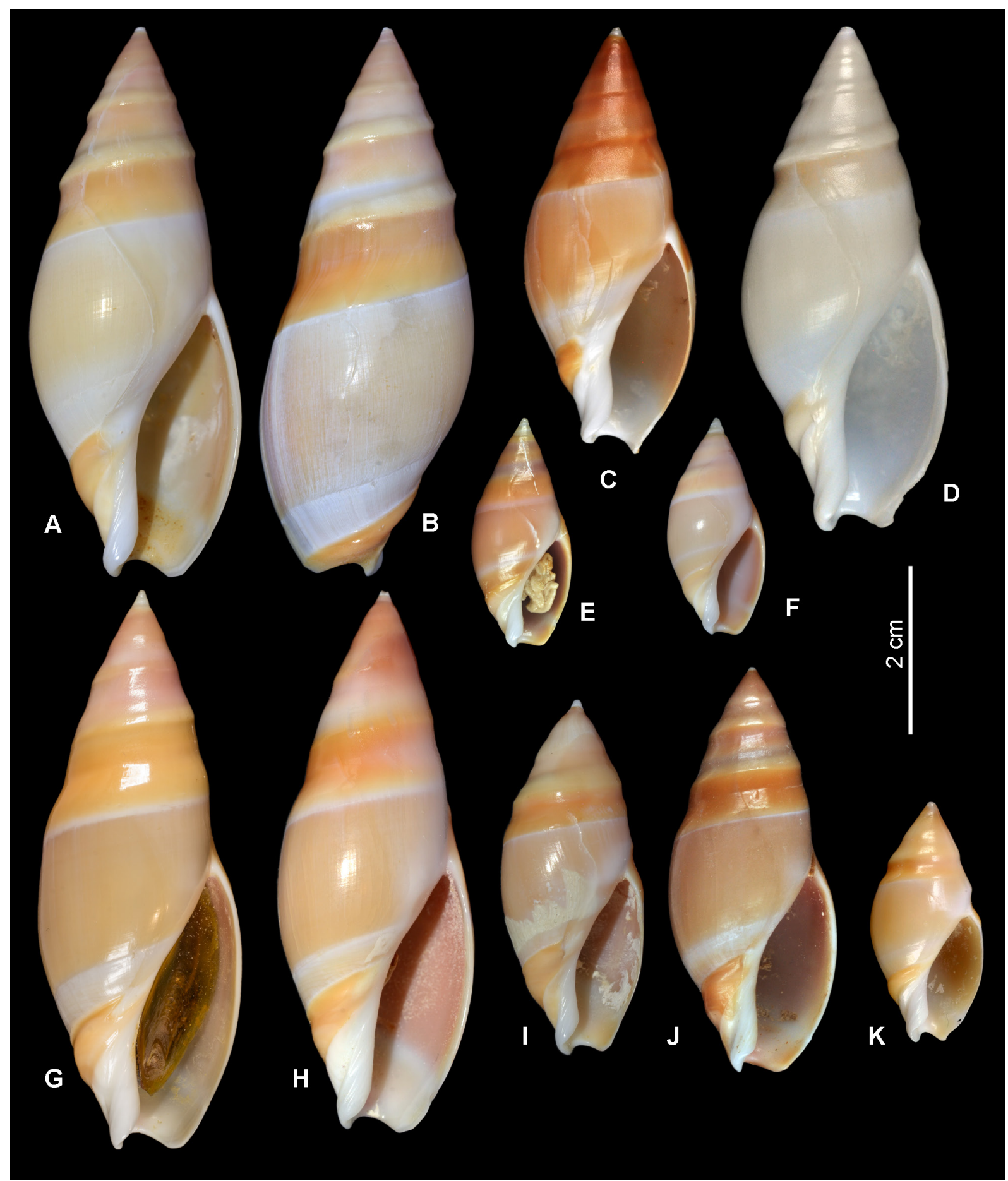

Fig. 5. Amalda hilgendorfi (von Martens, 1897). A-F. Coral Sea morph. A-B. MNHN IM-200733313, SL 66 mm. C. MNHN IM-2007-33289, SL 51.3 mm. D. MNHN IM-2007-33288, SL 60.3 mm. E. MNHN IM-2013-63901, SL 27-3 mm. F. MNHN IM-2007-33312, SL 25.9 mm. G-K. Northern New Caledonia morph $=A$. hilgendorfi richeri Kilburn \& Bouchet, 1988. G. Holotype, MNHN IM-20001378, SL 66.9 mm. H. MNHN IM-2009-11916, SL 65 mm. I. MNHN IM-2009-11918, SL 43.2 mm. J. MNHN IM-2007-42675, SL 48.7 mm. K. MNHN IM-2009-11966, SL 29 mm. Shells at the same scale. 
(SL $51.3 \mathrm{~mm}$, MNHN IM-2007-33289, Fig. 5C) did not have a callused carina on the spire and had a uniformly white plication plate. Number of columellar ridges variable from 2-3 in small specimens to 6-7 in medium-sized and larger ones. First protoconch whorl diameter 0.75-0.92 mm (mean 0.82, $\mathrm{n}=5$ ). The younger specimens of this morph are somewhat similar in colouration to A. aureomarginata and were erroneously identified as such by Kilburn \& Bouchet (1988). Depth range 390-750 m.

\section{Northern New Caledonia morph (“A. hilgendorfi richeri")}

Figs 2 (as nNC), 5G-K

\section{Material examined}

\section{Sequenced material}

15 sequenced specimens (Table 1 ).

Not sequenced material

Material listed by Kilburn \& Bouchet (1988).

\section{Remarks}

Shell large (SL up to $76 \mathrm{~mm}$ ), somewhat similar to the morph from the Coral Sea, although adult shells are more slender and the callused carina is less developed. Upper anterior band with more defined, relatively narrow, median carina. Plication plate uniformly white. Smaller specimens are more ovoid in shape, with relatively more pronounced carina and uniformly convex upper anterior band; the upper part of plication plate can be yellowish. Upper whorls often have a purplish tint. Number of columellar ridges variable, 2 to 6 , regardless of specimen size. First protoconch whorl diameter $0.80-0.84 \mathrm{~mm}$ (mean $0.83, \mathrm{n}=5$ ). Depth range $360-750 \mathrm{~m}$.

\section{Southern New Caledonia morph ("pupiform")}

Figs 2 (as sNC), 6, 7F

\section{Material examined}

\section{Sequenced material}

26 sequenced specimens (all MNHN) (Table 1).

Not sequenced material

SOUTHERN NEW CALEDONIA • Material listed by Kilburn \& Bouchet (1988) • 1 dd; Île des Pins; $22^{\circ} 48^{\prime} \mathrm{S}, 167^{\circ} 15^{\prime} \mathrm{E}$; 440-470 m deep; TERRASSES; stn CP3115・1 dd; SW of Île des Pins; $22^{\circ} 54^{\prime}$ S, $167^{\circ} 17^{\prime}$ E; 496-505 m deep; KANACONO; stn DW4722 • 2 dd; W of Île des Pins; $22^{\circ} 50^{\prime}$ S, $167^{\circ} 16^{\prime}$ S; 480-505 m deep; VAUBAN 1978-1979; stn DR23 • 5 lv, 1 dd, S of Île des Pins;22 ${ }^{\circ} 53^{\prime}$ S, $167^{\circ} 17^{\prime} \mathrm{E}$; 570-610 m deep; BIOCAL; stn DW $46 \cdot 1 \mathrm{dd}$; S of Grande Terre; $22^{\circ} 56^{\prime} \mathrm{S}, 1^{167^{\circ}} 17^{\prime} \mathrm{E}$; $485-520 \mathrm{~m}$ deep; MUSORSTOM 4; stn CP215 • 1 dd; S of Grande Terre; $22^{\circ} 56^{\prime}$ S, $167^{\circ} 17^{\prime}$ E; 485-520 m deep; MUSORSTOM 4; stn DW223 • 2 worn dd; 22 $2^{\circ} 51^{\prime}$ S, $167^{\circ} 13^{\prime}$ E; 445-460 m deep; MUSORSTOM 4; stn DW229 • 2 dd; S of Île des Pins; $22^{\circ} 52^{\prime}$ S, $167^{\circ} 13^{\prime}$ E; 415 m deep; SMIB 1; stn DW02 • 7 dd; S of Île des Pins; $22^{\circ} 55^{\prime}$ S, $167^{\circ} 16^{\prime}$ E; 490-495 m deep; SMIB 2; stn DW10 • 1 dd; Banc Éponge; $24^{\circ} 54^{\prime}$ S, $168^{\circ} 22^{\prime}$ E; 530 m deep; SMIB 3; stn CP04; • 1 worn dd; Kaimon Maru Bank; $24^{\circ} 45^{\prime}$ S, $168^{\circ} 08^{\prime}$ E; 233 m deep; SMIB 3; stn DW08 1 lv; SW of Île des Pins; $22^{\circ} 59^{\prime}$ S, $167^{\circ} 19^{\prime}$ E; 525 m deep; SMIB 3; stn DW21 • 1 lv, 1 dd; SW of Île des Pins; 2303' S, 167¹9' E; 503 m deep; SMIB 3; stn DW22.

\section{Remarks}

A very peculiar morph with medium-sized shell (SL up to $53.7 \mathrm{~mm}$, usually less than $35 \mathrm{~mm}$ ), occurring only in southern New Caledonia, mostly off Île des Pins, with a few specimens collected on Norfolk Ridge. Despite morphological similarity between specimens, these are genetically heterogeneous, belonging to 
different highly divergent assemblagies of haplotypes (marked by yellow in Fig. 3), some being closer to specimens from northern New Caledonia and the Coral Sea, while others constituting a subclade on the tree (Fig. 2). In total eight haplotypes were identified within this morph.

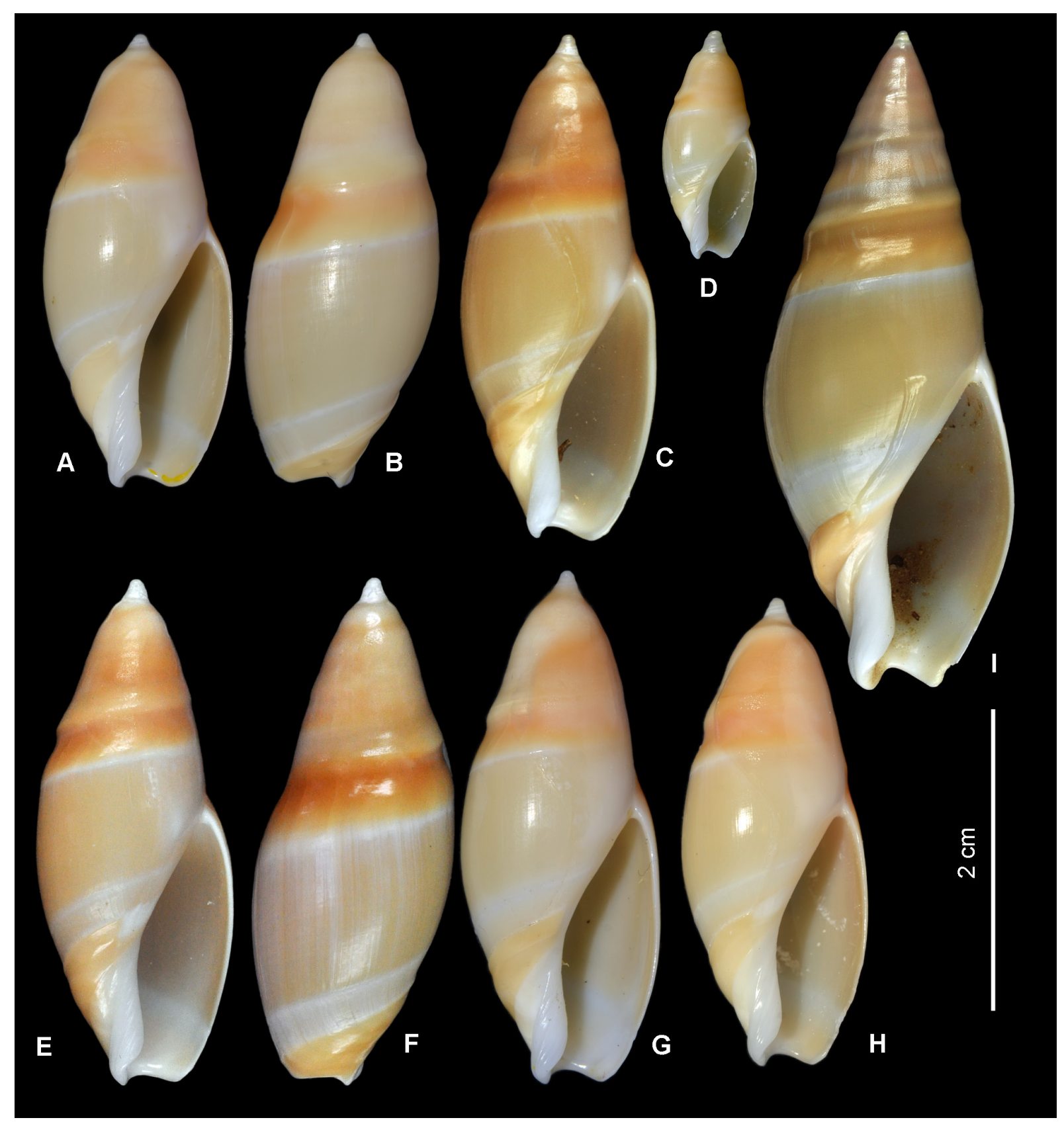

Fig. 6. Amalda hilgendorfi (von Martens, 1897). Southern New Caledonia morph. A-D and E-H belong to two molecularly distinct subclades. A-B. MNHN IM-2007-43664, SL $30.6 \mathrm{~mm}$. C. MNHN IM2007-43673, SL 34.2 mm. D. MNHN IM-2009-11964, SL $15.2 \mathrm{~mm}$. E-F. MNHN IM-2007-43671, SL $33.8 \mathrm{~mm}$. G. MNHN IM-2007-43674, SL $34.7 \mathrm{~mm}$. H. MNHN IM-2009-11945, SL $31.6 \mathrm{~mm}$.

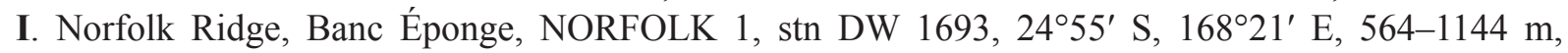
SL $61 \mathrm{~mm}$, specimen not sequenced, shell not to scale. Shells (except I, reduced) at the same scale. 
Shell shape pupiform due to very strong development of primary and secondary calluses on upper teleoconch whorls, while uppermost 2.5-3 whorls (including those of protoconch) remain uncovered, revealing the papillate apex. Except the large development of the callus, the shell shape is rather similar to those in the north New Caledonia morph and some specimens with less developed callus (e.g., MNHN IM-2013-69558 or MNHN IM-2007-43673 on Fig. 6C) are practically indistinguishable (e.g., MNHN IM-2009-11918, Fig. 5I). Columellar ridges rather distinct, 6-7. Upper anterior band usually evenly convex, not subdivided by a ridge. First protoconch whorl diameter $0.84-0.90 \mathrm{~mm}$ (mean $0.86, \mathrm{n}=5$ ). Depth range 233-610 m.

On Norfolk Ridge and off southern New Caledonia, some specimens very similar to those from north of New Caledonia were found in deeper water in $560-650 \mathrm{~m}$ in addition to the pupiform morph. One specimen was collected on Banc Eponge (Fig. 6I) in a haul with a very large depth range, 564-1144 m, but the deepest record needs confirmation. Although none of these specimens were sequenced, there is no doubt of their identity.

Amalda aureomarginata Kilburn \& Bouchet, 1988

Figs $7 \mathrm{H}, 8 \mathrm{~A}-\mathrm{H}, 9 \mathrm{~A}$

Amalda aureomarginata Kilburn \& Bouchet, 1988: 282, 284, figs 9-12 [not figs 13-17=Amalda hilgendorfi].

Amalda aureomarginata - Gratecap 2014 (part): 13, 18, figs 5-8 [not fig. 9=Amalda hilgendorfi].

\section{Type material}

Holotype

SOUTHERN NEW CALEDONIA • 22 ${ }^{\circ} 47^{\prime} \mathrm{S}, 167^{\circ} 15^{\prime} \mathrm{E}$; 430-465 m deep; BIOCAL; stn 45; MNHN IM-2000-1345.

\section{Material examined}

\section{Sequenced material}

20 sequenced specimens (all MNHN) (Table 1).

\section{Not sequenced material}

SOUTHERN NEW CALEDONIA • 1 dd; S of Île des Pins; 225' S, $167^{\circ} 15^{\prime}$ E; 450 m deep; SMIB 1; stn DW09 • 13 dd; SW of Île des Pins; 22 $56^{\prime}$ S, 167¹5' E; 437 m deep; SMIB 3; stn DW25 • 5 dd; SW of Île des Pins; $22^{\circ} 55^{\prime}$ S, $167^{\circ} 16^{\prime}$ E; 450 m deep; SMIB 3; stn DW26 6 dd; SW of Île des Pins; $22^{\circ} 46^{\prime} \mathrm{S}, 167^{\circ} 11^{\prime} \mathrm{E}$; $394 \mathrm{~m}$ deep; stn DW28 • $15 \mathrm{dd}$; SW of Île des Pins; $22^{\circ} 47^{\prime} \mathrm{S}, 167^{\circ} 12^{\prime} \mathrm{E} ; 405 \mathrm{~m}$ deep; SMIB 3; stn DW29 • 2 dd; SW of Île des Pins; $22^{\circ} 55^{\prime}$ S, $167^{\circ} 13^{\prime}$ E; 383 m deep; SMIB 3; stn DW31 • $6 \mathrm{lv}$ and dd; between Île des Pins and Grand Récif Sud; 22 ${ }^{\circ} 56^{\prime}$ S, $167^{\circ} 14^{\prime}$ E; 400-420 m deep; SMIB 4; stn DW65 - 2 dd; between Île des Pins and Grand Récif Sud; $22^{\circ} 56^{\prime}$ S, $167^{\circ} 15^{\prime}$ E; 400-430 m deep; SMIB 4; stn DW66 • 2 dd; between Île des Pins and Grand Récif Sud; $22^{\circ} 55^{\prime}$ S, $167^{\circ} 16^{\prime}$ E; 430-440 m deep; SMIB 4; stn DW68 - 1 dd; between Île des Pins and Grand Récif Sud; $22^{\circ} 55^{\prime}$ S, $167^{\circ} 15^{\prime}$ E; 395 405 m deep; SMIB 4; stn DW69 • 2 dd; Antigonia Bank; 23ํ1' S, $168^{\circ} 04^{\prime}$ E; 305-335 m deep; SMIB 5; stn DW104 - 2 dd; Antigonia Bank; $23^{\circ} 15^{\prime} \mathrm{S}, 168^{\circ} 04^{\prime} \mathrm{E}$; 311-355 m deep; SMIB 8; stn DW185 • 2 dd; $23^{\circ} 17^{\prime}$ S, $168^{\circ} 06^{\prime}$ E; 390-540 m deep; SMIB 8; DW187 • ca 30 dd; S of Île des Pins; $22^{\circ} 48^{\prime}$ S, $167^{\circ} 15^{\prime}$ E; 444-445 m deep; BATHUS 2; stn DW719 • 3 dd; S of Île des Pins; $22^{\circ} 52^{\prime}$ S, $167^{\circ} 16^{\prime}$ E; 530-541 m deep; SMIB 8; stn DW720 • 4 dd; S of Île des Pins; $22^{\circ} 50^{\prime} \mathrm{S}, 1^{\circ} 7^{\circ} 27^{\prime} \mathrm{E}$; 430-433 m deep; SMIB 8; stn DW723 • ca 15 lv and dd; southwest slope of the Dumbéa Pass; 22 ${ }^{\circ} 52^{\prime}$ S, $167^{\circ} 12^{\prime}$ E; $400 \mathrm{~m}$

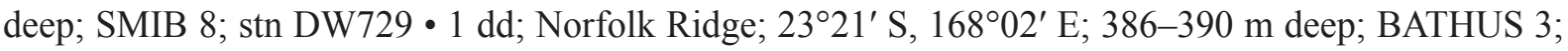


stn DW829 • 2 dd; south of Grande Terre; 22 ${ }^{\circ} 53^{\prime}$ S, $167^{\circ} 12^{\prime}$ E; 390-420 m deep; MUSORSTOM 4; stn DW230 - 4 dd; W of Île des Pins; $22^{\circ} 47^{\prime}$ S, 167¹2' E; 390-400 m deep; Vauban 1978-1979;

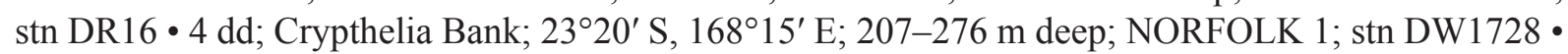
25 dd; SW of Île des Pins; $22^{\circ} 57^{\prime}$ S, $167^{\circ} 16^{\prime}$ E; 427-433 m deep; NORFOLK 1; stn DW1733 • 20 dd; SW of île des Pins; $22^{\circ} 54^{\prime}$ S, $167^{\circ} 13^{\prime}$ E; 403-429 m deep; NORFOLK 1; stn DW1734 • 20 lv and dd; SW of Île des Pins; $22^{\circ} 53^{\prime}$ S, $167^{\circ} 13^{\prime}$ E; 415-445 m deep; NORFOLK 1; stn DW1735• 4 dd; SW of Île des
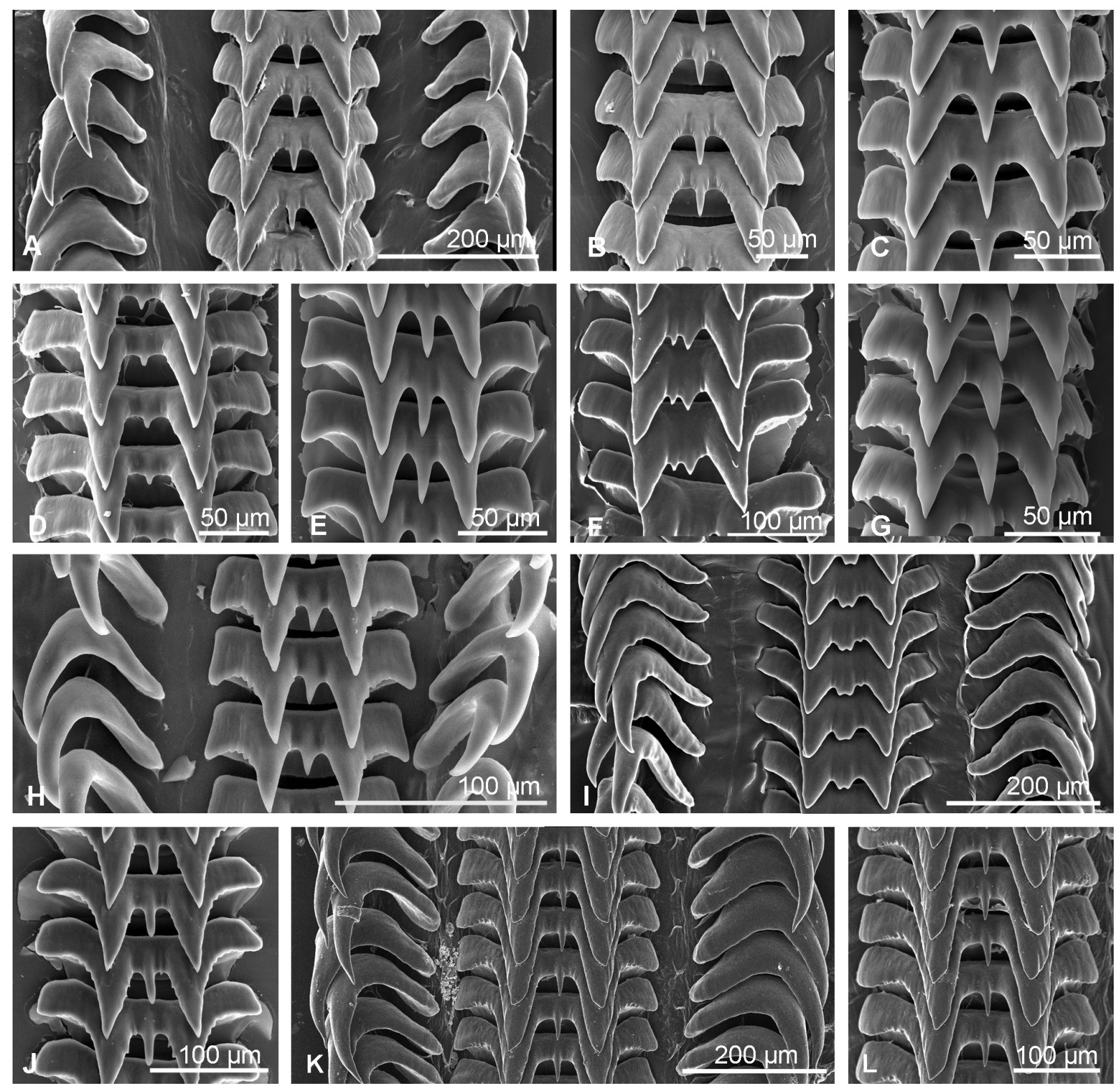

Fig. 7. Radulae of species of Amalda H. Adams \& A. Adams, 1853. A-G. A. hilgendorfi (von Martens, 1897). A-B. MNHN IM-2019-621 (shell on Fig. 4D). C. MNHN IM-2009-11961 (shell on Fig. 4J). D. MNHN IM-2013-58045, Papua New Guinea. E. MNHN IM-2013-19909, Papua New Guinea. F. MNHN IM-2013-63430, southern New Caledonia. G. MNHN IM-2007-33312 (shell on Fig. 5F). H. A. aureomarginata Kilburn \& Bouchet, 1988, MNHN IM-2013-63421, specimen not sequenced, southern New Caledonia. I-J. A. miriky sp. nov. I. Miriky, stn CP3210, specimen not sequenced, Madagascar. J. Miriky, stn DW3215 (shell on Fig. 10J). K-L. A. cacao sp. nov., holotype, MNHN IM2000-35296 (shell on Fig. 11A-E). 


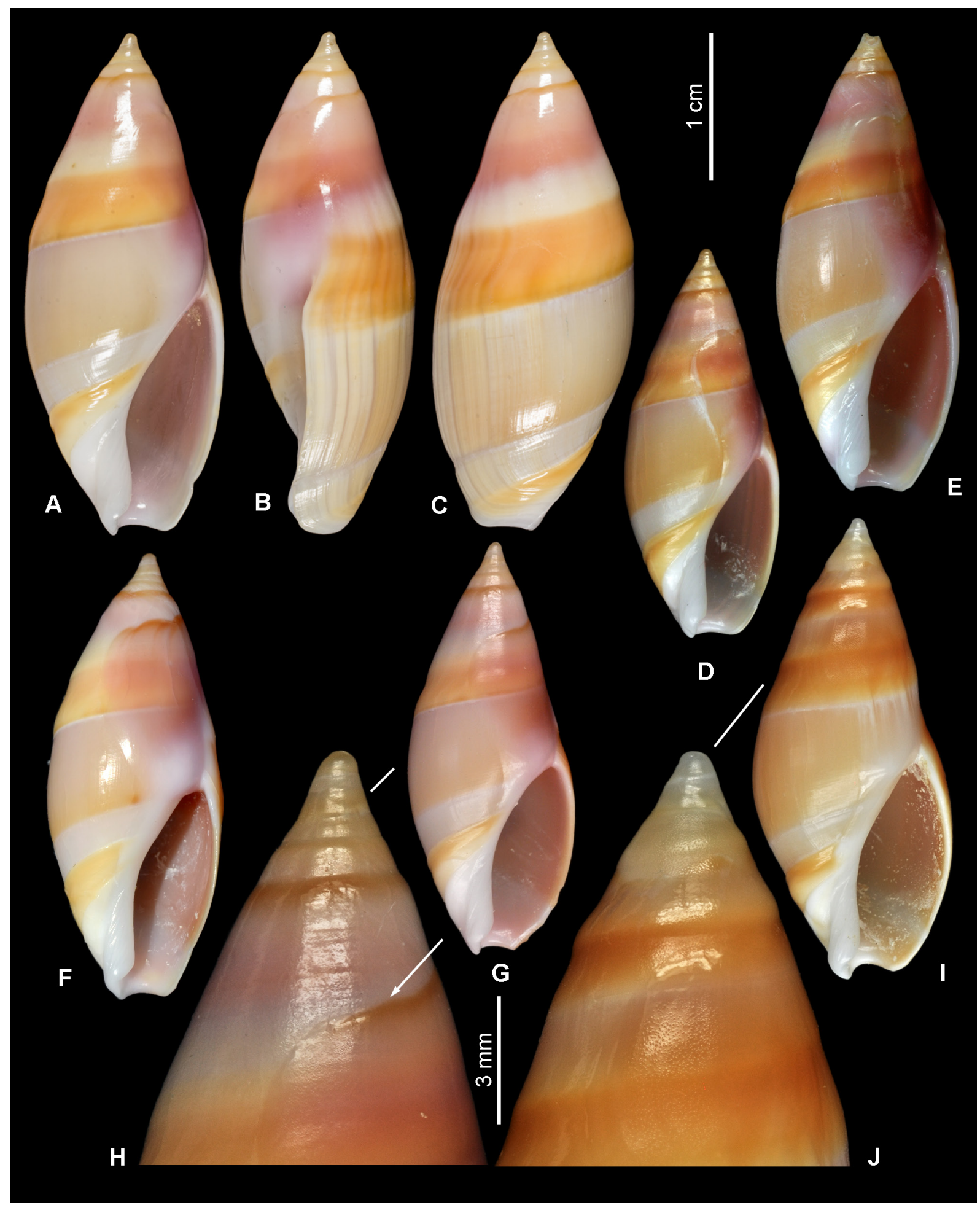

Fig. 8. A-H. Amalda aureomarginata Kilburn \& Bouchet, 1988, southern New Caledonia. A-C. Holotype, MNHN IM-2000-1345, SL $34.1 \mathrm{~mm}$. D. MNHN IM-2007-43644, SL $26.6 \mathrm{~mm}$. E. MNHN IM-200743655, SL $31.5 \mathrm{~mm}$. F. MNHN IM-2007-43551, SL $30.5 \mathrm{~mm}$. G-H. MNHN IM-2007-43654, SL $28.2 \mathrm{~mm}$. I-J. A. hilgendorfi (von Martens, 1897), MNHN IM-2009-11968, northern New Caledonia, SL $31.6 \mathrm{~mm}$. Shells at the same scale; H, J=enlarged upper part of the shell. Arrow on H points at dark brown line, bordering secondary spire callus. 
Pins; $22^{\circ} 51^{\prime} \mathrm{S}, 167^{\circ} 12^{\prime} \mathrm{E}$; 340-381 m deep; NORFOLK 1; stn DW1738 • ca 30 lv and dd; SW of Île des Pins; $22^{\circ} 51^{\prime} \mathrm{S}, 167^{\circ} 14^{\prime} \mathrm{E}$; 404-448 m deep; NORFOLK 1; stn DW1739 • 1 dd, Île des Pins; $22^{\circ} 43^{\prime} \mathrm{S}$, $167^{\circ} 16^{\prime}$ E; 245-300 m deep; NORFOLK 2; stn DW2150 • 30 dd; Île des Pins; $22^{\circ} 52^{\prime}$ S, $167^{\circ} 13^{\prime}$ E; $453-$
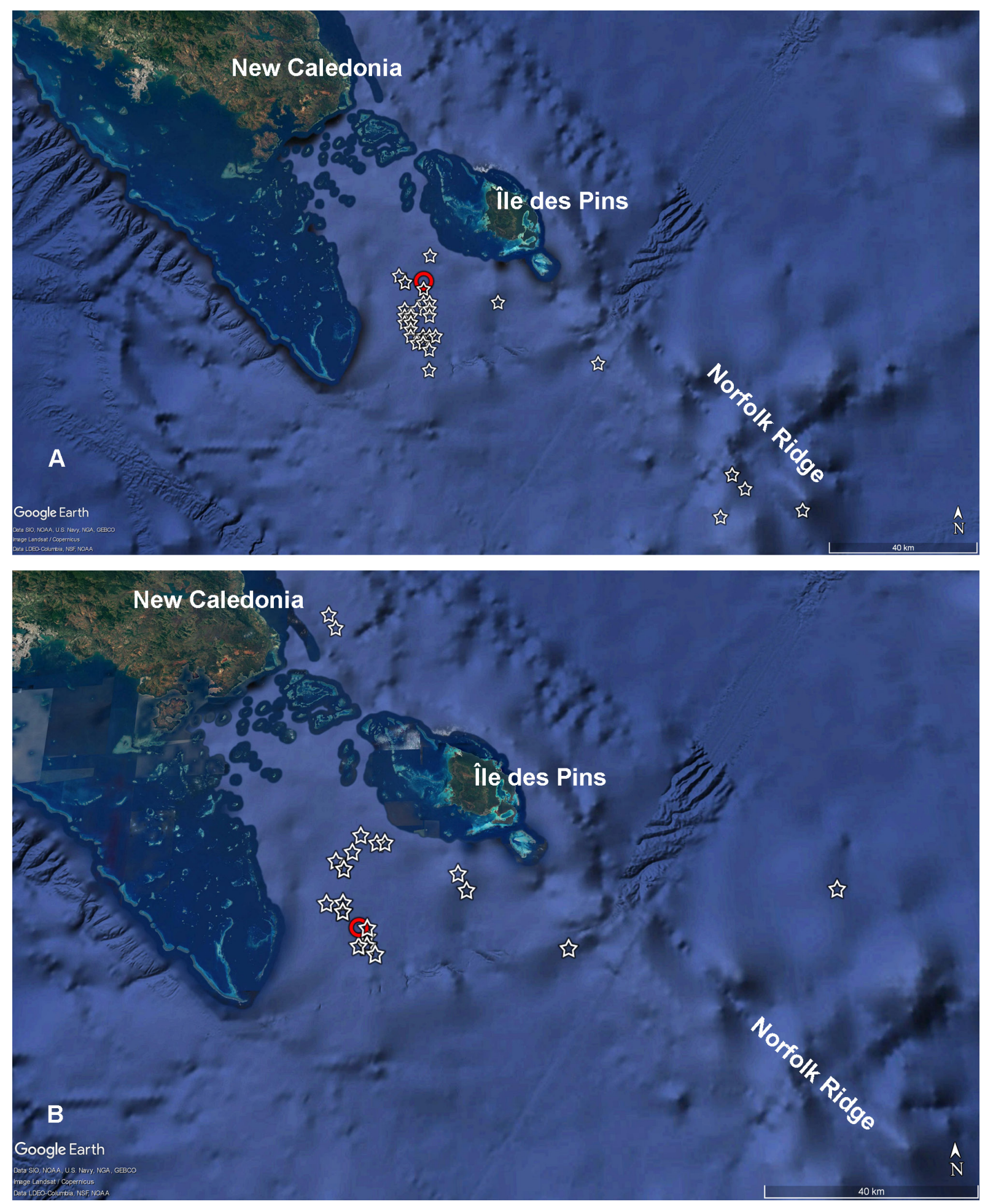

Fig. 9. Distribution map of Amalda aureomarginata Kilburn \& Bouchet, 1988 (A) and A. fuscolingua Kilburn \& Bouchet, 1988 (B) off southern New Caledonia. Red circles = the type localities; stars=indicate stations where the species were recovered. 
455 m deep; NORFOLK 2; stn DW2155 • 1 lv juv; SW of Île des Pins; $22^{\circ} 48^{\prime}$ S, $167^{\circ} 15^{\prime}$ E; 449-465 m

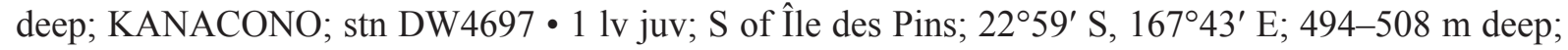
KANACONO; stn DW4746; MNHN-IM-2013-63421.

\section{Description}

Measurements. Small to medium-sized (SL up to $34.5 \mathrm{~mm}$ ).

SHELL. Rather narrow, ovate-fusiform, with narrow base and high, acutely conical spire. First protoconch whorl diameter $0.88-0.94 \mathrm{~mm}$ (mean $0.91, \mathrm{n}=5$ ). Primary spire callus thick, covering all except protoconch and one or two teleoconch whorls, secondary callus forming fairly thin, linguiform pad, extending to second last suture. Plication plate with 4-7 ridges, sometimes bifid. Olivoid groove rather shallow, labral denticle very weak. Upper anterior band weakly convex, nearly flat, may be slightly thickened at rear edge of anterior band. Lower anterior band flat, smooth. Colour light yellowish-brown with paler olivoid band, spire callus with orange-yellow lower band, bordered abapically by narrow light line and creamy upper band with purple tint. Adapically primary callus with narrow but distinct brown borderline. Parietal callus thick, typically purplish-pink. Upper anterior band yellowish orange, lower anterior band and plication plate white.

RADULA (Fig. 7H). With simple rather thin hook-shaped lateral teeth and tricuspid central teeth with central cusp smallest. Outer lower edges of outer cusps serrated.

\section{Remarks}

The radula of a specimen illustrated by Kilburn \& Bouchet (1988: figs 52-56) is rather similar to ours, but the lateral cusps of the central tooth with serrated inner edges as well.

Kilburn \& Bouchet (1988) recognized three local forms: typical (south New Caledonia), Chesterfield (Coral Sea) and northern New Caledonia form, the latter two characterized by a broader oval shell and details of colouration. A molecular analysis, however, revealed that the specimens identified as these two latter forms are in fact subadults of A. hilgendorfi (see Fig. 8I). They differ from A. aureomarginata by the absence of a characteristic reddish-purple or purplish-pink upper part of the parietal callus and the median part of the primary spire callus. Another stable difference is that in A. aureomarginata, the upper limit of the secondary callus is bordered by a narrow distinct brown band (arrow on Fig. 8H), which is not present in A. hilgendorfi. The specimen of Amalda cf. aureomarginata from the Chesterfields illustrated by Gratecap (2014) is A. hilgendorfi.

\section{Distribution}

The confirmed distribution is confined to southern New Caledonia (Fig. 9A), in a limited area off Île des Pins approximately $40 \times 30 \mathrm{~km}$, with a few records from adjacent Norfolk Ridge localities. Depth range 305-541 m.

Amalda miriky sp. nov.

urn:1sid:zoobank.org:act:8EF08658-D739-4E15-A521-6BCD0FCBFCA7

Figs 7I-J, 10

“form or subspecies” of A. hilgendorfi occurring off Madagascar - Kilburn 1996: 25.

Amalda cf. hilgendorfi - Gratecap 2016b: 4, 12, fig. 5. 


\section{Diagnosis}

Shell large, up to $53 \mathrm{~mm}$, fusiform, with large dome-shaped protoconch (diameter of first whorl ca $1.25 \mathrm{~mm}$ ). Primary and secondary calluses very densely and distinctly microshagreened. Olivoid groove very shallow and indistinct. Anterior band separated by distinct fasciolar ridge into upper and twice more narrow lower bands. Upper anterior band has distinct ridge rounded on top. Body whorl cloak from light yellow to light orange, olivoid band pale, upper anterior band orange-brown, lower anterior band and plication plate white. Primary callus orange-brown, spire whorls with slight bluish tint. Protoconch of same colour as primary callus.

\section{Etymology}

The species is named after the expedition, itself named after the fishery boat on which the survey was conducted. Used as a noun in apposition.

\section{Type material}

\section{Holotype}

MADAGASCAR - off NW Madagascar between Nosy-Be and Banc du Leven; $12^{\circ} 38^{\prime} \mathrm{S}, 48^{\circ} 14^{\prime}$ E; 420-436 m deep; MIRIKY; stn CP3183; MNHN IM-2007-36868 (sequenced).

\section{Material examined}

\section{Sequenced material}

13 sequenced specimens (Table 1).

\section{Not sequenced material}

OFF NW MADAGASCAR - 5 lv; between Nosy-Be and Banc du Leven; $12^{\circ} 36^{\prime} \mathrm{S}, 48^{\circ} 16^{\prime} \mathrm{E}$; 331364 m deep; MIRIKY; stn CP3182; MNHN IM-2007-36899, MNHN IM-2007-36879, MNHN IM2007-36852, MNHN IM-2007-36869, MNHN IM-2007-36857 • 38 lv, 10 dd; 12³8' S, 48¹4' E; 420 436 m deep; MIRIKY; stn CP3183; 1 lv specimen with registration MNHN IM-2007-36881 • 2 lv; $1 \mathrm{dd} ; 12^{\circ} 40^{\prime} \mathrm{S}, 48^{\circ} 12^{\prime} \mathrm{E}$; 492-524 m deep; MIRIKY; stn CP3184 • 8 lv; $12^{\circ} 31^{\prime} \mathrm{S}, 48^{\circ} 22^{\prime} \mathrm{E}$; 298-301 m deep; MIRIKY; stn CP3188; 2 lv specimens with registration MNHN IM-2007-38032, MNHN IM2007-36934 • 22 lv; $11 \mathrm{dd} ; 12^{\circ} 30^{\prime} \mathrm{S}, 48^{\circ} 18^{\prime} \mathrm{E}$; 346-376 m deep; MIRIKY; stn CP3189・1 dd; 1243' S,

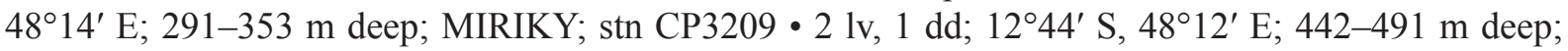
MIRIKY; stn CP3210 • 4 dd; 12³2' S, 4752' E; 244-300 m deep; MIRIKY; stn DW3211 • 6 lv, 6 dd; 12³4' S, 47 54' E; 367-369 m deep; MIRIKY; stn DW3212; 2 lv with registration MNHN IM-

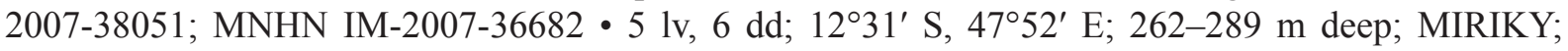
stn DW3213 • 4 lv, 2 dd; 12³3' S, 47052' E; 302-327 m deep; MIRIKY; stn DW3214 • 14 lv, 9 dd; $12^{\circ} 32^{\prime} \mathrm{S}, 47^{\circ} 54^{\prime} \mathrm{E}$; 316-433 m deep; MIRIKY; stn DW3215 • 4 lv, 2 dd; $12^{\circ} 34^{\prime} \mathrm{S}, 47^{\circ} 52^{\prime} \mathrm{E}$; 296-350 m deep; MIRIKY; stn DW3216; 3 lv; MNHN IM-2007-38073; MNHN IM-2007-38074; MNHN IM2007-36669 • 2 lv, 1 dd; $12^{\circ} 33^{\prime} \mathrm{S}, 47^{\circ} 56^{\prime} \mathrm{E}$; 391-438 m deep; MIRIKY; stn DW3217 • $1 \mathrm{lv} ; 12^{\circ} 46^{\prime} \mathrm{S}$,

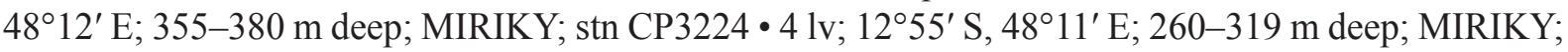
stn DW3228 • 1 dd; West of Cap d'Ambre; $12^{\circ} 08^{\prime}$ S, 48 53' E; 496-501 m deep; MIRIKY; stn DW3195 - 6 dd; $12^{\circ} 07^{\prime} \mathrm{S}, 48^{\circ} 58^{\prime} \mathrm{E} ; 362-431 \mathrm{~m}$ deep; MIRIKY; stn DW3197 • 1 dd; $12^{\circ} 06^{\prime} \mathrm{S}, 48^{\circ} 57^{\prime} \mathrm{E} ; 527-$ 652 m deep; MIRIKY; stn DW3199.

\section{Description (holotype)}

MEAsurements. SL $39.6 \mathrm{~mm}$, AL $19.2 \mathrm{~mm}$, SW $14.9 \mathrm{~mm}$.

SHELL. Shell fusiform with relatively broad base, SW/SL 0.37 ; body whorl evenly convex on right side, very slightly drawn in at olivoid groove, evenly convex on left side, greatest width of body whorl median. Protoconch (Fig. 10D-E) large, broadly domed, first 0.75 whorls with distinct impressed suture, further 


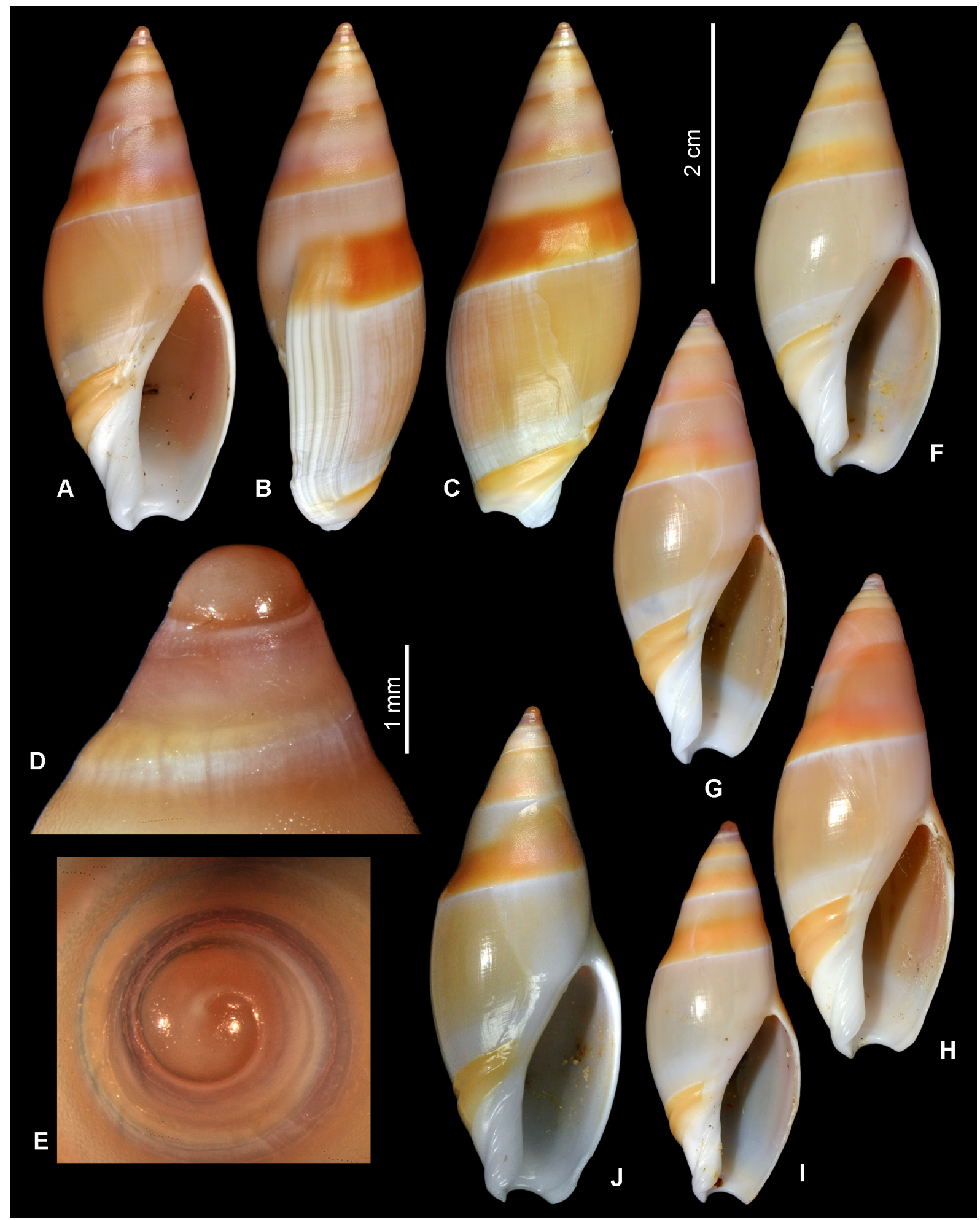

Fig. 10. Amalda miriky sp. nov., Madagascar. A-E. Holotype, MNHN IM-2007-36868, SL 39.6 mm (D-E = enlarged lateral and apical views of the protoconch). F. MNHN IM-2007-38073, SL $35.8 \mathrm{~mm}$ (specimen not sequenced). G. MNHN IM-2007-36842, SL 35.7 mm. H. MNHN IM-2007-36866, SL 37.9 mm. I. MNHN IM-2007-38064, SL 30 mm. J. Miriky, stn DW3215, between Nosy-Be and Banc du Leven, $12^{\circ} 32^{\prime} \mathrm{S}, 47^{\circ} 54^{\prime} \mathrm{E}, 316-433 \mathrm{~m}$, SL $38.9 \mathrm{~mm}$ (specimen not sequenced, radula on Fig. 7J). Scale bars: A-C, F-J=2 cm; D-E $=1 \mathrm{~mm}$. 
suture overlaid by callus. Protoconch borders indistinct, rendering whorl count impossible. Diameter of first whorl $1.23 \mathrm{~mm}$. Spire high, conical; primary callus not thick and covering all whorls except protoconch, slightly impressed at sutures; surface of callus weakly glossy, very densely and distinctly microshagreened; secondary callus very thin, extending to right-ventral side of last whorl and continuing up as fairly thin, tongue-shaped pad, reaching suture of antepenultimate whorl. Surface of secondary callus very similar to that of primary one, borders indistinct. Body whorl cloak glossy, covered by microscopic, dense, waving striae. Olivoid groove very shallow and indistinct, its presence detected by different colours of body whorl cloak and olivoid band rather than by actual depression of surface. Rear edge of anterior band very sharp and distinct. Anterior band strongly microshagreened, mat, and separated into upper (broader) and lower bands by distinct fasciolar ridge. Broader upper anterior band with distinct ridge rounded on top. Lower anterior band nearly flat, nearly twice narrower than upper band. Plication plate with deep and broad groove in upper third, separating adapical largest spiral ridge, followed by another deep groove and four spiral ridges progressively weakening abapically. Columella with indistinct spiral ridges visible as far as rear edge of anterior band. Aperture narrow oval, acute posteriorly, widest medially; outer lip rather thin, in side view very slightly opisthocline, nearly concave, with slight, blunt labral denticle not exactly corresponding to olivoid groove; siphonal notch shallow, symmetrically U-shaped. Body whorl cloak light orange, olivoid band light yellow, upper anterior band orange-brown, lower anterior band and plication plate white. Primary callus orange-brown, similar in tint, but slightly darker than anterior band, abapically to primary callus very narrow whitish spiral band, spire whorls with slight bluish tint. Protoconch of same colour as primary callus. Outer lip inside and lower part of aperture white, aperture inside light pinkish.

RADUla ( $n=2$, not sequenced). Lateral teeth simple, thin, hook-shaped. Central teeth tricuspid, with central cusp much thinner and smaller than lateral ones (Fig. 7J). Lateral cusps with serrated sides. In one specimen central cusp subdivided into two very small cusplets (Fig. 7I), lateral cusps with smooth edge.

\section{Remarks}

The species, which may reach $53.4 \mathrm{~mm}$, is variable in shell slenderness and colouration. The holotype is an average dark specimen, while some specimens are much lighter; some specimens may also have a distinct purplish tint on the secondary callus.

Molecular analysis clearly demonstrates that this is a separate species, although there is a morphological similarity with $A$. hilgendorfi. Both species are reliably distinguished by the protoconch: in A. miriky sp. nov. it is much larger (first protoconch whorl diameter of more than $1.2 \mathrm{~mm}$ vs $0.75-0.92 \mathrm{~mm}$ in $A$. hilgendorfi). Another somewhat similar species from the western Indian Ocean is A. trippneri Kilburn, 1996 from Saya de Malha Bank, depth unknown. The latter differs from A. miriky sp. nov. in its more narrow shell with much taller spire, the presence of the spiral lirae on the spire, as well as indistinct, rather deep, olivoid groove. In general outline and colour, Amalda miriky sp. nov. is also similar to A. hayashii Ninomiya, 1988, differing in exposed protoconch, not covered by callus, by a narrower olivoid band, by completely white plication plate and by more slender shell.

\section{Distribution}

North-western Madagascar, alive in 289-760 m. 


\section{Amalda cacao sp. nov. urn:lsid:zoobank.org:act:CE4694EC-3B8F-40C8-819D-F62DAFEF2AD9}

Figs $7 \mathrm{~K}-\mathrm{L}, 11$

Amalda hilgendorfi richeri, partim - Kilburn \& Bouchet 1988: 288, figs 23-24 (labelled as paratype, but not listed in text under type material).

Amalda cf. hilgendorfi richeri - Gratecap 2014: 14, 19, figs 24-25.

\section{Diagnosis}

Shell large, up to $75 \mathrm{~mm}$, fusiform, with turreted whorls and small broadly dome shaped protoconch (diameter of first whorl ca $0.7 \mathrm{~mm}$ ). Primary and secondary calluses distinctly microshagreened. Border between primary callus and cloak of body whorl very distinct with thin lighter line. Olivoid groove very shallow, obsolete on most part of last whorl. Anterior band separated by distinct fasciolar ridge into upper and slightly narrower lower bands. Upper anterior band with distinct triangular in section ridge. Body whorl cloak chestnut on apertural side and lighter on dorsal side, with axial lines alternating in colour; olivoid band and adjoining narrow zone of cloak of body whorl white, anterior band chestnut brown, plication plate white with weak yellowish spiral band. Primary and secondary calluses dark chocolate brown, parietal pad light, with bluish tint. Protoconch white.

\section{Etymology}

The species name refers to the chocolate colour of the shell. Used as a noun in apposition.

\section{Type material}

\section{Holotype}

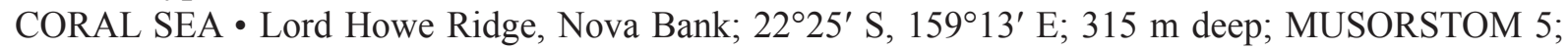
stn CP320; not sequenced; MNHN IM-2000-35296.

\section{Material examined}

\section{Sequenced material}

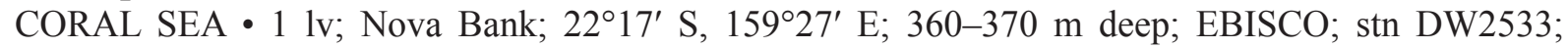
MNHN IM-2007-33287.

\section{Not sequenced material}

CORAL SEA • 1 dd; Kelso Bank; 2406' S, 159²1' E; 295-310 m deep; EBISCO; stn DW2514 • 1 dd; Nova Bank; 22 $2^{\circ} 7^{\prime} \mathrm{S}, 159^{\circ} 25^{\prime} \mathrm{E}$; 487-610 m deep; MUSORSTOM 5; stn DW301 • 1 dd; Nova Bank; $22^{\circ} 10^{\prime} \mathrm{S}, 159^{\circ} 26^{\prime} \mathrm{E}$; 385-420 m deep; MUSORSTOM 5; stn DW304 • 1 dd; Kelso Bank; $24^{\circ} 12^{\prime}$ S,

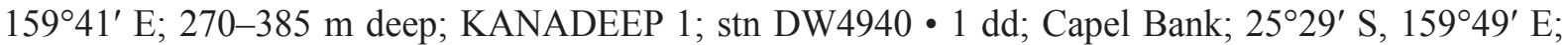

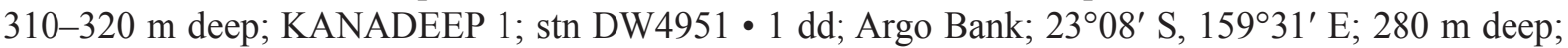
KANADEEP 1; stn DW4958.

SOUTHERN NEW CALEDONIA - Norfolk Ridge • 1 dd; Kaimon Maru Bank; 244ㄴ ${ }^{\prime}$ S, $168^{\circ} 09^{\prime}$ E; 227-232 m deep; NORFOLK 1; stn CP1676 • 1 dd worn; 244' S, 168 $08^{\prime}$ E; 233 m deep; SMIB 3; stn DW08.

\section{Description (holotype)}

MEASUREMENTS. SL $74.9 \mathrm{~mm}$, AL $40.0 \mathrm{~mm}$, SW $29.3 \mathrm{~mm}$.

SHELL. Shell fusiform with relatively narrow base, SW/SL 0.39; body whorl evenly convex on right side, evenly convex on periphery and shell base on left side, slightly concave subsuturally, greatest 
width of body whorl median. Protoconch (Fig. 11D-E) small, broadly domed, first 1.5 whorls with distinct impressed suture, suture further overlaid by callus. Limit of protoconch indistinct, rendering whorl count impossible. Diameter of first whorl $0.68 \mathrm{~mm}$. Spire high, turreted; primary callus not thick and covering all whorls except protoconch and uppermost teleoconch whorls, distinctly impressed on suture; surface of callus glossy, distinctly microshagreened, more dense in suture areas. Secondary callus very thin, forming distinct thickened pad on parietal wall, extending to right ventral side of last whorl and continuing up to form a fairly thin, tongue-shaped pad, reaching suture of antepenultimate

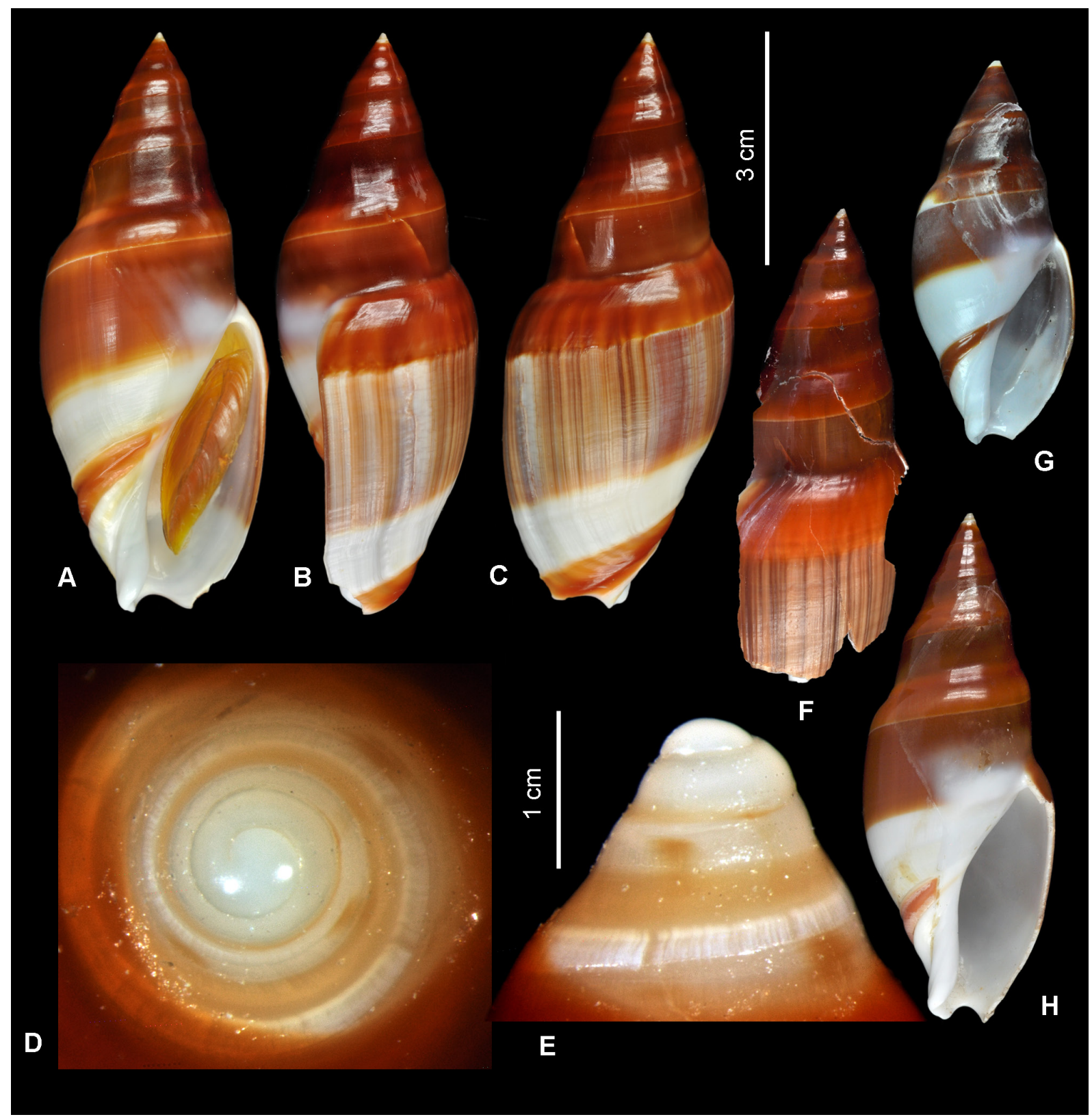

Fig. 11. Amalda cacao sp. nov. A-E. Holotype, MNHN IM-2000-35296, SL 74.9 mm (D-E =enlarged apical and lateral views of the protoconch), specimen not sequenced. F. MNHN IM-2007-33287,

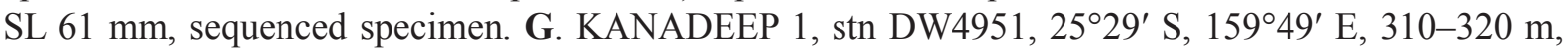
Capel Bank, SL $50 \mathrm{~mm}$, specimen not sequenced. H. NORFOLK 1, stn CP1676, 244ㄴ $4^{\prime} \mathrm{S}, 168^{\circ} 09^{\prime} \mathrm{E}$, 227-232 m, Norfolk Ridge, SL $67.1 \mathrm{~mm}$, specimen not sequenced. Shells at the same scale. 
whorl. Surface of secondary callus very similar to that of primary one, its borders indistinct. Body whorl cloak glossy, covered by indistinct spiral riblets of variable width. Olivoid groove very shallow, obsolete on most part of last whorl and present on last $1 / 3$ whorl. Rear edge of anterior band very sharp and distinct near columella, becoming blurred and sinuous on dorsal side of last whorl towards aperture lip. Anterior band subdivided in upper and lower anterior bands by distinct, step-like, fasciolar ridge. Upper anterior band slightly broader, with distinct, nearly median, additional ridge, triangular in section. Lower anterior band nearly flat. Plication plate with shallow, rather broad, median groove. No ridges on plication plate and columella. Aperture narrow oval, acute posteriorly, widest in its lower third; outer lip thin, very slightly opisthocline in sideview, weakly concave, without visible labral denticle; siphonal notch shallow, symmetrically U-shaped. Body whorl cloak chestnut on apertural side and lighter on dorsal side, with axial lines alternating in colour, corresponding to growth lines; olivoid band and adjoining narrow zone of body whorl cloak white, anterior band chestnut brown, plication plate white with weak yellowish spiral band. Primary and secondary calluses dark chocolate brown, parietal pad light, with bluish tint. Protoconch white. Outer lip with broad spiral brownish band, corresponding to cloak, white deeper inside.

OPERCULUM. Large, spanning most of aperture, lanceolate, with subterminal nucleus near lower operculum edge.

RADULA (holotype) (Fig. 7K-L). Lateral teeth thick, hook-shaped. Central teeth strongly overlapping, tricuspid, with broad lateral flaps. Lateral cusps and lateral flaps with several distinct grooves on outer side, flattened and broad. Central cusp narrow, sharp, much shorter than lateral ones.

\section{Remarks}

This very distinct species differs from most other known species of Amalda in the combination of its dark brown colour and a rather broad shell with high turreted spire. In colour pattern, it resembles specimens of Amalda raoulensis Powell, 1967 illustrated by Hart (1995) from about $100 \mathrm{~m}$ depth on Colville Ridge off the North Island of New Zealand, but the latter differs in having a smaller (up to 56 $\mathrm{mm}$ ) shell with a relatively lower spire. It should be mentioned that the holotype of Amalda raoulensis is a beach worn faded specimen with a very strong, callused, peripheral spiral keel which dominates the shell appearance (Powell 1967), and the conspecificity of the specimens illustrated by Hart (1995) with the types of Amalda raoulensis needs confirmation.

The shell of the only sequenced specimen of $A$. cacao sp. nov. is broken into pieces, but the intact upper teleoconch whorls (Fig. 11F) are identical to the holotype, leaving no doubt on their conspecificity. Kilburn \& Bouchet (1988) considered it to be a colour variant of Amalda hilgendorfi richeri, but CoxI data clearly indicate that it is a separate species.

\section{Distribution}

Live collected in the Coral Sea; dead specimens also known from Kaimon Maru Bank on Norfolk Ridge. Depth range: alive at 315-360 m, empty shells at $227-487 \mathrm{~m}$.

Amalda montrouzieri (Souverbie, 1860)

Figs $12,13 \mathrm{~A}-\mathrm{C}, 14 \mathrm{~A}-\mathrm{B}, 17 \mathrm{C}-\mathrm{D}$

Ancillaria montrouzieri Souverbie, 1860a: 207.

Ancillaria montrouzieri - Souverbie 1860b: 324, pl. 11 fig. 3. — Reeve 1864: pl. 4 fig. 9.

Amalda montrouzieri - Kilburn \& Bouchet 1988: 278-281, figs 1-8, 38-39, 51, 53. — Gratecap 2014: 13 , 18, figs $1-4$. 


\section{Type material}

\section{Syntypes}

NEW CALEDONIA • 1 shell; "Insul. Lifu? (Loyalty). Insul. Art?" [Souverbie 1860a]; Île des Pins [Souverbie 1860b]; MNHN IM-2000-1367 3 shells; same collection data as for preceding; MNHN IM2000-1475 (Fig. 12A-C).

\section{Material examined}

\section{Sequenced material}

SOUTHERN NEW CALEDONIA・ 1 lv; Baie du Prony; 12-18 m deep; MNHN IM-2013-80199.

\section{Not sequenced material}

Material mentioned in Kilburn \& Bouchet (1988), about 50 lots, 110 specimens.

\section{Description}

MEAsurements. Shell medium in size (SL up to $41.5 \mathrm{~mm}$, usually less than $30 \mathrm{~mm}$ ).

SHELL. Ovate-fusiform, with a cyrtoconoid spire. Primary spire callus thick, weakly microshagreened, covering all whorls, including most of protoconch rendering measurements inaccurate, and with weak spiral lirae (8-10 on penultimate whorl). Secondary callus medium thick, forming extensive pad on right side of spire. Plication plate with 2-4 (usually 3) ridges. Olivoid groove from shallow to rather deep, labral denticle weak, obtuse. Upper anterior band very weakly convex, nearly flat. Lower anterior band flat, smooth. Colour from uniformly white, to chestnut brown. In darker coloured specimens, primary spire callus and upper anterior band darker, olivoid band lighter than body whorl cloak, plication plate white.

Radula ( $\mathrm{n}=2$, not sequenced) (Fig. 13A-C). Very similar in these two. Central tooth tricuspid, with central cusp $1 / 3$ smaller than lateral ones. All cusps, as well as lateral flaps of central tooth, with irregular distinct serration.

Live SPECimens (Fig. 14A-B). With truncated and notched posteriorly foot. Parapodia opaque, greyish, with scarce slightly darker speckles, can completely envelop shell. Propodium, anterior part of parapodia and siphon with more dense speckles.

\section{Remarks}

The species is quite variable in shell shape and particularly in colouration, with many specimens pure white or with lightly coloured secondary callus (e.g., Fig. 12F, I). The syntypes are the largest examined specimens. Kilburn \& Bouchet (1988: 281) mentioned the existence of "a puzzling morph which is uniformly different in shape (although there are indications of intergradation in this regard) and in its faint ancillid (=olivoid) groove" at larger depths $(175-420 \mathrm{~m})$ (Fig. 12J-K). This morph differs from A. montrouzieri and A.alabaster sp. nov. in its narrower shell with taller spire. It may represent a peculiar morph of $A$. alabaster sp. nov. or a separate species.

\section{Distribution}

Southern New Caledonia. Amalda montrouzieri is normally distributed at depths of 10-70 m, with specimens occasionally collected down to $130 \mathrm{~m}$; a few empty shells were collected at even larger depths, down to 280 m (SMIB 3, stn DW20). Kilburn \& Bouchet (1988) cited some extralimital records, mostly on the basis of published records, namely the Loyalty Islands, Fiji, the Ryukyu Islands, and the Philippines. These records should be confirmed with molecular data. 


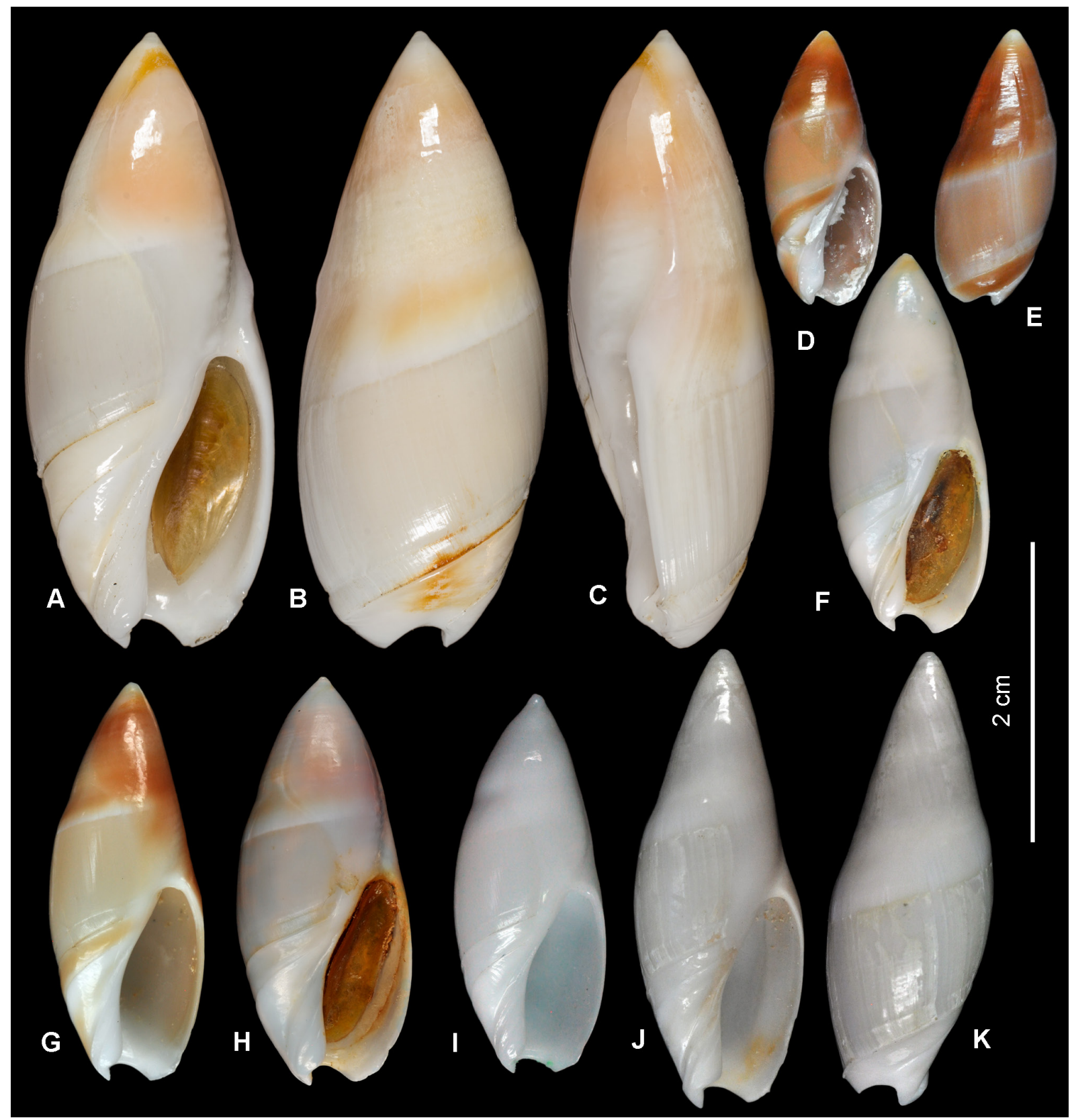

Fig. 12. Amalda montrouzieri (Souverbie, 1860), southern New Caledonia. A-C. Syntype MNHN IM2000-1475, SL 41.4 mm. D-E. MNHN IM-2013-80199, SL $18.7 \mathrm{~mm}$ (sequenced specimen). F. Secteur Île Ouen-Baie du Prony, LAGON, stn DW98, 22 $2^{\circ} 35.7^{\prime} \mathrm{S}, 166^{\circ} 31.8^{\prime} \mathrm{E}, 15 \mathrm{~m}$, SL $25.6 \mathrm{~mm}$. G. Grand Récif Sud, LAGON, stn DW334, $22^{\circ} 38^{\prime} \mathrm{S}, 166^{\circ} 53.6^{\prime} \mathrm{E}, 47-48 \mathrm{~m}$, SL $26.6 \mathrm{~mm}$ (illustrated by Kilburn \& Bouchet 1988: fig. 14). H. Secteur de Nouméa. LAGON, stn DW51, 22 $14.7^{\prime} \mathrm{S}, 166^{\circ} 11.1^{\prime} \mathrm{E}, 10 \mathrm{~m}$,

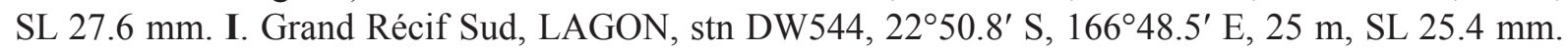
J-K. A. cf. montrouzieri. Deep-water morph, SMIB2, stn DW23, 22 ${ }^{\circ} 31^{\prime} \mathrm{S}, 167^{\circ} 37^{\prime} \mathrm{E}, 410-420 \mathrm{~m}$, SL $30.2 \mathrm{~mm}$ (specimen illustrated by Kilburn \& Bouchet 1988: figs 5-6). All specimens except D-E not sequenced. Shells at the same scale. 
Amalda alabaster sp. nov.

urn:1sid:zoobank.org:act:48866CE5-477F-4ED8-9FDF-D323C1126E56

Figs 13D-E, 15

\section{Diagnosis}

Shell small, up to $27 \mathrm{~mm}$, ovate fusiform, with low broad conical spire and small low dome shaped protoconch (diameter of first whorl ca $0.8 \mathrm{~mm}$ ). Primary callus smooth, shallowly impressed on left side at last whorl suture, secondary callus weakly microshagreened. Olivoid groove very shallow and indistinct. Anterior band separated by distinct fasciolar ridge into upper and slightly broader lower bands. Colour uniformly white.

\section{Etymology}

The specific epithet refers to the white and semitransparent shell. Used as a noun in apposition.
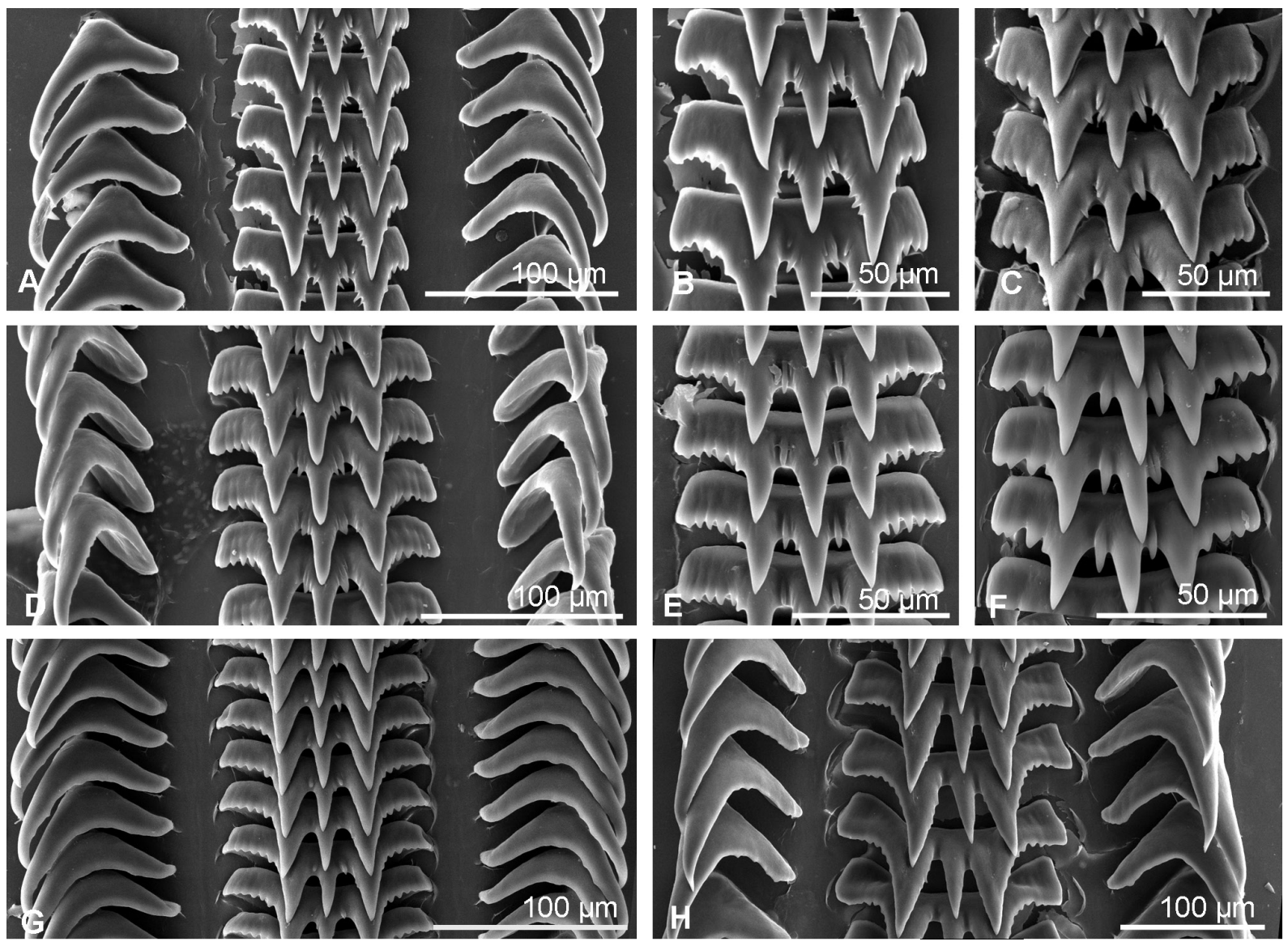

Fig. 13. Radulae of species of Amalda H. Adams \& A. Adams, 1853. A-C. A. montrouzieri (Souverbie, 1860). A-B. Île Ouen - Baie du Prony, LAGON, stn DW239, 22 ${ }^{\circ} 24.3^{\prime}$ S, $166^{\circ} 57.8^{\prime}$ E, 42-43 m, SL $20.2 \mathrm{~mm}$. C. Grand Récif Sud, LAGON, stn DW544, 22 $2^{\circ} 50.8^{\prime} \mathrm{S}, 166^{\circ} 48.5^{\prime} \mathrm{E}, 25 \mathrm{~m}$, SL $25.4 \mathrm{~mm}$ (shell on Fig. 12I). D-E. A. alabaster sp. nov. D. Holotype, MNHN IM-2007-43627, SL 26.7 mm (shell on Fig. 15A-B). E. MNHN IM-2007-43636, SL 17.6 mm. F. A. cf. alabaster, MNHN IM-2013-63897, SL 18.1 mm (shell on Fig. 15H-I). G. A. allaryi Bozzetti, 2007, MNHN IM-201368272 (shell on Fig. 17A). H. A. coriolis Kilburn \& Bouchet, 1988, MNHN IM-2013-63899 (shell on Fig. 18H-I). 


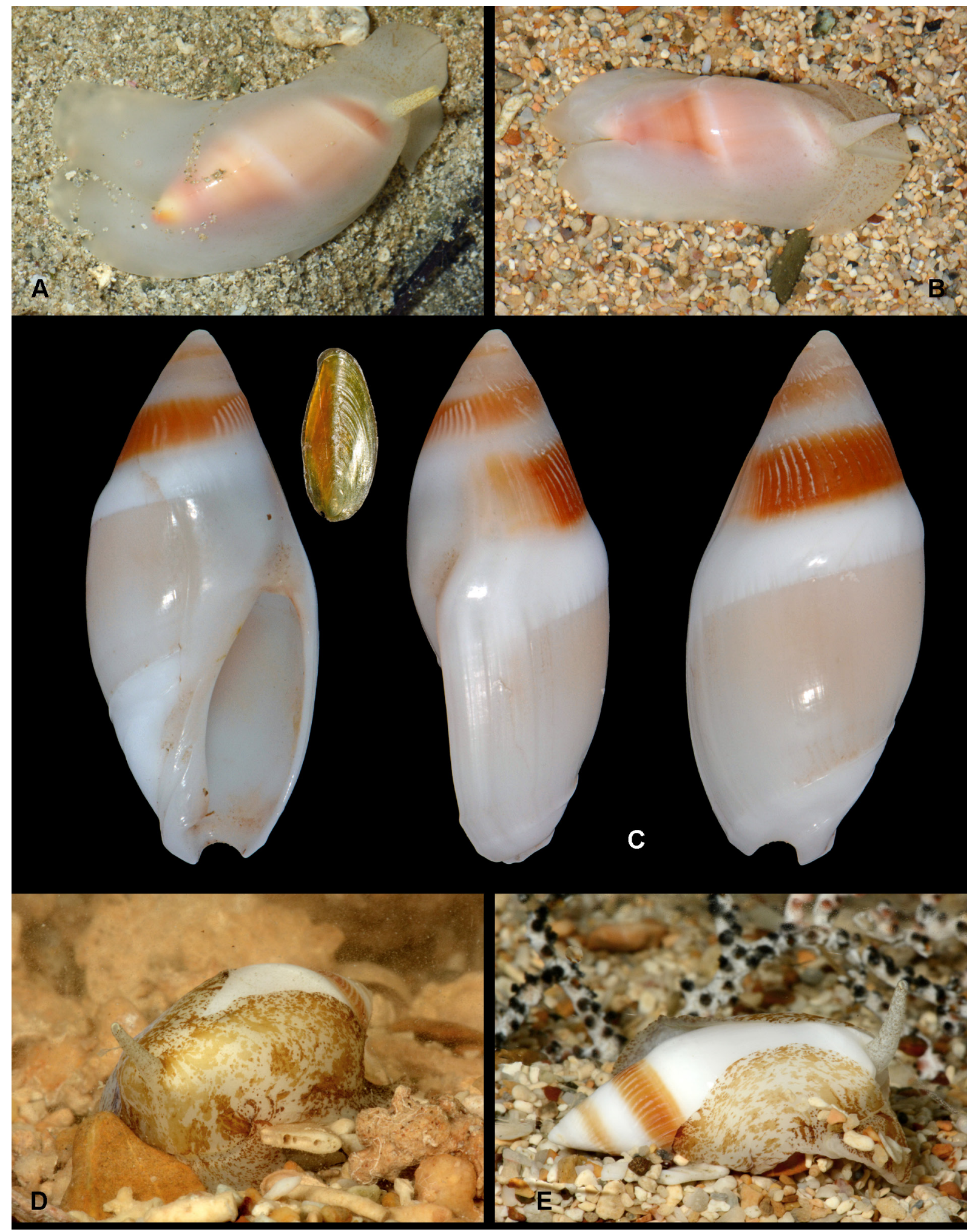

Fig. 14. A-B. Live specimens of Amalda montrouzieri (Souverbie, 1860), Nouméa, 8 m. C-E. Shell and live specimen of $A$. herberti Cossignani, 2013, Nouméa, South Lagoon, about $250 \mathrm{~m}$. Photos courtesy of David Massemin. 


\section{Type material}

Holotype

SOUTHERN NEW CALEDONIA • 22 $2^{\circ} 06^{\prime} \mathrm{S}, 167^{\circ} 03^{\prime} \mathrm{E}$; 190-200 m deep; TERRASSES; stn DW3093; MNHN IM-2007-43627; sequenced.

\section{Material examined}

\section{Sequenced material}

9 sequenced specimens (Table 1).

\section{Not sequenced material}

NEW CALEDONIA - $1 \mathrm{lv}$; type locality; IM-2007-43633 - $3 \mathrm{lv}$; Bassin des Loyauté; $21^{\circ} 45^{\prime} \mathrm{S}$,

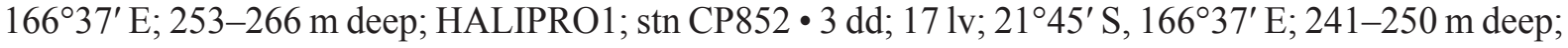
HALIPRO1; stn CP853 - 6 dd; east coast of mainland New Caledonia; $21^{\circ} 48^{\prime} \mathrm{S}, 166^{\circ} 41^{\prime} \mathrm{E}$; $239-250 \mathrm{~m}$ deep; BATHUS 1; stn DW649 • 8 dd; $21^{\circ} 48^{\prime}$ S, $166^{\circ} 41^{\prime}$ E; 264-269 m deep; BATHUS 1; stn DW650 • 5 dd; $21^{\circ} 17^{\prime}$ S, $165^{\circ} 57^{\prime}$ E; 237-298 m deep; BATHUS 1; stn DW654 • 42 lv; 4 dd; $21^{\circ} 45^{\prime}$ S, $166^{\circ} 37^{\prime}$ E; 250 m deep; BATHUS 1; stn CP713.

\section{Description (holotype)}

MeAsurements. SL $26.7 \mathrm{~mm}$, AL $13.5 \mathrm{~mm}$, SW $10.7 \mathrm{~mm}$.

SHELL. Small, ovate fusiform with relatively broad base, SW/SL 0.40; body whorl evenly weakly convex on right side, and slightly bulging on left side due to strong callus, greatest width of body whorl median. Protoconch nearly completely covered by callus with part of first whorl exposed, low dome shaped. First protoconch whorl diameter $0.79 \mathrm{~mm}$. Spire low, broadly conical; primary callus thick and covering all whorls except part of protoconch, shallowly impressed on left side at last whorl suture. Surface of callus glossy, smooth, with weak indistinct spiral ridges, secondary callus thick, with distinct anterior border, joining parietal callus without visible border, extending to right ventral side of last whorl and continuing up to form a thick, tongue-shaped pad that reaches suture of antepenultimate whorl. Surface of secondary callus weakly shagreened. Body whorl cloak weakly glossy, smooth, not microshagreened. Olivoid groove very shallow and indistinct, terminating in short, broadly triangular, labral denticle. Rear edge of anterior band very sharp and distinct. Anterior band subdivided into upper and lower parts by distinct fasciolar ridge. Both upper and lower bands very weakly evenly convex, nearly flat. Plication plate with deep and broad groove at upper third, separating adapical largest spiral ridge, and two slightly smaller ridges similar in size. Columella smooth. Aperture irregularly oval, rounded posteriorly due to callus, widest medially; outer lip medium thick, orthocline in side view, nearly straight, with slight, blunt labral denticle; siphonal notch shallow, symmetrically U-shaped. Colour uniformly white.

Radula ( $n=3$ ) (Fig. 13 D-F). Similar in all specimens. Central tooth tricuspid, with central cusp slightly longer than lateral ones. Cusps smooth, but lateral flaps strongly serrated and bearing longitudinal grooves between cusplets. 1-4 additional small cusplets between central and lateral major cusps.

\section{Remarks}

All sequenced specimens of $A$. alabaster sp. nov. are very similar to the holotype. In addition to pure white specimens, some are light ivory in colour of the upper teleoconch whorls or even of the entire shell (MNHN IM-2007-43583, Fig. 15C-D).

Conchologically Amalda alabaster sp. nov. is extremely similar to white specimens of A. montrouzieri. The slight differences may be the more regularly oval outline and the more cyrtoconoid spire of A. montrouzieri, but those differences are very subtle. The new species is recorded at larger depths than 
most of specimens of $A$. montrouzieri (180-210 versus 10-70 m), but A. montrouzieri can occasionally occur at the same depths as $A$. alabaster sp. nov.

Although A. montrouzieri and A. alabaster sp. nov. are closely related, a large genetic distance between them confirms their distinction. Furthermore, there appears to be a minor difference in the radula.

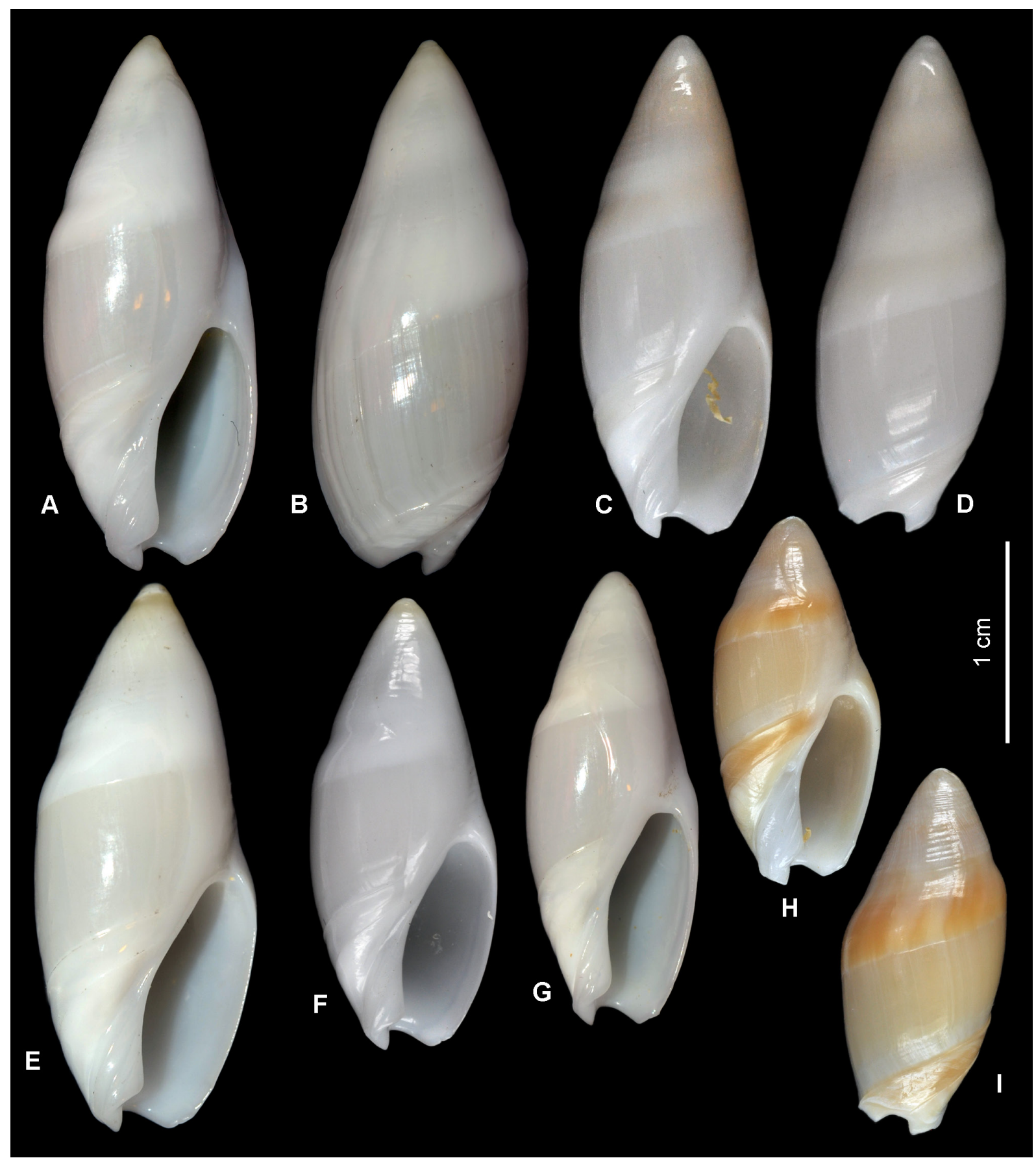

Fig. 15. Amalda alabaster sp. nov. A-B. Holotype, MNHN IM-2007-43627, SL 26.7 mm. C-D. MNHN IM-2007-43583, SL 24.8 mm. E. MNHN IM-2007-43621, SL 27.1 mm. F. MNHN IM-2007-43626, SL $22.2 \mathrm{~mm}$, specimen not sequenced. G. MNHN IM-2007-43633, SL $22 \mathrm{~mm}$, specimen not sequenced. H-I. A. cf. alabaster, MNHN IM-2013-63897, SL $18.1 \mathrm{~mm}$. Shells at the same scale, all specimens except $\mathrm{F}-\mathrm{G}$ sequenced. 
In A. montrouzieri the central cusp of the central tooth is clearly shorter than the lateral ones, but in A. alabaster sp. nov. the situation is opposite - the central cusp is distinctly longer. The illustration of the radula of $A$. montrouzieri by Kilburn \& Bouchet (1988: figs 51,53) shows a central tooth with a morphology similar to that in our A. alabaster sp. nov. Regrettably, the authors did not present the station data of the specimen from which the radula was extracted and, therefore, it is not clear whether they indeed examined A. montrouzieri. All our sequenced specimens originated from only two stations off south and south-eastern New Caledonia at depths of 180-210 m, but numerous non-sequenced specimens (see Material) were collected in the depth range of 237-298 m. Some have a light yellowish spire callus and upper anterior band.

One specimen (MNHN IM-2013-63897, Fig. 15H-I) from a station more to the North on the east coast of New Caledonia is sister to A. alabaster sp. nov., with a very high support. Conchologically it differs from A. alabaster sp. nov. in having a stouter shell with thicker primary callus and a more pronounced colouration. It may represent a geographical morph (although it was collected very close to the type locality of $A$. alabaster sp. nov.) or even a separate species, but at the moment the lack of additional sequenced material does not allow to draw firmer conclusions. So, we refer to this and similar specimens as $A$. cf. alabaster sp. nov. The ABGD analysis also attributed $A$. cf. alabaster sp. nov. to the same PSH as $A$. alabaster sp. nov.

\section{Distribution}

South-eastern New Caledonia, in 180-280 m.

Amalda allaryi Bozzetti, 2007

Figs 13G, 16A-F, 17A-B

Amalda allaryi Bozzetti, 2007: 14, text-fig.

Amalda maritzae Bozzetti, 2007: 15-16, text-fig [possible synonym; see Remarks].

Amalda allaryi - Gratecap 2014: 14, 19, figs 26-27.

\section{Type material}

\section{Holotype}

NEW CALEDONIA • Holotype of A. allaryi; Île des Pins; 250-280 m deep; MNHN IM-2000-20532

- Holotype of A. maritzae; "Norol Récifs" [but see below]; 250-280 m deep; MNHN IM-2000-24475.

\section{Material examined}

\section{Sequenced material}

3 sequenced specimens (Table 1).

\section{Not sequenced material}

NEW CALEDONIA - 2 dd; Grand Récif Sud; 22 $44^{\prime}$ S, 167¹9' E; 95-100 m deep; LAGON; stn DW580 • 3 dd; Canal de la Havannah; $22^{\circ} 13^{\prime}$ S, $167^{\circ} 07^{\prime}$ E; 264-273 m deep; EXBODI; stn CP3788

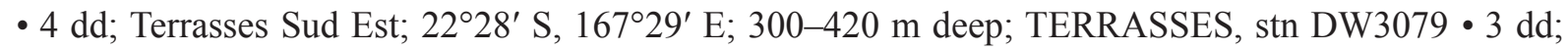
Terrasses Sud Est; $22^{\circ} 06^{\prime}$ S, $167^{\circ} 03^{\prime}$ E; 190-200 m deep; EXBODI; stn DW3093 • 1 dd; W of Île des Pins; $22^{\circ} 40^{\prime} \mathrm{S}, 167^{\circ} 12^{\prime} \mathrm{E}$; 219-244 m deep; KANACONO; stn CP4656 • 1 dd; W of Île des Pins; $22^{\circ} 41^{\prime} \mathrm{S}, 167^{\circ} 02^{\prime}$ E; $120-129$ m deep; KANACONO; stn DW4727 • 1 dd; S of Île des Pins; $22^{\circ} 47^{\prime}$ S, $167^{\circ} 27^{\prime}$ E; 244-285 m deep; KANACONO; stn CP4673 • 2 dd; W of Île des Pins; $22^{\circ} 42^{\prime}$ S, $167^{\circ} 13^{\prime}$ E; 303-315 m deep; KANACONO; stn CP4658 - 1 dd; E of Île des Pins; $22^{\circ} 41^{\prime}$ S, $167^{\circ} 41^{\prime}$ E; 358- 
393 m deep; KANACONO; stn CP4739 • 1 dd; W of Île des Pins; $22^{\circ} 41^{\prime} \mathrm{S}, 1^{\prime 6} 7^{\circ} 13^{\prime} \mathrm{E}$; $225-250 \mathrm{~m}$ deep; KANACONO; stn DW4701 • 5 dd; 1 lv (MNHN IM-2013-68272); SW of Île des Pins; $22^{\circ} 47^{\prime}$ S, $167^{\circ} 27^{\prime}$ E; 200-290 m deep; KANACONO; stn DW4695 • 13 dd; S of Île des Pins; $22^{\circ} 48^{\prime}$ S, $167^{\circ} 29^{\prime}$ E; 311-302 m deep; KANACONO; stn CP4674.

\section{Description}

SHELl. Large (SL up to $65 \mathrm{~mm}$ ), ovate-fusiform, with a cyrtoconoid spire. Primary spire callus thick, weakly microshagreened, covering all whorls, except 1-1.5 protoconch whorls, thus rendering impossible the whorls count and measurements. First protoconch whorl diameter 0.84-1.02 mm (mean $0.92, \mathrm{n}=3$ ). Secondary callus thick, fusing without visible border with parietal callus, with distinct anterior border and reaching anterpenultimate whorl. Plication plate with 2-3 ridges, lowest one the weakest, columella smooth. Olivoid groove very shallow, nearly obsolete, labral denticle very small, obtuse. Upper anterior band weakly convex, rear edge of anterior plate distinctly thickened, raised above the surface of upper anterior band, nearly flat. Lower anterior band nearly flat, smooth. Colour from very pale creamy to ivory. Primary callus from light to dark orange or brown, with strongly prosocline lighter axial lines. Secondary callus orange in upper part. Olivoid band slightly lighter than body whorl cloak, upper anterior band of the same colour as cloak, lower anterior band and plication plate white.

Radula (MNHN IM-2013-68272, Fig. 13G). Central tooth tricuspid, with central cusp slightly narrower and shorter than lateral ones. Cusps smooth, broad lateral flaps strongly serrated and with shallow longitudinal grooves between cusplets. 0-2 additional small cusplets between central and lateral major cusps.

\section{Remarks}

Amalda allaryi is very similar to coloured specimens of $A$. montrouzieri, with which it can be sympatric where they bathymetrically overlap. The morphological differences between the two are very subtle and include the generally more obtuse shell apex in A. allaryi, reflecting its larger protoconch (Fig. 17A-B), and a more brightly coloured callus, which can be orange-pink (as in our studied specimens) with narrow, dense, strongly prosocline lighter axial lines. In the holotype, though, the callus is much paler, light yellowish-brown. Nevertheless the molecular data confirm the distinctiveness of the two species.

Based on shell characters, Gratecap (2014) considered A. allaryi to be a form of A. montrouzieri, a conclusion rejected by our molecular data. He also illustrated additional specimens (Gratecap 2014: figs 29 - no locality provided, 30 - Île des Pins at $450 \mathrm{~m}, 31$ - no locality provided) as A. maritzae. The latter nominal species, which is known from the holotype only, is very similar to A. allaryi (Fig. 16G$\mathrm{H})$, differing in a larger and heavier shell and minor details of colouration. The stated type locality, "Norol reefs, northward of New Caledonia", is problematic. The place name "Norol reefs" is absent in New Caledonia, and the handwritten label accompanying the holotype in fact reads "Nord Récifs d'Entrecasteaux", to the north of New Caledonia, where we have not found A. allaryi. The holotype originated from a commercial source and the locality needs confirmation. It may represent a separate species or a disjunct population of $A$. allaryi. In the absence of molecular material, we conditionally synonymize the two species and as first revisers select $A$. allaryi as the valid name.

\section{Distribution}

Judging from sequenced and dead collected material, Amalda allaryi inhabits a narrow perimeter near Île des Pins at depths of 90 to $250-280 \mathrm{~m}$ (holotype) that lies completely within the range of $A$. montrouzieri (5-280 m). 


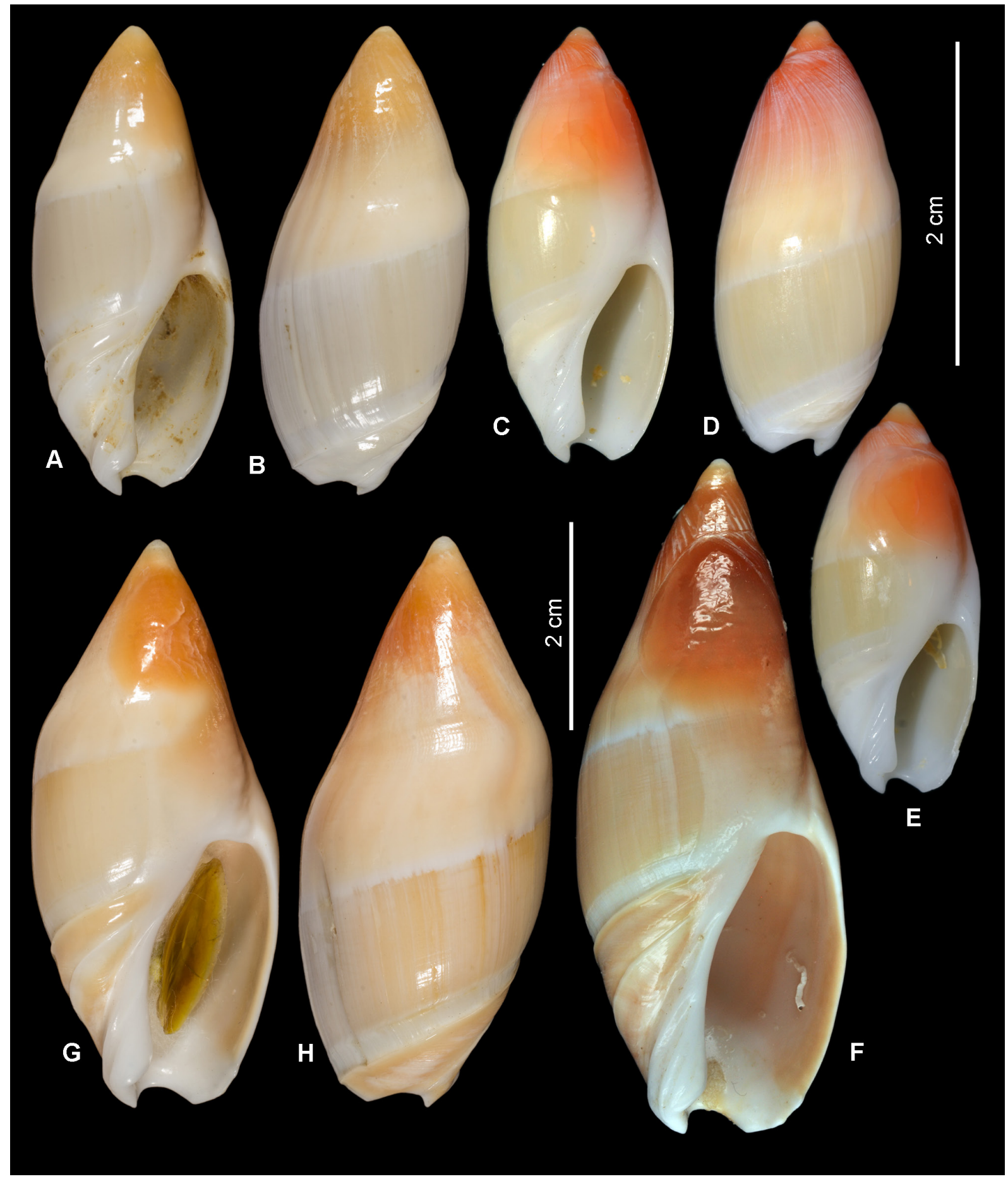

Fig. 16. A-F. Amalda allaryi Bozzetti, 2007. A-B. Holotype, MNHN IM-2000-20532, SL 29.4 mm. C-D. MNHN IM-2007-43630, SL 27.2 mm. E. MNHN IM-2007-43628, SL 24.4 mm. F. KANACONO, stn CP4656, 22 $2^{\circ} 40^{\prime} \mathrm{S}, 167^{\circ} 12^{\prime} \mathrm{E}, 219-244 \mathrm{~m}$, W of Île des Pins, SL $64.5 \mathrm{~mm}$. G-H. A. maritzae Bozzetti, 2007, holotype, MNHN IM-2000-24475, SL $54.4 \mathrm{~mm}$. A-E= at the same scale; F-H=at the same scale; $\mathrm{C}-\mathrm{E}=$ sequenced specimens. 
Amalda fuscolingua Kilburn \& Bouchet, 1988

Fig. 9B, 18A-E

Amalda fuscolingua Kilburn \& Bouchet, 1988: 288-289, figs 25-28, 40-41, 54.

Amalda fuscolingua - Gratecap 2014: 14, 18, figs 11-13.

\section{Type material}

\section{Holotype}

SOUTHERN NEW CALEDONIA • S of Île des Pins; $22^{\circ} 54^{\prime}$ S, $167^{\circ} 14^{\prime}$ E; $412-428$ m deep; SMIB 2; stn DW03; MNHN IM-2000-1439.

\section{Material examined}

\section{Sequenced material}

8 sequenced specimens (Table 1 ).

\section{Not sequenced material}

SOUTHERN NEW CALEDONIA • material listed by Kilburn \& Bouchet (1988) 1 dd; SW of Île des Pins; $22^{\circ} 56^{\prime} \mathrm{S}, 167^{\circ} 15^{\prime} \mathrm{E}$; $437 \mathrm{~m}$ deep; SMIB 3; stn DW25 • $1 \mathrm{dd}$; SW of Île des Pins; $22^{\circ} 46^{\prime} \mathrm{S}$, $167^{\circ} 11^{\prime} \mathrm{E}$; 394 m deep; SMIB 3; stn DW28 • 4 dd; SW of Île des Pins; $22^{\circ} 47^{\prime} \mathrm{S}, 167^{\circ} 12^{\prime} \mathrm{E}$; $405 \mathrm{~m}$ deep; SMIB 3; stn DW29 • 1 lv; 3 dd; between Île des Pins and Grand Récif Sud; $22^{\circ} 56^{\prime}$ S, $167^{\circ} 14^{\prime}$ E; 400 420 m deep; SMIB 4; stn DW65 • 1 dd; between Île des Pins and Grand Récif Sud; $22^{\circ} 56^{\prime}$ S, $167^{\circ} 15^{\prime}$ E; 400-430 m deep; SMIB 4; stn DW66 1 dd; between Île des Pins and Grand Récif Sud; $22^{\circ} 55^{\prime}$ S, $167^{\circ} 15^{\prime} \mathrm{E}$; 395-405 m deep; SMIB 4; stn DW69 • $15 \mathrm{lv}$, dd; E of Île des Pins; $22^{\circ} 51^{\prime}$ S-22 $2^{\circ} 52^{\prime}$ S, $168^{\circ} 12^{\prime}$ E-168 $13^{\prime}$ E; 408-436 m deep; SMIB 8; stn DW197-199 • 15 lv, dd; SE slope of Passe de Dumbéa; $22^{\circ} 52^{\prime} \mathrm{S}, 167^{\circ} 12^{\prime} \mathrm{E}$; $400 \mathrm{~m}$ deep; BATHUS 2; stn DW729 • $15 \mathrm{dd}$; S of Île des Pins; $22^{\circ} 44^{\prime} \mathrm{S}$, $167^{\circ} 17^{\prime}$ E; 350-393 m deep; BATHUS 2; stn DW717 • 3 dd; S of Île des Pins; $22^{\circ} 50^{\prime}$ S, $167^{\circ} 27^{\prime}$ E; 430-433 m deep; BATHUS 2; stn DW723 • 10 dd; S of Île des Pins; $22^{\circ} 48^{\prime} \mathrm{S}, 1^{\circ} 7^{\circ} 26^{\prime} \mathrm{E}$; $344-358 \mathrm{~m}$

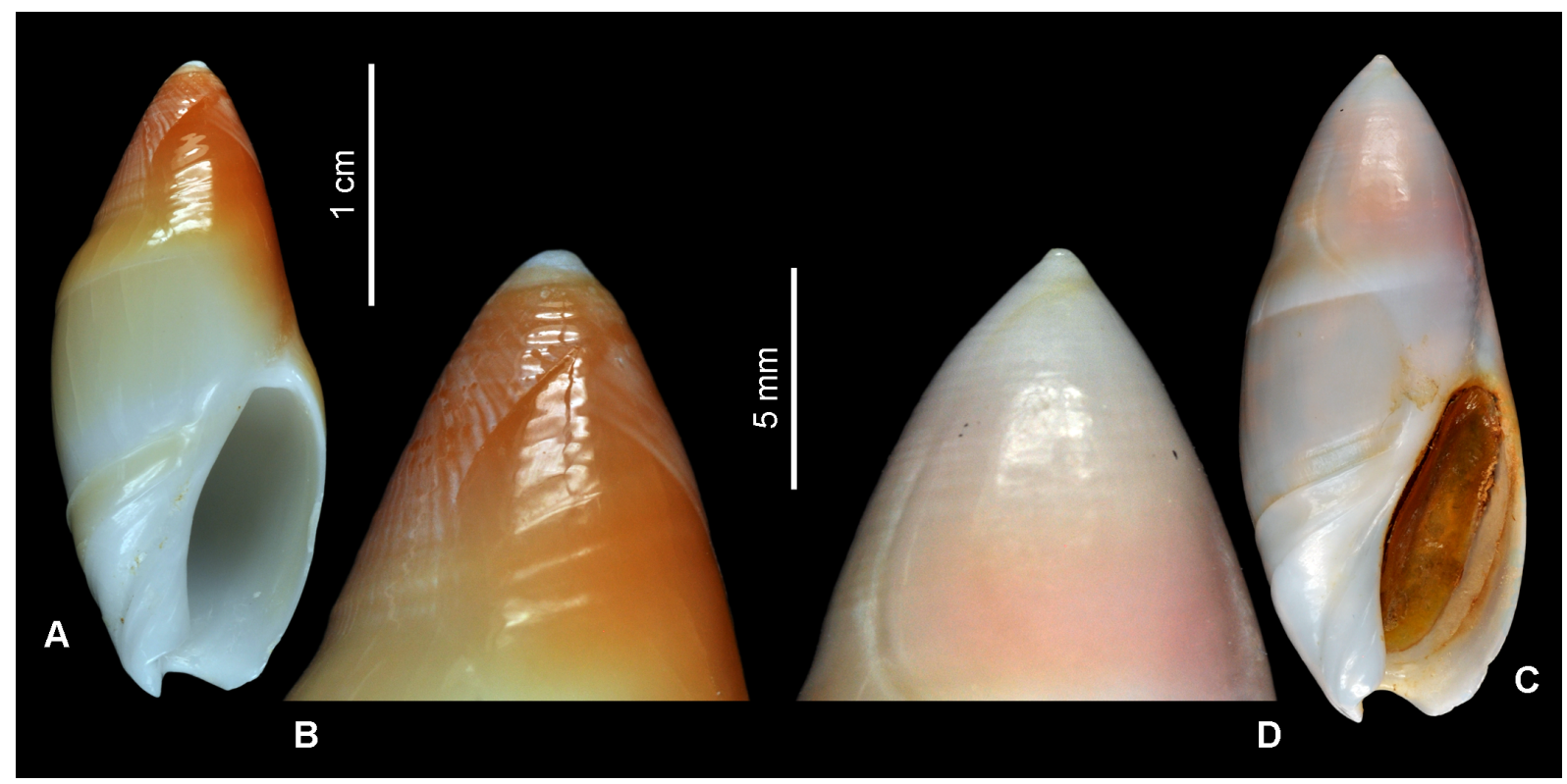

Fig. 17. Comparison of Amalda allaryi Bozzetti, 2007 with A. montrouzieri (Souverbie, 1860). A-B. A. allaryi, MNHN IM-2013-68272, SL $26.2 \mathrm{~mm}$, specimen not sequenced. C-D. A. montrouzieri, LAGON, stn DW51, Nouméa Sector, $22^{\circ} 15^{\prime} \mathrm{S}, 166^{\circ} 11^{\prime} \mathrm{E}, 10 \mathrm{~m}$, SL $27.6 \mathrm{~mm}$, specimen not sequenced. 
deep; BATHUS 2; stn DW724 • 6 dd; Canal de la Havannah; 22 ${ }^{\circ} 13^{\prime}$ S, $167^{\circ} 09^{\prime}$ E; 353-365 m deep; EXBODI; stn DW3784 • 1 dd; Canal de la Havannah; $22^{\circ} 15^{\prime}$ S, $167^{\circ} 10^{\prime}$ E; 386-387 m deep; EXBODI; stn DW3785 • 7 dd; SW of Île des Pins; $22^{\circ} 57^{\prime}$ S, 167¹6' E; 427-433 m deep; NORFOLK 1; DW1733 - 15 lv, dd; SW of Île des Pins; 22 ${ }^{\circ} 52^{\prime}$ S, $167^{\circ} 12^{\prime}$ E; 383-407 m deep; NORFOLK 1; stn DW1736 • ca 30 lv, dd; SW of Île des Pins; $22^{\circ} 51^{\prime} \mathrm{S}, 1^{\circ} 67^{\circ} 10^{\prime} \mathrm{E}$; $400 \mathrm{~m}$ deep; NORFOLK 1; stn DW1737; • $15 \mathrm{dd}$; SW of Île des Pins; $22^{\circ} 51^{\prime} \mathrm{S}, 167^{\circ} 12^{\prime} \mathrm{E}$; $340-381 \mathrm{~m}$ deep; NORFOLK 1; stn DW1738. - Off île des Pins • 10 dd; 22 44' S, $167^{\circ} 16^{\prime}$ E; 386-391 m deep; NORFOLK 2; stn DW2148 • 12 dd; $22^{\circ} 43^{\prime}$ S, $167^{\circ} 14^{\prime} \mathrm{E}$; 353-368 m deep; NORFOLK 2; stn DW2151 • 4 dd; $22^{\circ} 47^{\prime} \mathrm{S}, 167^{\circ} 12^{\prime} \mathrm{E}$; 395-400 m deep; NORFOLK 2; stn CP2153 • 25 dd; 22 $2^{\circ} 4^{\prime}$ S, $167^{\circ} 15^{\prime}$ E; 468-500 m deep; NORFOLK 2; stn DW2156• $1 \mathrm{lv} ; 22^{\circ} 45^{\prime} \mathrm{S}, 1_{167^{\circ}} 13^{\prime} \mathrm{E}$; 400-405 m deep; KANACONO; stn DW4660; MNHN IM-2013-68426 • 2 lv; $22^{\circ} 57^{\prime} \mathrm{S}, 167^{\circ} 39^{\prime} \mathrm{E}$; 310-403 m deep; KANACONO; stn DW4745; MNHN IM-2013-63419; MNHN IM-2013-63425.

\section{Description}

MEAsurements. Shell large (SL up to $57 \mathrm{~mm}$ ).

SHELL. Ovate-fusiform, with blunt orthoconoid spire. Primary spire callus thick, microshagreened, covering all whorls, except 1-1.5 protoconch whorls. First protoconch whorl diameter 0.92-1.06 mm (mean $0.98, n=5$ ). Secondary callus thick, fusing without visible border with parietal callus, with distinct anterior border, reaching suture of antepenultimate whorl. Plication plate with 3-6 ridges, all weak except outer 2, columella smooth. Olivoid groove very shallow to obsolete, labral denticle very small, obtuse to absent. Upper anterior band nearly flat except weak submedian low ridge. Lower anterior band nearly flat, microshagreened. Primary callus orange-brown in lower part, brown on spire with distinct, strongly prosocline, lighter axial lines. Secondary callus orange-brown. Body whorl cloak light yellowish-brown, olivoid band usually slightly lighter, anterior band orange brown with upper anterior band slightly darker, of the same colour as cloak, plication plate white.

\section{Remarks}

This distinct species poses no taxonomic problems due to its very characteristic colour pattern of primary spire callus with strongly prosocline lighter axial lines and brightly coloured thick orangebrown secondary callus. There is no species in New Caledonia resembling A. fuscolingua.

The radula, examined by Kilburn \& Bouchet (1988: fig. 54), is similar to that of A. montrouzieri with central tooth with less serrated cusps.

\section{Distribution}

The species is confined to a narrow perimeter around Île des Pins (Fig. 9B), with a maximal extension of $150 \times 60 \mathrm{~km}$ and a depth range of $300-500 \mathrm{~m}$.

Amalda coriolis Kilburn \& Bouchet, 1988

Figs $13 \mathrm{H}, 18 \mathrm{~F}-\mathrm{J}$

Amalda coriolis Kilburn \& Bouchet, 1988: 293, figs 33-37, 42-43, 58.

Amalda coriolis - Gratecap 2014: 14, 19, figs 14-15.

\section{Type material}

Holotype

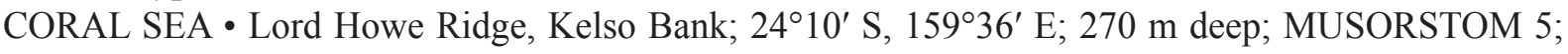
stn DW280; MNHN IM-2000-1393. 


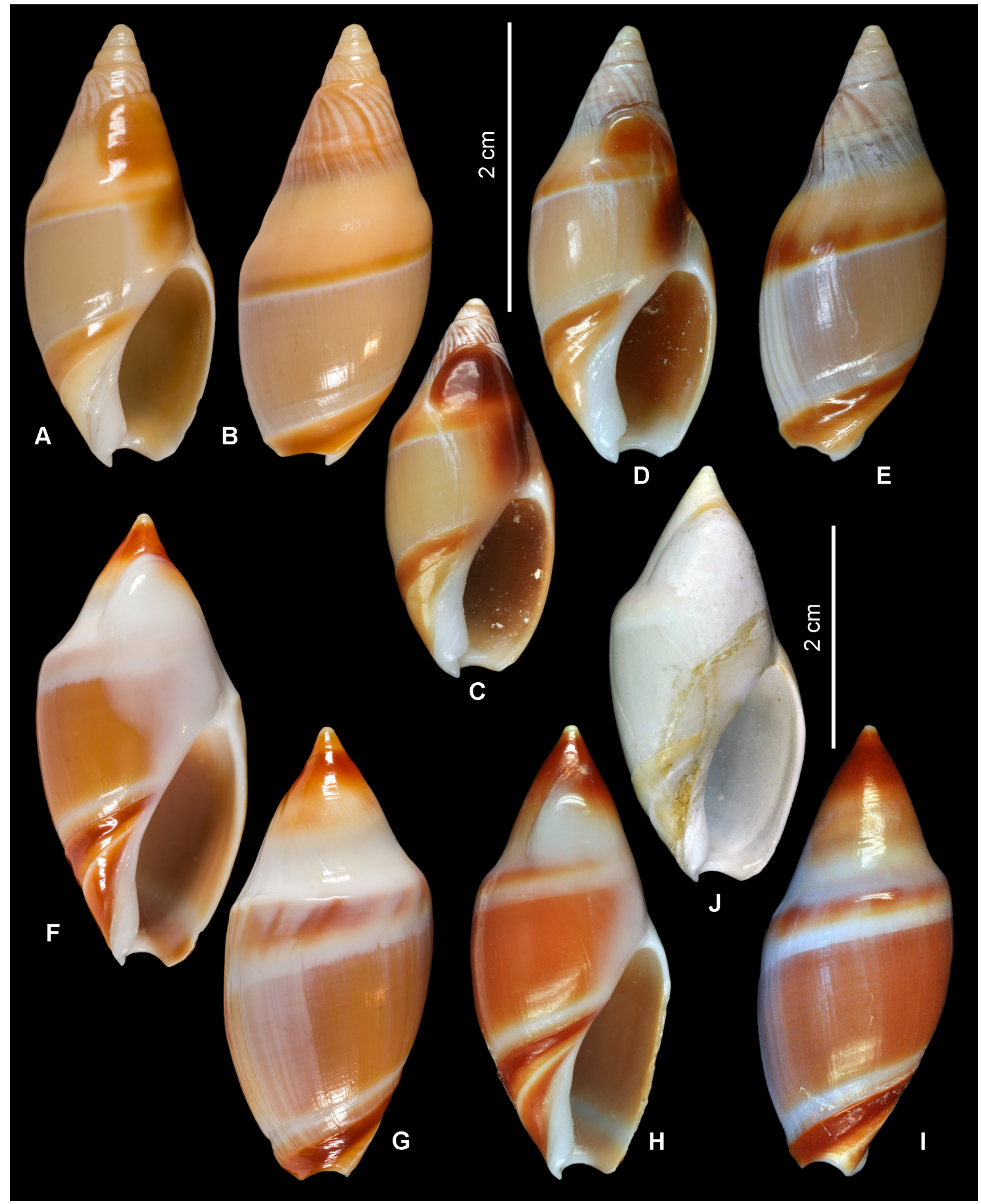

Fig. 18. A-E. A. fuscolingua Kilburn \& Bouchet, 1988. A-B. Holotype, MNHN IM-2000-1439, SL $30.6 \mathrm{~mm}$. C. MNHN IM-2007-43643, SL $26.6 \mathrm{~mm}$ (sequenced specimen). D-E. MNHN IM-200743649, SL 30.2 mm (sequenced specimen). F-J. A. coriolis Kilburn \& Bouchet, 1988. F-G. Holotype, MNHN IM-2000-1393, SL 40.1 mm. H-I. MNHN IM-2013-63899, SL 40.4 mm (sequenced specimen).

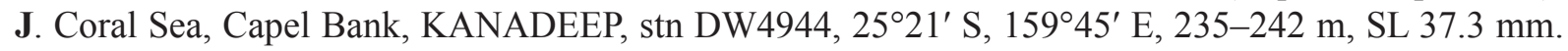
$\mathrm{A}-\mathrm{E}=$ at the same scale; $\mathrm{F}-\mathrm{J}=$ at the same scale. 


\section{Material examined}

\section{Sequenced material}

Two sequenced specimens (Table 1).

\section{Not sequenced material}

CORAL SEA • Material listed by Kilburn \& Bouchet (1988) 1 dd; Capel Bank; 250' S, $159^{\circ} 50^{\prime}$ E; 270 m deep; KANADEEP 1; stn CP4928 • 9 dd; Capel Bank; 2521' S, 159 45' E; 235-242 m deep;

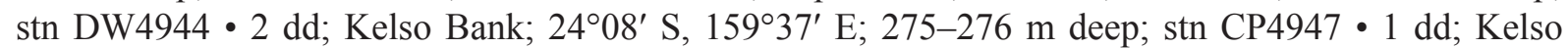
Bank; $24^{\circ} 07^{\prime} \mathrm{S}, 159^{\circ} 40^{\prime} \mathrm{E}$; $275 \mathrm{~m}$ deep; stn CP4948 • 1 dd subadult; Kelso Bank; $24^{\circ} 12^{\prime} \mathrm{S}, 159^{\circ} 41^{\prime} \mathrm{E}$; 270-385 m deep; stn DW4951.

\section{Description}

MEAsurements. Shell large (SL up to $48.9 \mathrm{~mm}$ ).

SHELL. Biconic-ovate, with narrow base and high, acutely conical spire. Last whorl angulated just below suture. Primary spire callus thick, microshagreened, covering all whorls, except $1-1.5$ protoconch whorls, with very weak spiral ridges. Protoconch large, low-dome shaped, first whorl diameter 0.95$1.13 \mathrm{~mm}$ (mean 1.06, $\mathrm{n}=5$ ). Secondary callus very thick, fusing without visible border with parietal callus, with distinct anterior border, forming a strong pad reaching adapical suture of antepenultimate whorl. Plication plate with 1-4 ridges, all weak except adapical one, columella smooth. Olivoid groove distinct, labral denticle not pronounced. Upper anterior band weakly convex, with rounded and weak submedian low ridge. Lower anterior band nearly flat, microshagreened. Primary callus from very light yellowish to dark orange-brown in upper part, in the lower part with white to creamy spiral band. Secondary callus white to creamy. Body whorl cloak from white to orange, olivoid band nearly white, upper anterior band from yellowish to dark brown and lower anterior band from white to orange-brown, plication plate white.

RADULA (Fig. 13H). Examined in one specimen. Central tooth tricuspid, with broad lateral flaps, central cusp slightly narrower and shorter than lateral ones. Central cusp nearly smooth, lateral ones slightly serrated, broad lateral flaps strongly serrated with indistinct longitudinal grooves situated between cusplets.

\section{Remarks}

The radula illustrated by Kilburn \& Bouchet (1988: fig. 58) is very similar to our specimen.

This very characteristic species is readily distinguished from all other species in New Caledonia by its shell shape. Although the holotype is dark coloured, most specimens are much lighter, sometimes even pure white (Fig. 18J). The upper anterior band is the last shell zone that loses colour.

\section{Distribution}

The species is a narrow endemic found only on Kelso and Capel banks in the Coral Sea at depths of $150-275 \mathrm{~m}$.

Amalda sp.

Figs 19A-B, 20A

\section{Material examined and sequenced}

PAPUA NEW GUINEA • 1 lv; Manus I; 02¹0' S, 147 16’ E; 200-219 m deep; BIOPAPUA; stn DW3694; MNHN IM-2013-63891. 


\section{Remarks}

Radula ( $n=1$, Fig. 20A) with tricuspid central tooth, with medium broad lateral flaps, central cusp 1.5 times narrower and shorter than lateral ones. Cusps nearly smooth, while lateral flaps are strongly serrated with shallow longitudinal grooves situated between cusplets. 1-2 additional minute cusplets on both sides of central cusp.

In the molecular tree, this seemingly subadult specimen was recovered as sister to Amalda cacao sp. nov. In shell appearance it resembles a miniature $A$. hilgendorfi, although with thinner and uncarinated spire callus, which is much less microshagreened than in A. hilgendorfi. Judging from the molecular tree, this specimen clearly represents a new species, but we abstain from description pending the collection of additional material including adult specimens.

Amalda monilifera (Reeve, 1864)

Figs 19F-G, 20B, E

Ancillaria monilifera Reeve, 1864: pl. 10, sp. 36.

Gracilispira monilifera - Wilson 1994: 131, pl. 29, fig. 16 a-c.

Amalda (Gracilispira) monilifera - Gratecap 2016a: 6, 18, fig. 12.

\section{Type material}

Holotype (by monotypy)

WESTERN AUSTRALIA • Swan River; NHMUK 197933.

\section{Material examined}

One sequenced specimen (Table 1).

\section{Description}

Measurements. Shell small (SL up to $18 \mathrm{~mm}$ ).

SHELl. Ovate-fusiform, with conical spire with nearly straight sides. Primary spire callus thin, semitransparent, smooth, covering all whorls, except protoconch. Protoconch rounded above, boundary with teleoconch indistinct, first whorl diameter $0.65 \mathrm{~mm}$. Secondary callus medium thick on parietal wall and forming distinct parietal pad, extending only to penultimate whorl. Plication plate with 3 weak ridges and still two weaker on columella. Olivoid groove distinct but shallow, labral denticle prominent, narrow triangular. Upper anterior band weakly convex, with low median ridge, lower anterior band nearly flat, smooth. Colour of primary callus light orange, body whorl cloak creamy with light brown anastomosing pattern, subsuturally a row of large, irregular oval brown spots, seen through transparent callus on all teleoconch whorls, olivoid band and lower anterior band with row of brown spots, plication plate creamy.

Radula (n=1, Fig. 20B, E). With broad, subtriangular lateral teeth with sharp, hook-shaped, curved tip. Central cusp multicuspid, with three major central cusps, median much narrower and slightly shorter than lateral ones, in addition medium long, irregularly shaped, 2-4 cusps between lateral and median cusps, also irregular-shaped fissures in median part of central tooth. Lateral flaps of central tooth dentated, with $3-5$ triangular short cusplets.

\section{Remarks}

The radula of the species is studied here for the first time. 


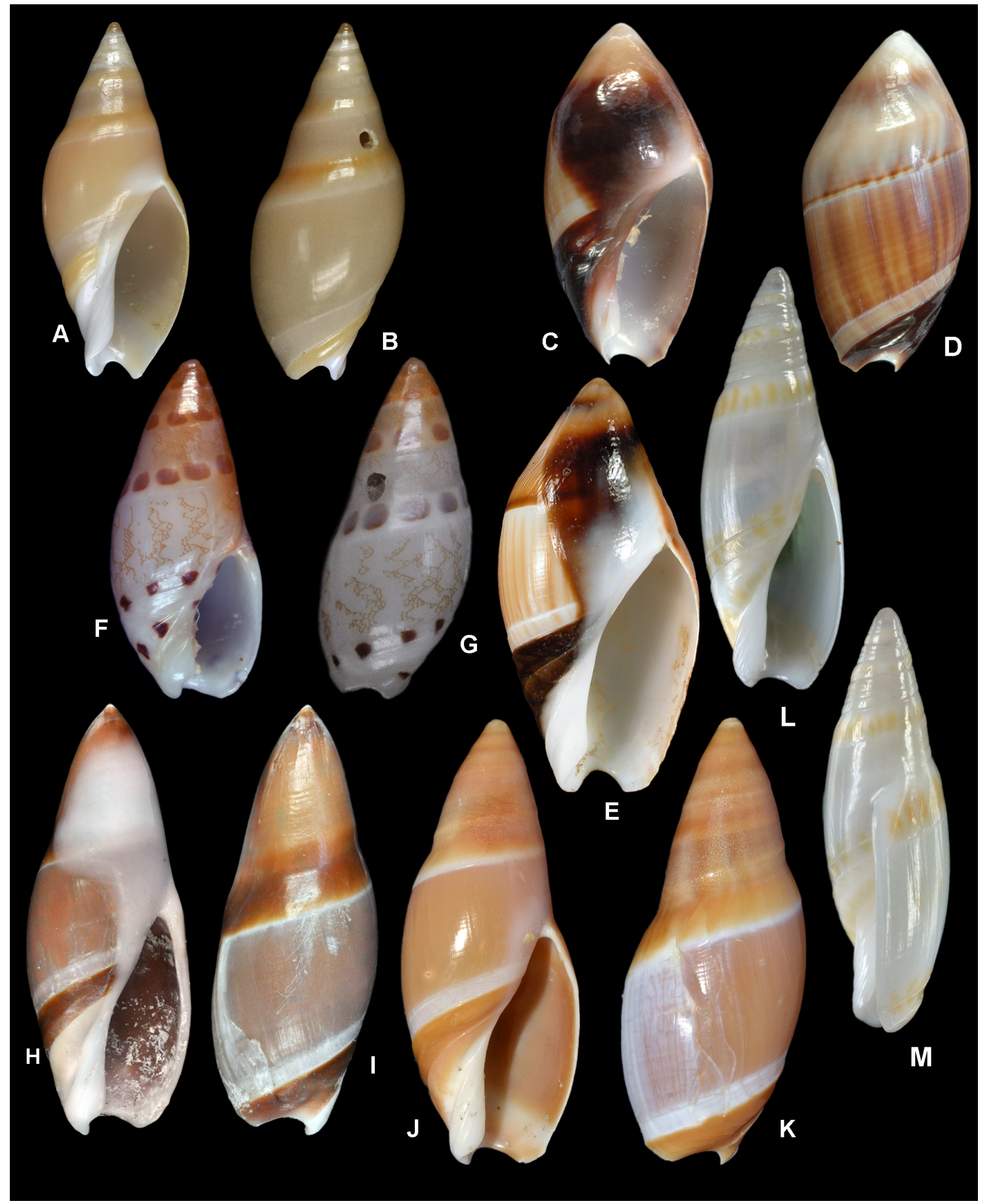

Fig. 19. Sequenced species of Amalda H. Adams \& A. Adams, 1853. A-B. Amalda sp., MNHN IM2013-63891, SL 20 mm. C-D. A. contusa (Reeve, 1864), MNHN IM-2009-22263, SL 24.9 mm. E. A. optima (G.B. Sowerby III, 1897), MNHN IM-2007-38287. F-G. A. monilifera (Reeve, 1864), MNHN IM-2013-63898, SL 11.7 mm. H-I. A. hinomotoensis (Yokoyama, 1922), MNHN IM-2019-618, SL41.4 mm. J-K. A. hayashii Ninomiya, 1988, MNHN IM-2013-44413, SL 38.4 mm. L-M. A. bellonarum Kilburn \& Bouchet, 1988, MNHN IM-2007-33273. Shells not to scale. 
Ninomiya (1990) included this species in his new subgenus Mundaspira (type species Amalda concinna Ninomiya, 1990).

\section{Distribution}

The Recherche Archipelago in southern Western Australia (Gratecap 2016a), in 0-15 m.
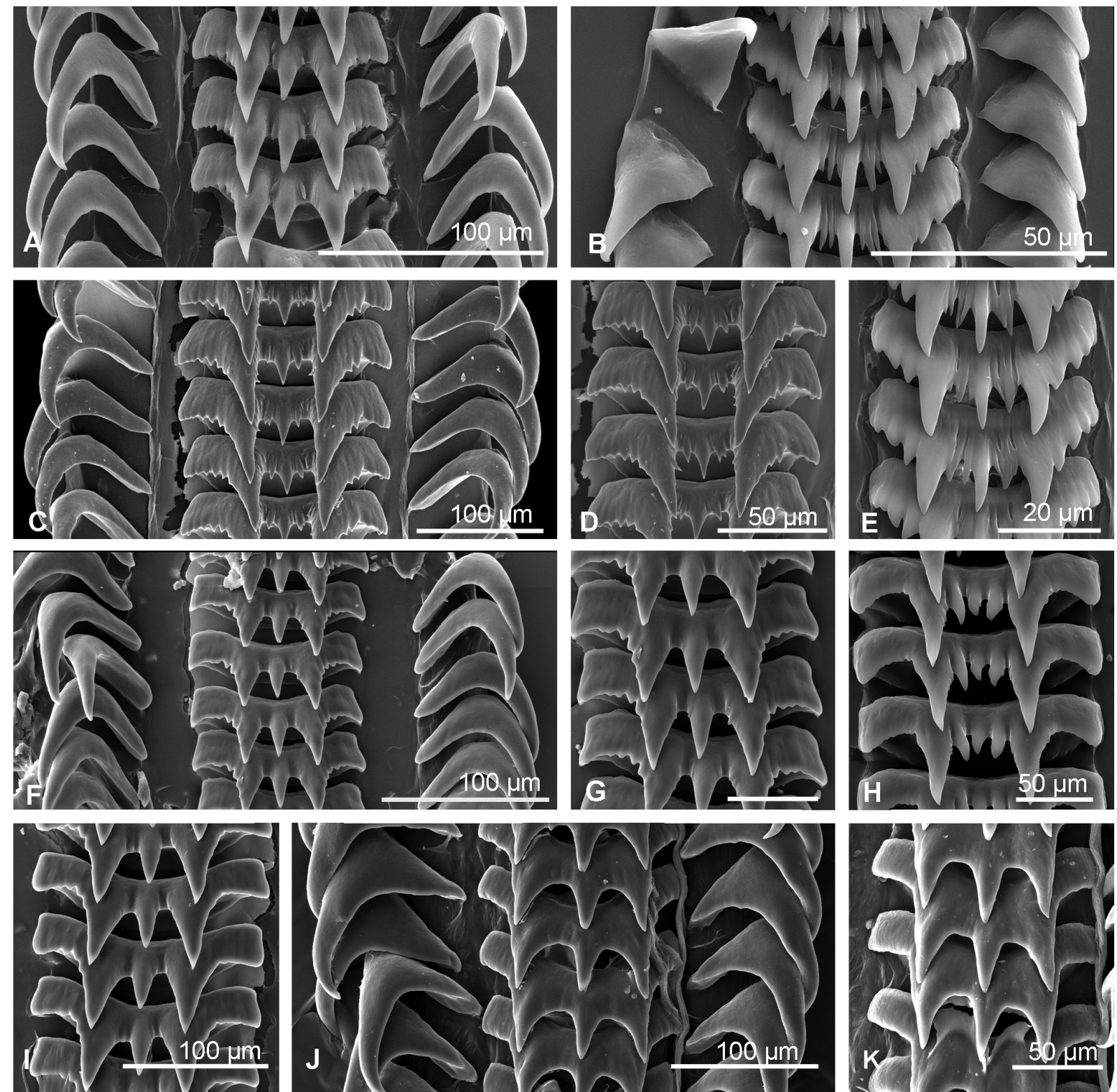

Fig. 20. Radulae of species of Amalda H. Adams \& A. Adams, 1853. A. Amalda sp., MNHN IM-201363891 (shell on Fig. 19A-B). B, E. A. monilifera (Reeve, 1864), MNHN IM-2013-63898 (shell on Fig. 19F-G). C-D. A. contusa, MNHN IM-2009-22264, SL 22.7 mm. F-I. A. hayashii Ninomiya, 1988. F-G. MNHN IM-2013-44413 (shell on Fig. 19J-K). H. MNHN IM-2013-44432. I. MNHN IM-201344457, SL 38.2 mm. J-K. A. hinomotoensis (Yokoyama, 1922), MNHN IM-2019-619, SL 38.5 mm. 
Amalda hinomotoensis (Yokoyama, 1922)

Figs 19H-I, 20J-K

Ancilla hinomotoensis Yokoyama, 1922: 48, pl. 2 fig. 5.

Ancilla hinomotoensis - Taki \& Oyama 1954: pl. 22 figs 5-5a.

Baryspira urasima Is. Taki ms - Kira 1959: 63, pl. 31 fig. 3.

Amalda hinomotoensis - Tsuchida 2017: 332, pl. 288 fig. 5, 996. — Gratecap 2016b: 5, 13, figs 11-13. Amalda urasima - Okutani 2000: 523, pl. 260 fig. 5.

\section{Type material}

\section{Lectotype}

JAPAN - lectotype of Ancilla hinomotoensis (designated by Taki \& Oyama 1954); Pliocene of Shito; UMUT 20840.

\section{Material examined}

Two sequenced specimens (Table 1).

\section{Description}

Measurements. Shell medium in size (SL exceeding $41 \mathrm{~mm}$ ).

SHELl. Narrow to ovate-fusiform, with a weakly cyrtoconoid spire. Primary spire callus thick, microshagreened, covering all whorls except protoconch tip, rendering measurements impossible. Secondary callus thick, strongly microshagreened and mat, fusing without visible border with parietal callus, with distinct anterior border and nearly reaching shell tip. Plication plate with up to 5 ridges subdivided by grooves, or nearly smooth, columella smooth. Olivoid groove shallow to very shallow, labral denticle very short, obtuse. Anterior band strongly microshagreened, upper anterior band very weakly convex, lower anterior band flat. Primary callus orange-brown in middle part, lighter abapically, bordered by very thin, light spiral line. Secondary callus white. Body whorl cloak light chestnut, olivoid band whitish, upper anterior band dark brown, lower anterior band creamy, plication plate white.

Radula ( $\mathrm{n}=1$, Fig. 20J-K). With hook-shaped lateral teeth with broad bases. Central tooth tricuspid with subequal, large, triangular, smooth cusps and medium broad lateral flaps.

\section{Remarks}

The name Baryspira urasima was introduced by Kira (1959) without description and despite its use by Okutani (2000), it remains an unavailable name (ICZN art. 13.1.1).

\section{Distribution}

Japan, from Sagami Bay to Kyushu, in 200-350 m (Tsuchida 2017).

Amalda hayashii Ninomiya, 1988

Figs $19 \mathrm{~J}-\mathrm{K}, 20 \mathrm{~F}-\mathrm{I}$

Amalda (Alcospira) hayashii Ninomiya, 1988: 145, pl. 1 figs 7-8.

Amalda hayashii-Okutani 2000: 523, pl. 260, fig. 3 (erroneously labelled as A. hilgendorfi). - Tsuchida 2017: atlas: 332, pl. 288 fig. 2, text: 995. 


\section{Type material}

\section{Holotype}

SOUTHERN JAPAN • Amami-Oshima Island; Ninomiya collection [not seen].

\section{Material examined}

9 sequenced specimens (Table 1).

\section{Description}

Measurements. Shell medium in size (SL up to $50 \mathrm{~mm}$ ).

Shell. Ovate-fusiform, with medium high, weakly cyrtoconoid spire. Primary spire callus thick, strongly pustulose except smooth last whorl, covering all whorls, except tip of protoconch, rendering measurements impossible. Secondary callus rather thin, with indistinct borders, microshagreened, weakly glossy, fusing with parietal callus without visible border, and reaching antepenultimate whorl and merging into primary callus. Plication plate from nearly smooth to bearing up to 5 ridges, columella smooth or with traces of plicae. Olivoid groove shallow to very shallow, labral denticle short, obtuse, rounded. Anterior band microshagreened, upper anterior band weakly convex with median or shifted more abapically, obtuse ridge, lower anterior band flat. Primary callus yellow-brownish on spire and slightly darker abapically, also bordered by almost white, medium broad, band. Secondary callus whitish, translucent. Body whorl cloak light chestnut with slight purple tint, olivoid band whitish, anterior brown, lower anterior band lighter, plication plate creamy.

Radula ( $\mathrm{n}=3$, sequenced, Fig. 20F-I). With simple, hook-shaped lateral teeth. Central teeth quite variable, from tridentate with large, smooth cusps, central smallest (Fig. 20I), with serrated cusps and lateral flaps (Fig. 20G), to multicuspid central with five smooth cusps, central three much smaller than lateral ones.

\section{Distribution}

From southern Japan to the South China Sea, in 250-310 m.

Amalda contusa (Reeve, 1864)

Figs 19C-D, 20C-D

Ancillaria contusa Reeve, 1864: pl. 9, species no. 31.

Amalda contusa - Gratecap 2012: 19, 27, figs 1-2 (holotype illustrated), 3-5.

Amalda cf. contusa - Gratecap 2012: figs 9-10.

\section{Type Material}

Holotype

Holotype by monotypy; locality unknown; NHMUK 197836.

\section{Material examined}

Three sequenced specimens (Table 1).

\section{Description}

Measurements. Shell small (SL up to $25 \mathrm{~mm}$ ). 
SHELL. Broadly ovate, with narrow base and low conical spire. Primary spire callus very thick, smooth and glossy, covering all whorls, except tip of protoconch, rendering measurements impossible. Secondary callus rather thick, with distinct anterior border, smooth and glossy, fusing without visible border with parietal callus, and reaching shell apex. Plication plate smooth, separated from anterior band by broad and deep groove, columella smooth. Olivoid groove shallow but distinct, labral denticle short, obtuse. Anterior band smooth, upper and lower anterior bands weakly convex. Primary callus milky-caramel with irregularly positioned sinuous, brownish axial lines, abapically bordered by interrupted narrow spiral, brown and lighter narrow lines. Secondary callus dark brown, turning very light above aperture. Body whorl cloak background caramel with irregularly spaced, orthocline, brown axial bands of uneven width and lighter spiral colour lines, olivoid band much lighter than cloak, of same tint, anterior band very dark brown, light brown near columella, very light brownish abapically.

Radula ( $\mathrm{n}=1$, sequenced, Fig. 20C-D). With rather short, hook-shaped lateral teeth. Central tooth broad, with broad lateral flaps, and three major cusps, median more than twice shorter and narrower than lateral ones. Lateral cusps serrated at their base as well as lateral flaps. 1-4 additional, smaller, irregularly shaped cusps between median and lateral major cusps.

\section{Remarks}

Our sequenced specimens correspond to what was treated and illustrated by Gratecap (2012: figs 9-10) as $A$. cf. contusa. This author also provided a lengthy discussion of the complex taxonomic history of A. contusa and concluded that there may be two similar but separate species, one in Natal, and the other in Mozambique and Natal. At present, the lack of comparative material does not allow us to clarify the situation and we provisionally consider our specimens to be the true A. contusa.

\section{Distribution}

KwaZulu Natal and Mozambique, in 15-20 m.

Amalda optima (G.B. Sowerby III, 1897)

Fig. 19E

Ancilla optima Sowerby III, 1897: 7, pl. 6 fig. 31.

Amalda optima - Gratecap 2012: 23, 29, fig. 23.

\section{Type material}

Possible syntype

SOUTH AFRICA・Durban; NHMUK 1899.4.14.648.

\section{Material examined}

One sequenced specimen (Table 1).

\section{Description}

MEAsurements. Shell large (SL up to $55 \mathrm{~mm}$ ).

SHELL. Broadly ovate, with narrow base and low conical spire. Primary spire callus very thick, smooth and glossy, covering all whorls, except tip of protoconch, rendering measurements impossible. Secondary callus rather thick, with distinct anterior border, smooth and glossy, fusing without visible border with parietal callus, and reaching the shell apex. Plication plate smooth, poorly separated from anterior band, columella smooth. Olivoid groove distinct, labral denticle very short, obtuse. Anterior band smooth, 
upper anterior band nearly flat, lower anterior band weakly convex. Primary callus milky-caramel with distinct sinuous, narrow brown axial lines, particularly pronounced on last whorl, its narrow spiral brown line bordered abapically by lighter, narrow line. Secondary callus caramel to dark brown, turning very light, nearly white, above aperture. Body whorl cloak background light caramel with irregularly spaced, orthocline, brown axial bands of uneven width, olivoid band much lighter than cloak, creamy-coloured, anterior band very dark brown.

RADULA. Not studied.

\section{Distribution}

Natal to Mozambique.

Amalda bellonarum Kilburn \& Bouchet, 1988

Fig. 19L-M

Amalda bellonarum Kilburn \& Bouchet, 1988: 290, 292, figs 29-32, 48-49.

Amalda (Alocospira) bellonarum - Gratecap 2014: 14, 19, figs 17-18.

\section{Type material}

\section{Holotype}

CORAL SEA • Bellona Plateau; $21^{\circ} 25^{\prime} \mathrm{S}, 159^{\circ} 09^{\prime} \mathrm{E}$; $60 \mathrm{~m}$ deep; CHALCAL; stn D56; MNHN IM2000-1112.

\section{Material examined}

One sequenced specimen (Table 1).

\section{Description}

MEASUREMENTS. Shell small (SL up to $15 \mathrm{~mm}$ ).

SHELl. Oblong-fusiform, with high spire. Primary spire callus not thick, glossy, covering all whorls, including most of protoconch rendering measurements inaccurate, and with distinct spiral lirae (6-7 on penultimate whorl). Secondary callus thin, with indistinct borders, narrow, nearly reaching antepenultimate whorl. Plication plate with 3-4 ridges. Olivoid groove deep and distinct, labral denticle weak, obtuse. Anterior band poorly separated in narrower upper anterior band and twice broader lower band, both nearly flat. Colour uniformly greyish-white with rows of faint yellow-orange spots, one subsutural and one on olivoid band and anterior band.

RADULA. Unknown.

\section{Remarks}

The only studied specimen from north Bellona Plateau, collected close to the type locality, differs from the types in having significantly more slender shell, although similar in other details. Besides, that specimen was collected at a significantly larger depth (324-330 m vs 45-240 m).

\section{Distribution}

Chesterfield-Bellona Plateau, Coral Sea, New Caledonia, at about 45-240 m. 


\section{Discussion}

The new molecular data confirm the validity of most nominal taxa described from New Caledonia except the status of Amalda hilgendorfi richeri, while the status of A. maritzae remains doubtful. In addition to those treated herein, one seemingly valid species has been described from south-west of Caledonia (Passe de Kouaré) in depths of 250-400 m - Amalda herberti Cossignani, 2013. We did not have in our possession specimens of the species, but the photo of the shell and live animal were made available by David Massemin (Fig. 14C-E). When the two new species described herein are considered, the fauna of Amalda of New Caledonia and the Coral Sea thus now includes at least 10 species, all but one (Amalda hilgendorfi) endemic to this region (see, however, the remarks under A. montrouzieri). Amalda cacao sp. nov. and A. hilgendorfi are broadly distributed in the New Caledonia EEZ, while A. bellonarum and A. coriolis are found only in the Coral Sea, and A. alabaster sp. nov., A. fuscolingua, A. allaryi, A. montrouzieri, A. herberti and A. aureomarginata are confined to southern New Caledonia (the range of the latter species now restricted based on molecular data).

Most New Caledonian species of Amalda have a narrow distributional range, but may be common within their range (Fig. 9), such as A. fuscolingua and A. aureomarginata which are known from hundreds of specimens. By contrast, A. hilgendorfi exhibits a remarkably broad distribution now confirmed by molecular data, and is known from Japan, the Philippines, Papua New Guinea, the Solomon Islands, New Caledonia and probably northern Australia (Gratecap 2016a). It is not clear why this species in particular is so broadly distributed in comparison to the other species of the genus. Its protoconch is not much different from that of other species examined (Table 2) and is similar in size to the protoconch of the narrow range endemic $A$. aureomarginata, restricted to southern New Caledonia. Nothing is known about the egg cases and larval development of any deep-water Amalda species. Kilburn \& Bouchet (1988: 298) speculated that, "the paucispiral protoconch in such cases reflects not holobenthic development with intracapsular metamorphosis, but lecithotrophic larval development with a short free-swimming larval phase". Thirty years later, this hypothesis remains mere speculation. Our data on the protoconchs of different Amalda did not reveal any correlation between the distributional range and protoconch size (Table 2). In species with paucispiral protoconchs, the larger protoconch suggests a longer intracapsular development (or direct development) and as a result the absence of long living planktonic larvae. In species of Amalda with narrow and very narrow ranges, both largest (A. miriky sp. nov.) and smallest (A. monilifera) protoconchs were found. But it should also be emphasized that, since protoconchs are covered by the callus, we were able to measure the diameter of the first whorl only, which may not be a reliable proxy for actual protoconch size.

In general, species of Amalda (shallow and deep water), however, have rather narrow ranges, as reviewed by Gratecap for different parts of the Indo-Pacific, where local faunas are usually dominated by narrow endemics (especially that of South Africa and, to a lesser extent, Australia). Although there are species with broader distributions extending, e.g., from Japan to Taiwan (A. hinomotoensis) or Indonesia, the Strait of Malacca, Vietnam and the China Sea (A. mamillata) (Gratecap 2016b), such distributions should be taken with caution, as exemplified by $A$. miriky sp. nov., previously considered a form or subspecies of $A$. hilgendorfi, but shown by molecular data to be a distinct although morphologically similar, species.

With our dataset being very patchy and relying on a single genetic marker, having limited validity of phylogenetic inferrence at the supraspecific level, we did not address the validity of the subgenera recognized within Amalda. Nevertheless, our observations are in line with the conclusions made by Gemmel et al. (2020), who analyzed the Amalda from New Zealand and several Indo-Pacific locations based on the entire mitogenome and long nuclear rRNA gene cassette data. Amalda australis (type species of Baryspira) is the sister species to A. novaezelandiae (type species of Gracilispira), while other species, attributed to Baryspira (A. mucronate) and to Gracilispira (A. benthicola) form a polytomy. Thus we agree with Gemmel et al. (2020) that the status of at least these two subgenera is not resolved. Both 
Table 2. Size of the protoconchs of the studied species.

\begin{tabular}{lcll}
\hline Species & $\begin{array}{c}\mathbf{N}^{\circ} \text { of studied } \\
\text { specimens }\end{array}$ & $\begin{array}{c}\text { First protoconch whorl } \\
\text { diameter, mm }\end{array}$ & $\begin{array}{c}\text { Distribution } \\
\text { range }\end{array}$ \\
\hline Amalda hilgendorfi & & $0.75-0.92 \mathrm{~mm}$ & Very broad \\
Japan morph & 3 & $0.8-0.92($ mean 0.88$)$ & \\
Coral Sea morph & 5 & $0.75-0.92($ mean 0.82$)$ & \\
Northern New Caledonia morph & 5 & $0.80-0.84($ mean 0.83$)$ & \\
Southern New Caledonia morph & 5 & $0.84-0.90$ (mean 0.86) & \\
Amalda aureomarginata & 5 & $0.88-0.94$ (mean 0.91$)$ & Very narrow \\
Amalda miriky sp. nov. & 3 & $1.15-1.25$ (mean 1.23) & Narrow \\
Amalda cacao sp. nov. & 1 & 0.68 & Medium broad \\
Amalda alabaster sp. nov. & 1 & 0.79 & Narrow \\
Amalda allaryi & 3 & $0.84-1.02$ (mean 0.92) & Very narrow \\
Amalda fuscolingua & 5 & $0.92-1.06(0.98)$ & Very narrow \\
Amalda coriolis & 5 & $0.95-1.13$ (mean 1.06) & Very narrow \\
Amalda monilifera & 1 & 0.65 & Very narrow \\
\hline
\end{tabular}

in Gemmel et al. (2020) and our trees, A. bellonarum occupies a basal position in the first offshoot in the datasets analyzed. Kilburn \& Bouchet (1988: 292) concluded that it "closely resembles (in miniature) its probable sister-species A. rosea (Macpherson, 1956) of the Queensland and New South Wales littoral" and that "Amalda rosea, together with a number of similar Australian species, is generally referred to [the] subgenus Alocospira, but probably belongs (with A. bellonarum) to an unnamed group". The isolated position of the species as revealed by molecular data is concordant with this conclusion, but it is premature to propose any change to its subgeneric classification.

We have observed that radular morphology is poorly correlated with shell characters or with species phylogeny, and similar radulae can be found in distantly related species, as in A. hilgendorfi and A. hayashii. The intraspecific variability of the radula morphology can be high, as demonstrated for species in which multiple radulae have been examined, e. g., A. hilgendorfi (Fig. 7A-G) or A. hayashii (Fig. 20F-I).

The radula in species of Amalda (Figs 7, 13, 20) is not very variable in comparison with species of Ancilla (Kantor et al. 2017: fig. 13), a fact probably reflecting a lower genetic variability in Amalda. The lateral teeth are very similar in most species, simple hook-shaped, while central teeth are more variable. Ponder (1968) illustrated the radulae of a number of species of Amalda, including the type species of two nominal subgenera - Baryspira P. Fischer, 1883 (Ancillaria australis G.B. Sowerby I, 1830) and Gracilispira Olsson, 1956 (Ancillaria novaezelandiae G.B. Sowerby II, 1859). The type species of Alocospira Cossmann, 1899 (Ancillaria papillata Tate, 1889) is fossil, but the radulae of two Recent species, attributed to the subgenus by Ponder (1968) - A. (Alocospira) marginata (Lamarck, 1811) and A. (Alocospira) oblonga G.B. Sowerby I, 1830 - were also illustrated.

Among our species, A. hilgendorf, A. miriky sp. nov. and A. aureomarginata form a supported molecular subclade and have radulae somewhat similar to those illustrated for Baryspira (Fig. 7A-J). The radulae of Baryspira and Alocospira, as illustrated by Ponder (1968), are also quite similar. The species forming the subclade that includes $A$. alabaster sp. nov., A. fuscolingua, A. allaryi and A. montrouzieri also possess rather similar radulae (Fig. 13). They are characterized by central teeth with rather narrow, strongly serrated lateral flaps and relatively large cusps, also usually with serrated edges. Kilburn \& Bouchet (1988: 281) hypothesized that "The conspicuously cyrtoconoid spire (of A. montrouzieri), 
which gives the shell an elongately pupiform shape, is characteristic of typical members of the subgenus Alocospira Cossmann, 1899". The radulae of A. montrouzieri and closely related species, however, differ markedly from representatives of A. (Alocospira) as illustrated by Ponder (1968: figs 26-27). Most divergent of all studied species is the radula of A. monilifera (Fig. 18B-E), which has practically multicuspid central teeth and differs from other species by its subtriangular, rather than hook-shaped, lateral teeth. Its radula is, however, similar to those illustrated for the type of Gracilispira (Ponder 1968: figs 24-25). A. monilifera was classified in Amalda (Gracilispira) by Gratecap (2016a).

\section{Acknowledgements}

Specimens were obtained during research cruises and expeditions organized by the MNHN and ProNatura International as part of the Our Planet Reviewed program, and by the MNHN and the Institut de Recherche pour le Développement as part of the Tropical Deep-Sea Benthos program (TERRASSES, EXBODI, EBISCO, KANACONO, KANADEEP 1, NORFOLK 2, SALOMON 2, SALOMONBOA 3, BIOPAPUA, PAPUANIUGINI, MADEEP, KAVIENG 2014, CONCALIS, PANGLAO 2005, NANHAI 2014, ZHONGSHA 2015, MIRIKY), and we are grateful to numerous cruise leaders and co-PIs: Wei-Jen Chen, Laure Corbari, Stephane Hourdez, Ludivina Labe, Peter Kee Lin Ng, Karine Olu-Le Roy, Nicolas Puillandre, Bertrand Richer de Forges and Sarah Samadi. All expeditions operated under the regulations then in force in the countries in question and satisfy the conditions set by the Nagoya Protocol for access to genetic resources. Further specimens were obtained in Mozambique during the INHACA 2011 expedition (with Universidade Eduardo Mondlane through Jose Rosado), in Australia during WESTERN AUSTRALIA 2011 (with the Western Australian Museum through Hugh Morrison), and in Japan through the courtesy of Mr Hirosuke Oshikata. We are especially grateful to our colleagues Marie-Catherine Boisselier, Julien Brisset, Barbara Buge, Virginie Héros, and Pierre Lozouet for companionship at sea and access to crucial data. Jose Rosado greatly assisted in diving activities during collection of some crucial specimens. David Massemin kindly provided the photographs of live specimens of Amalda and of the shell of $A$. herberti. We thank Josie Lambourdière and Dario Zuccon for their molecular work on old voucher specimens. Sofia Zvonareva assisted with photography. The study was conducted using Joint Usage Center "Instrumental methods in ecology" at the IEE RAS. We thank A. Neretina and A. Nekrasov for their friendly and helpful assistance with the SEM facilities. Last but not least we want to thnk the reviewers for very meticulous work and valuable comments. We acknowledge all the partners that have financially supported this work: (1) the Consortium National de Recherche en Génomique; (2) the ANR grant "Bioneocal" (PI: Philippe Grandcolas); (3) the Service de Systématique Moléculaire (UMS2700 MNHN-CNRS); (4) the project "Macrophylogeny of Life" (PI: Guillaume Lecointre), part of agreement no. 2005/67 between Genoscope and MNHN; (5) the ATM Barcode (PIs: Sarah Samadi and Jean-Noël Labat); and (6) the network "Bibliothèque du Vivant" (BdV) funded by MNHN, CNRS, INRA and the Centre National de Séquençage.

The contribution of Yu.Kantor and A. Fedosov was supported by Russian Science Foundation (grant No. 16-14-10118-П, PI Yu. Kantor).

\section{References}

Bandelt H.-J., Forster P. \& Röhl A. 1999. Median-joining networks for inferring intraspecific phylogenies. Molecular Biology and Evolution 16: 37-48. https://doi.org/10.1093/oxfordjournals.molbev.a026036

Bouchet P. \& Kantor Yu. I. 2004. New Caledonia: the major center of biodiversity for volutomitrid molluscs (Mollusca: Neogastropoda: Volutomitridae). Systematics and Biodiversity 1: 467-502. https://doi.org/10.1017/s1477200003001282

Bozzetti L. 2007. Due nuove Amalda (Gastropoda: Hypsogastropoda: Olividae) dalla Nuova Caledonia. Malacologia Mostra Mondiale 56: 14-16. 
Cossignani T. 2013. Una nuova Amalda dalla Nuova Caledonia. Malacologia Mostra Mondiale 79: $25-26$.

Cossignani T. 2015. Amalda hilgendorfi vezzaroi nuova ssp. Malacologia Mostra Mondiale 89: 24-25.

Cossmann M. 1899. Essais de paléoconchologie comparée. Vol. 3. Chez l'auteur et Comptoir géologique, Paris.

Fedosov A., Puillandre N., Kantor Yu. \& Bouchet P. 2015. Phylogeny and systematics of mitriform gastropods (Mollusca: Gastropoda: Neogastropoda). Zoological Journal of the Linnean Society 175: 336-359. https://doi.org/10.1111/zoj.12278

Folmer O., Black M., Hoeh W., Lutz R. \& Vrijenhoek R. 1994. DNA primers for amplification of mitochondrial cytochrome c oxidase subunit I from diverse metazoan invertebrates. Molecular Marine Biology and Biotechnology 3: 294-299.

Galindo L.A., Puillandre N., Strong E.E. \& Bouchet P. 2014. Using microwaves to prepare gastropods for DNA barcoding. Molecular Ecology Resources 14: 700-705. https://doi.org/10.1111/1755-0998.12231

Gemmel M.R. Trewick S.A., Hills S.F.K. \& Morgan-Richards M. 2020. Phylogenetic topology and timing of New Zealand olive shells are consistent with punctuated equilibrium. Journal of Zoological Systematics and Evolutionary Research 58: 209-220. https://doi.org/10.1111/jzs.12342

Gratecap D. 2012. Le genre Amalda en Afrique australe. Xenophora 140: 19-29.

Gratecap D. 2014. Le genre Amalda en Nouvelle-Calédonie. Xenophora 146: 13-20.

Gratecap D. 2016a. Le genre Amalda en Australie. Xenophora 155: 13-20.

Gratecap D. 2016b. Le genre Amalda dans l'Océan Indien et le Pacifique ouest. Xenophora 156: 4-15.

Hall T. 1999. BioEdit: a user friendly biological sequence alignment editor and analysis program for Windows 95/98 NT. Nucleic Acids Symposium Series 41: 95-98.

Hart M. 1995. Review of the genus Amalda from New Zealand with a description of a new species and the elevation of another subspecies to full species status. World Shells 13: 82-88.

Huelsenbeck J.P. \& Ronquist F. 2001. MrBayes: bayesian inference of phylogeny. Bioinformatics 17, 754-755. https://doi.org/10.1093/bioinformatics/17.8.754

Kantor Yu.I., Fedosov A.E., Puillandre N. \& Bouchet P. 2016. Integrative taxonomy approach to IndoPacific Olividae: new species revealed by molecular and morphological data. Ruthenica, Russian Malacological Journal 26: 123-144.

Kantor Yu.I., Fedosov A.E., Puillandre N., Bonillo C. \& Bouchet P. 2017. Returning to the roots: morphology, molecular phylogeny and classification of the Olivoidea (Gastropoda: Neogastropoda). Zoological Journal of the Linnean Society 180: 493-541. https://doi.org/10.1093/zoolinnean/zlw003

Katoh K. \& Toh H. 2010. Parallelization of the MAFFT multiple sequence alignment program. Bioinformatics 26: 1899-1900. https://doi.org/10.1093/bioinformatics/btq224

Katoh K., Rozewicki J. \& Yamada K.D. 2019. MAFFT online service: multiple sequence alignment, interactive sequence choice and visualization. Briefings in Bioinformatics 20: 11601166. https://doi.org/10.1093/bib/bbx108

Kilburn R.N. 1996. Two new species of Amalda from the Saya de Malha Bank. Molluscan Research 17: $21-25$.

Kilburn R.N. \& Bouchet P. 1988. The genus Amalda in New Caledonia (Mollusca, Gastropoda, Olividae, Ancillinae). Bulletin du Muséum national d'histoire naturelle, sér. 4, 10, section A 2: 277-300. 
Kira T. 1959. Coloured illustrations of the shells of Japan. Enlarged and revised edition. Hoikusha, Osaka.

Kira T. 1962. Shells of the Western Pacific in Color. Hoikusha, Osaka.

Kuroda T., Habe T. \& Oyama K. 1971. The Sea Shells of Sagami Bay, collected by His Majesty the Emperor of Japan. Maruzen,Tokyo.

Martens E. von. 1897. Conchologischer Miscellen, Part 2. Archiv fiir Naturgeschichte 63: 157-180, pls $15-17$.

Miller M.A., Pfeiffer W. \& Schwartz T. 2010. Creating the CIPRES Science Gateway for inference of large phylogenetic trees. Proceedings of the Gateway Computing Environments Workshop (GCE), 14 Nov. 2010, New Orleans, LA: 1-8.

Ninomiya T. 1988. A new subgenus and five new species of the Ancillinae (Gastropoda: Olividae) from Southwestern Australia, Japan and Taiwan. Venus 47: 141-153.

Ninomiya T. 1990. A new subgenus and five new species of the Ancillinae (Gastropoda: Olividae) from Australia. Venus 49: 69-82.

Okutani T. 2000. (ed.) Marine Mollusks in Japan. Tokai Uniersity. Press, Tokyo.

Ponder W.F. 1968. Nomenclatural notes on some New Zealand rachiglossan gastropods with descriptions of five new species. Records of the Dominion Museum 6: 29-47.

Poppe G.T. 2008. Philippine Marine Molluscs. Vol. 2. Conchbooks, Hackenheim.

Powell A.W.B. 1967. Mollusca of the Kermadec Islands: Part 2. Records of the Auckland Institute and Museum 6: 197-199.

Puillandre N., Lambert A., Brouillet S. \& Achaz G. 2012. ABGD, automatic barcode gap discovery for primary species delimitation. Molecular Ecology 21: 1864-1877.

https://doi.org/10.1111/j.1365-294X.2011.05239.x

Rambaut A., Suchard M.A., Xie D. \& Drummond A.J. 2014. Tracer v1.4.

Available from http://beast.bio.ed.ac.uk/Tracer [accessed 22 Feb. 2020].

Reeve L.A. 1864. Monograph of the Genus Ancillaria. In: Conchologia Iconica, 15. London, Reeve. Available from https://www.biodiversitylibrary.org/page/10972403 [accessed 29 Jul. 2020].

Rosenberg G. 2009. Malacolog 4.1.1: A Database of Western Atlantic Marine Mollusca. [WWW database (version 4.1.1)] Available from http://www.malacolog.org/ [accessed 22 Feb. 2020].

Souverbie S.M. 1860a. Descriptions d'espèces nouvelles de l'Archipel calédonien. Journal de Conchyliologie 8: 123-126, 204-207.

Souverbie S.M. 1860b. Descriptions d'espèces nouvelles de l'Archipel calédonien. Journal de Conchyliologie 8: 311-326, pl. 11.

Sowerby III G.B. 1897. Appendix to Marine Shells of South Africa : a Catalogue of all the Known Species with References to Figures in Various Works, Descriptions of New Species, and Figures of such as are New, Little Known, or hitherto Unfigured. G.B. Sowerby, London.

Stamatakis A. 2014. RAxML Version 8: A tool for phylogenetic analysis and post-analysis of large phylogenies. Bioinformatics 30: 1312-1313. https://doi.org/10.1093/bioinformatics/btu033

Taki I. \& Oyama K. 1954. Matajiro Yokoyama's the Pliocene and later faunas from the Kwanto Region in Japan. Palaeontological Society of Japan Special Papers 2: 1-68. 
Tamura K., Peterson D., Peterson N., Stecher G., Nei M. \& Kumar S. 2011. MEGA5: Molecular Evolutionary Genetics Analysis using maximum likelihood, evolutionary distance, and maximum parsimony methods. Molecular Biology and Evolution 28: 2731-2739.

https://doi.org/10.1093/molbev/msr121

Tsuchida E. 2017. Family Olivellidae. In: Okutani T. (ed.) Marine Mollusks in Japan, ${ }^{\text {nd }}$ Edition, Vol. 2: 995-997. Tokai University Press, Tokyo.

van Pel P.L. 1989. Una nuova sottospecie del genere Amalda del Mar di Arafura. A new subspecies of the genus Amalda from the Arafura Sea (Gastropoda: Olividae). La Conchiglia 238-241: 13-15.

Voskuil R.P.A. 1991. The recent species of the genus Eburna Lamarck, 1801. Vita Marina 41: 49-55.

Voskuil R. et al. 2011. The Olividae and Olivellidae ScratchPad - the electronic catalogue of olivid diversity. Available from http://olivirv.myspecies.info/ [accessed 2 Jun. 2020].

Wilson B. 1994. Australian Marine Shells. Prosobranch Gastropods. Part Two (Neogastropoda). Odyssey Publishing, Hong Kong.

Yokoyama M. 1922. Fossils from the Upper Musashino of Kazusa and Shimosa. Journal of the College of Science, Imperial University, Tokyo 44: 1-200.

Manuscript received: 24 February 2020

Manuscript accepted: 18 July 2020

Published on: 21 August 2020

Topic editor: Rudy Jocqué

Section editor: Thierry Backeljau

Desk editor: Kristiaan Hoedemakers

Printed versions of all papers are also deposited in the libraries of the institutes that are members of the EJT consortium: Muséum national d'histoire naturelle, Paris, France; Meise Botanic Garden, Belgium; Royal Museum for Central Africa, Tervuren, Belgium; Royal Belgian Institute of Natural Sciences, Brussels, Belgium; Natural History Museum of Denmark, Copenhagen, Denmark; Naturalis Biodiversity Center, Leiden, the Netherlands; Museo Nacional de Ciencias Naturales-CSIC, Madrid, Spain; Real Jardín Botánico de Madrid CSIC, Spain; Zoological Research Museum Alexander Koenig, Bonn, Germany; National Museum, Prague, Czech Republic. 